ANÁLISE DE SIGNIFICÂNCIA E CARACTERIZAÇÃO DE FONTES ESTACIONÁRIAS INDIVIDUALIZADAS VISANDO O MONITORAMENTO ATMOSFÉRICO NÃO RADIOLÓGICO NO CAMPUS IPEN/CNEN-SP

CAMILA FERNANDA ROCHA TELES TANZILLO SANTOS

Dissertação apresentada como parte dos requisitos para obtenção do Grau de Mestre em Ciências na Área de Tecnologia Nuclear Materiais

Orientadora:

Profa. Dra. Maria Aparecida Faustino Pires 


\section{INSTITUTO DE PESQUISAS ENERGETICAS E NUCLEARES}

Autarquia associada à Universidade de São Paulo

Análise de significância e caracterização de fontes estacionárias individualizadas visando o monitoramento atmosférico não radiológico no campus IPEN/CNEN-SP

\section{CAMILA FERNANDA ROCHA TELES TANZILLO SANTOS}

Dissertação apresentada como parte dos requisitos para obtenção do Grau de Mestre em Ciências na Área de Tecnologia Nuclear - Materiais

Orientadora: Profa. Dra. Maria Aparecida Faustino Pires

Versão Corrigida

Versão Original disponível no IPEN

São Paulo

2017 
Aos meus pais Silvia e Paulo, meus alicerces, por toda a dedicação, incentivo, educação e amor que recebi,

Aos meus irmãos Thiego, Carolina e João, que sempre me apoiaram nos momentos de fraquezas e vitórias. 


\section{AGRADECIMENTOS}

Primeiramente a Deus, que permitiu que tudo isso acontecesse, por ter me dado força, sabedoria e paciência para superar as dificuldades, por ser meu melhor ouvinte.

Aos meus pais, Silvia Fernanda e Paulo Murillo, que são tudo pra mim, por todo amor, apoio, palavra de carinho e, principalmente, por acreditarem em mim quando às vezes nem eu mesma acreditei.

Aos meus queridos e amados irmãos, Thiego Murillo, Ana Carolina e João Victtor, por serem meus melhores amigos, por me incentivarem, me inspirarem e fazerem eu me sentir especial.

À Dra. Maria Aparecida Faustino Pires, pela orientação, incentivo e confiança incutida para que conduzisse este trabalho.

À Dra. Marycel Elena Barboza Cotrim, pela contribuição para a realização deste trabalho.

Ao Instituto de Pesquisas Energéticas e Nucleares, IPEN-CNEN/SP, pela bolsa concedida.

À CNEN e ao Centro de Química e Meio Ambiente, CQMA, pela oportunidade de desenvolver este trabalho.

À Fundação Jorge Duprat Figueiredo de Segurança e Medicina do Trabalho FUNDACENTRO, pela colaboração no projeto de pesquisa.

Ao Dr. Walter dos Reis Pereira Filho, por ser sempre solícito e pela contribuição neste trabalho.

À amiga Tatiane Bernardino de Seixas Carvalho da Silva, pela amizade, parceria, paciência e pelas horas que ficamos desenvolvendo o projeto.

Aos amigos que fiz no mestrado, Adriana Kuchinski, Caio Miranda, Joana Maziero, 
Joyce Marques, Kelme Cardoso, Lucas Grosche, Mainara Faustino, Sâmia Maracaipe e Thamiris Stellato, por estarem presentes durante todo o curso, pela companhia e por serem meus amigos em todos os momentos.

Aos amigos Tereza Salvetti, Regiane Martins e Ricardo Smith, por todo apoio e ombro amigo.

Aos funcionários e alunos do CQMA, muito obrigada por toda ajuda técnica e pela convivência.

À minha avó Mercedes e às minhas tias Ayres Regina, Fátima Antônia e Maria de Lourdes, por cada ligação, pelos sábios conselhos e por todo amor.

À minha avó Clara Tanzillo,ao meu avô Paulo Murillo in memoriam, à minha bisavó Mafalda Sbrana in memoriam e à minha tia Glaucia Regina, por sempre estarem presentes, por toda ajuda, por torcerem por mim e por cada conselho.

Ao meu cunhado Luiz André, por ser meu ombro amigo, confidente nos melhores e piores dias.

Às amigas Carla Euzébio e Laura Seemann, aos amigos Eddy Bruno e Henrique Delfino, que se tornaram parte da minha família, dividindo os momentos felizes e os nem tanto.

Ao José Roberto Monteiro Salvador, por ter sido fundamental na conclusão deste trabalho, me incentivando, por todo carinho e preocupação.

Foram tantas as pessoas que cruzaram meu caminho e que me ajudaram nessa trajetória, que eu só tenho a agradecer por todo apoio e carinho.

Muito obrigada! 
"Não é o mais forte que sobrevive, nem o mais inteligente, mas o que melhor se adapta às mudanças" 


\title{
ANÁLISE DE SIGNIFICÂNCIA E CARACTERIZAÇÃO DE FONTES ESTACIONÁRIAS INDIVIDUALIZADAS VISANDO O MONITORAMENTO ATMOSFÉRICO NÃO RADIOLÓGICO NO CAMPUS DO IPEN/CNEN-SP
}

\author{
Camila Fernanda Rocha Teles Tanzillo Santos
}

\section{RESUMO}

Devido ao compromisso com a melhoria do meio ambiente, aliado às crescentes exigências dos órgãos ambientais, e a necessidade de identificar a contribuição de cada atividade/processo desenvolvido em institutos de pesquisas, quanto ao impacto destes à qualidade do ar, este trabalho teve a finalidade de desenvolver um modelo de inventário e aplicar uma metodologia de cálculo, que permita estimar a emissão de poluentes atmosféricos, decorrentes das atividades dos centros de pesquisa e desenvolvimento do Instituto de Pesquisas Energéticas e Nucleares (IPEN/CNEN-SP). O estudo foi motivado pela ausência de metodologias de cálculo de emissões atmosféricas específicas para fontes fixas como capelas químicas de exaustão e da necessidade em atender as condicionantes estabelecidas no licenciamento ambiental da instituição. Para a elaboração dos cálculos foram adotados os fatores de emissão e a equação descrita na AP-42 da EPA- Environmental Protection Agency. Foram utilizadas como abordagens de cálculo de emissões:

a) Mensuração direta (por meio do inventário de emissões atmosféricas); e b) Estimativa de emissões (utilizando estimativa da taxa de emissão calculada a partir do fator de emissão apropriado). O estudo foi detalhadamente realizado tendo como base inicial o inventário e o modelo de estimativa de emissão atmosférica das fontes fixas aplicado no Centro de Química e Meio Ambiente (CQMA). Cabe ressaltar que o monitoramento online da qualidade do ar no campus é realizado em estação fixa, parceria IPEN CETESB, na estação CETESB Cid. Universitária - IPEN - USP. O estudo possibilitou estabelecer, de forma efetiva, o Programa de Monitoramento e Controle de Emissões 
Atmosféricas (PMEA - IPEN), podendo servir de modelo para outras instituições de Pesquisa, Desenvolvimento \& Inovação. Como produto final obteve-se um inventário de emissões atmosféricas de fontes fixas da instituição, a taxa de emissão de poluentes, bem como a concentração de poluentes emitidos. A estimativa das emissões não ultrapassou os limites dispostos na legislação em âmbito nacional e estadual.

Palavras-chave: Inventário, emissão de poluentes atmosféricos, AP- 42, estimativa de emissões, institutos de pesquisa, desenvolvimento e inovação. 


\title{
ANALYSIS OF SIGNIFICANCE AND CHARACTERIZATION OF INDIVIDUALIZED STATIONARY SOURCES FOR NON-RADIOLOGICAL ATMOSPHERIC MONITORING AT CAMPUS OF IPEN / CNEN-SP
}

\author{
Camila Fernanda Rocha Teles Tanzillo Santos
}

\begin{abstract}
Atmospheric Emission Factors and Significance Analysis applied to the Air Quality Management in the IPEN / CNEN-SP Campus due to the commitment to improve the environment, combined with the increasing demands of environmental agencies, and the need to identify the contribution of each activity / process developed in research institutes, as well as the impact of these on the air quality, this work aims to develop an inventory model and apply a methodology of calculation for measuring the emission of atmospheric pollutants, arising from the activities of the research and development centers of the Nuclear and Energy Research Institute (IPEN / CNEN-SP). The study was motivated by the absence of atmospheric emission calculation methodologies specific to stationary sources, such as fume hoods. For preparation of the calculations, the emission factors and the equation described in the AP-42 EPAEnvironmental Protection Agency were adopted. The emission calculation methods used were: a) Direct measurement (through the inventory of air emissions); and b) Emissions estimate (using the emission rate estimate calculated from the appropriate emission factor). The study was carried out in detail, based on the inventory and model of atmospheric emission of fixed sources applied at the Chemistry and Environment Center (CQMA). It should be noted that online monitoring of air quality on campus is carried out at a fixed station, IPEN CETESB partnership, at CETESB Cid station. University - IPEN USP. The study has made it possible to establish, in an effective way, the Atmospheric Emission Monitoring and Control Program (PMEA - IPEN), which
\end{abstract}


could serve as a model for other Research, Development and Innovation institutions. The final product was an inventory of atmospheric emissions from fixed sources of the institution, the emission rate of pollutants, as well as the concentration of pollutants emitted. The estimation of the emissions did not exceed the limits established in the national legislation and state level.

Keywords: Inventory, Emission of atmospheric pollutants, AP-42, Emissions estimate, research, development and innovation institutions. 


\section{SUMÁRIO}

1 INTRODUÇÃO

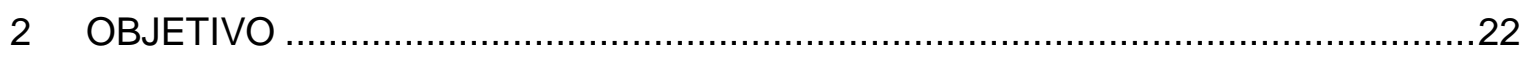

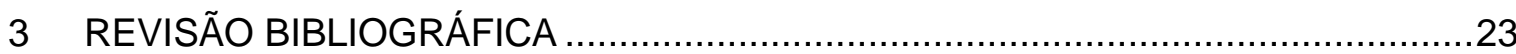

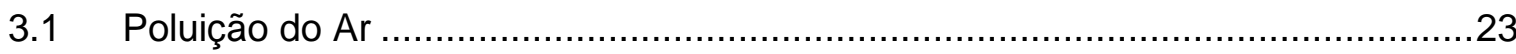

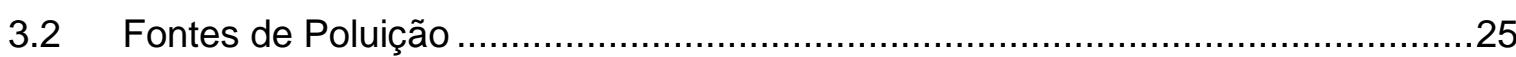

3.3 Inventário de Emissões Atmosféricas …………………………………........29

3.4 Métodos de Estimativa de Emissão/Potencial Poluidor ........................................31

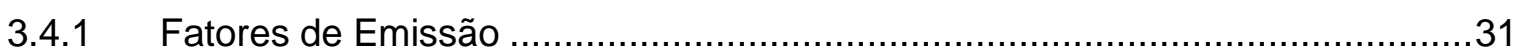

3.4.2 Modelos de Emissões Atmosféricas ............................................................32

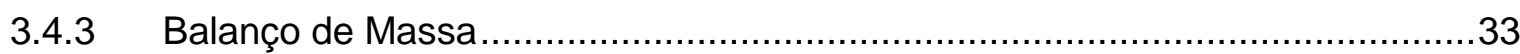

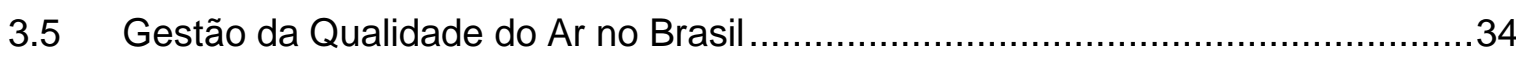

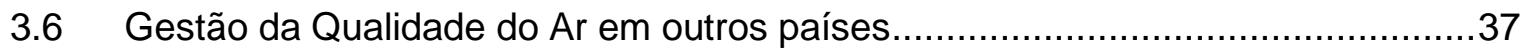

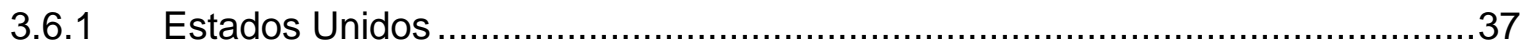

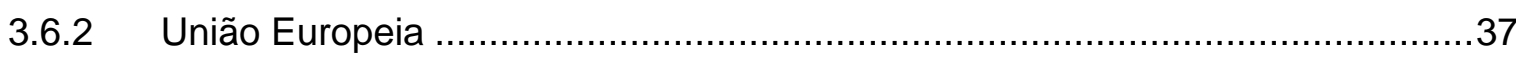

3.7 Critérios e Procedimentos para a revisão dos Padrões de Qualidade do $\mathrm{Ar}$.........38

3.8 Padrões de Qualidade do Ar no Brasil ...........................................................39

3.9 Padrões de Qualidade do Ar nos Estados Unidos ............................................42

3.10 Padrões de Qualidade do Ar na União Europeia................................................4

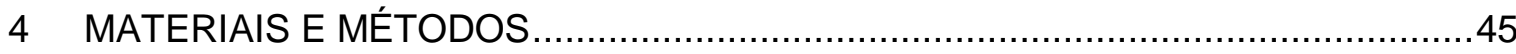

4.1 Domínio do inventário (Caracterização da Área de Estudo) .................................45

4.2 Definição da abordagem utilizada .................................................................51

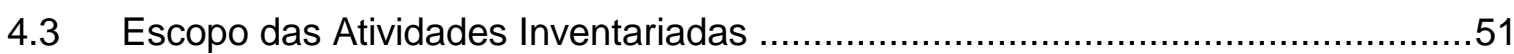

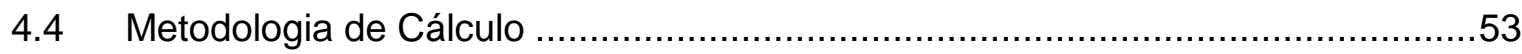

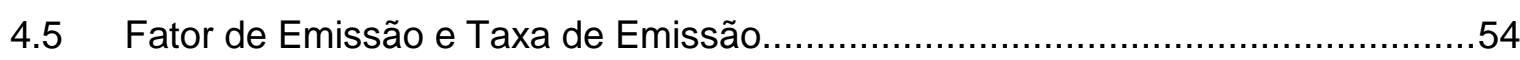

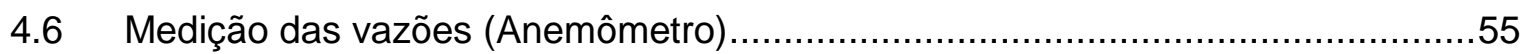

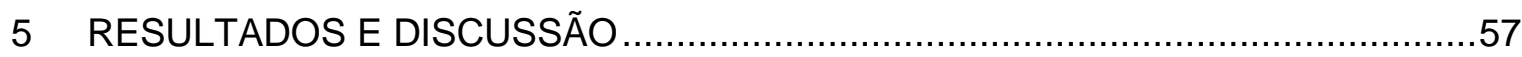

5.1 Monitoramento contínuo da qualidade do ar do campus.....................................57

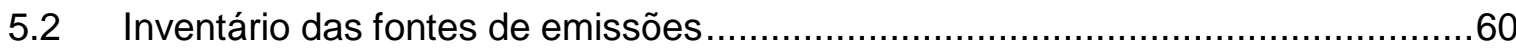

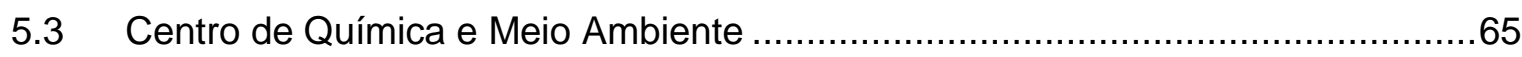

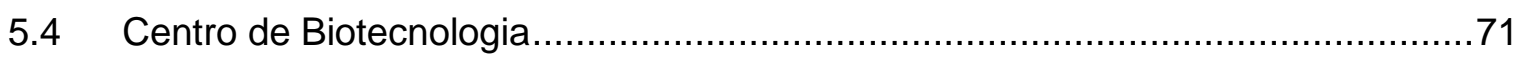

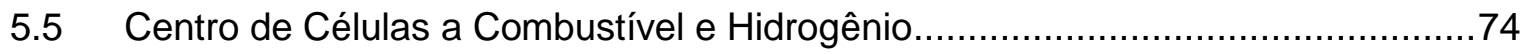

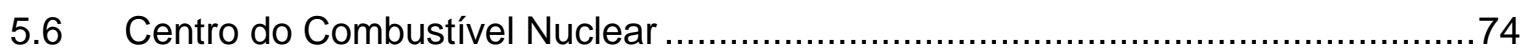

5.7 Centro de Ciência e Tecnologia dos Materiais ..................................................76

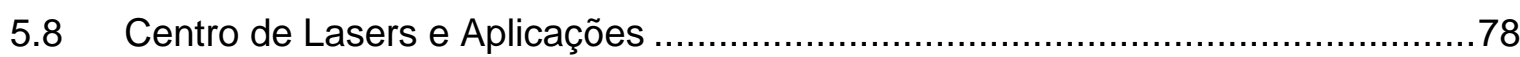

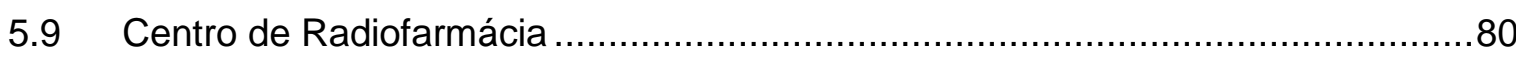

Figura 15 - Distribuição de fontes fixas no Centro de Radiofarmácia..............................83 


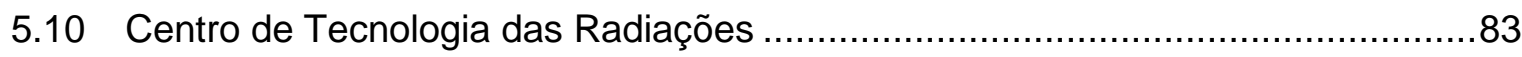

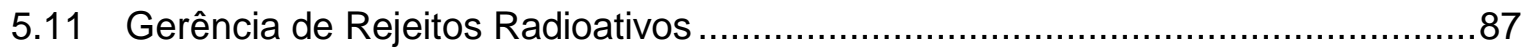

5.12 Gerência de Metrologia das Radiações ......................................................... 88

6 CÁLCULO DAS TAXAS DE EMISSÕES ....................................................90

6.1 Comparação dos valores com Normas e Padrões Estabelecidos .........................92

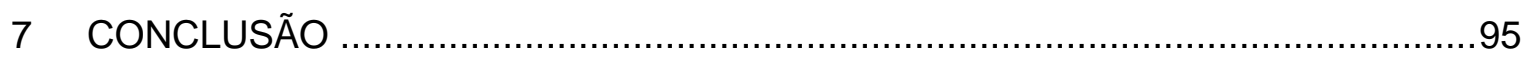

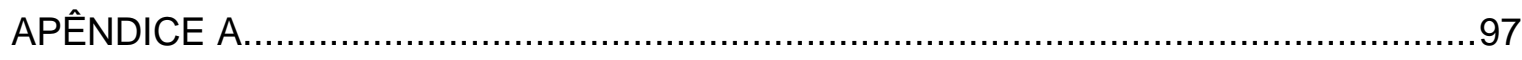

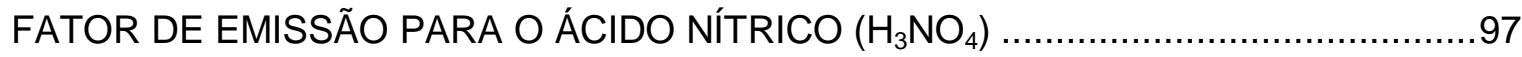

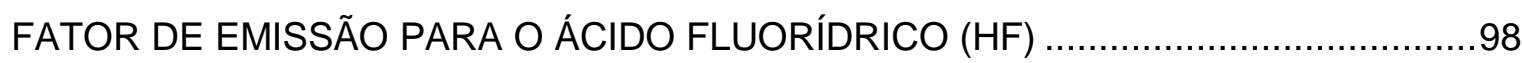

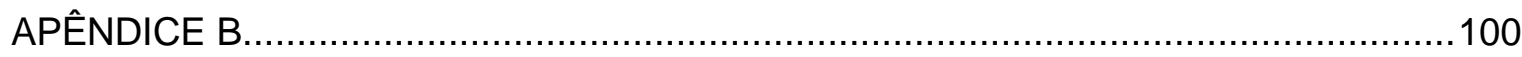

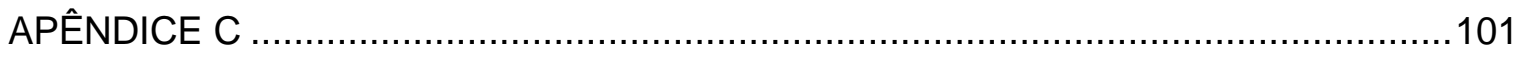

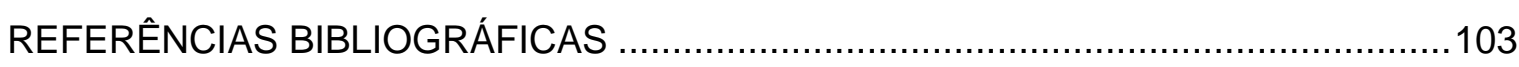




\section{LISTA DE TABELAS}

Tabela 1 Principais poluentes atmosféricos, suas fontes e seus principais

efeitos na saúde e no meio ambiente.

Tabela 2 Instrumentos Legais para Controle da Poluição Atmosférica em nível Federal e Estadual.

Tabela 3 Padrões estaduais de qualidade do ar.

Tabela 4 Padrões nacionais de qualidade do ar adotados no EUA.

Tabela 5 Padrões Europeus de Qualidade do Ar.

Tabela 6 Controle operacional quanto aos aspectos ambientais do IPEN.

Tabela 7 Programas de Controle Ambiental, segurança, prevenção e minimização de impacto ambiental.

Tabela 8 Parâmetros e frequência de monitoramento de emissões atmosféricas para o Estado de São Paulo definidos para a indústria química.

Tabela 9 Inventário das principais atividades, realizado por centros e processos produtivos, visando à identificação das fontes fixas de emissão atmosférica no IPEN.

Tabela 10 Modelo do levantamento das informações das fontes fixas de poluição.

Tabela 11 Inventário de reagentes consumidos ( $\mathrm{L}$ mês $\left.{ }^{-1}\right)$ nos 09 laboratórios do Centro de Química e Meio Ambiente (Período 2013/2017).

Tabela 12 Inventário por reagentes utilizados no CB.

Tabela 13 Inventário por reagentes utilizados no $\mathrm{CCCH}$.

Tabela 14 Inventário por reagentes utilizados no CCN.

Tabela 15 Inventário por reagentes utilizados no CCTM.

Tabela 16 Inventário por reagentes utilizados no CLA.

Tabela 17 Inventário por reagentes utilizados no CR.

Tabela 18 Inventário por reagentes utilizados no CTR.

Tabela 19 Inventário por reagentes utilizados na GRR.

Tabela 20 Inventário por reagentes utilizados na GRR.

Tabela 21 Descrição e densidade dos reagentes inventariados. 
Tabela 22 Fatores de emissão descritos na AP-42.

Tabela 23 Taxa de Emissão dos poluentes emitidos nos laboratórios 91 do CQMA.

Tabela 25 Concentração de $\mathrm{NO}_{\mathrm{x}}$ e $\mathrm{SO}_{\mathrm{x}}$ por centro de pesquisa do IPEN. 


\section{LISTA DE FIGURAS}

Figura 1 Resumo dos padrões de emissão e legislações vigentes. 42

Figura 2 Localização do IPEN no campus da USP.

Figura 3 Organograma do Instituto de Pesquisa Energéticas e 47 Nucleares - IPEN.

Figura 4 Vista Aérea do Instituto de Pesquisa Energéticas e Nucleares IPEN; localização da estação de monitoramento da CETESB - IPEN/USP.

Figura 5 Etapas estabelecidas para realização do inventário de emissões atmosféricas.

Figura 6 Foto representativa do Anemômetro e sondas (Anemômetro testo 435).

Figura 7 Medida diária do sistema de auto monitoramento realizado na estação da Cid. Universitária -USP-IPEN.

Figura 8 Mapa da qualidade do ar - rede automática - em destaque rede Cidade Universitária - USP-IPEN.

Figura 9 Evolução das Concentrações médias anuais de $\mathrm{NO}_{2}$ na RMSP.

Figura 10 Distribuição de fontes fixas por prédio que compõe o

Centro de Química e em Meio Ambiente.

Figura 11 Inventário de reagentes consumidos nos laboratórios do CQMA.

Figura 12 Distribuição de fontes fixas no Centro de Biotecnologia.

Figura 13 Distribuição de fontes fixas no Centro do Combustível Nucelar.

Figura 14 Distribuição de fontes fixas no Centro de Tecnologia dos Materiais.

Figura 15 Distribuição de fontes fixas no Centro de Lasers e Aplicações..

Figura 16 Distribuição de fontes fixas no Centro de Radiofarmácia.

Figura 17 Distribuição de fontes fixas no Centro de Tecnologia das Radiações. 
Figura 18 Distribuição de fontes fixas na Gerência de Rejeitos Radioativos

Figura 19 Distribuição de fontes fixas na Gerência de Metrologia das Radiações.

Figura 20 Valores médios de $\mathrm{NO}_{x}$ por hora determinados a partir da taxa de emissão atmosféricas das fontes fixas pertencentes aos Laboratórios dos Centros do Ipen comparação com legislação ambiental federal e estadual.

Figura 21 Valores médios de SOx por hora determinados a partir da taxa de emissão atmosféricas das fontes fixas pertencentes aos Laboratórios dos Centros do Ipen comparação com legislação ambiental federal e estadual. 


\section{INTRODUÇÃO}

A habilidade da sociedade em causar danos significativos ao meio ambiente é um fenômeno diretamente influenciado pelo crescimento demográfico e tecnológico. O homem primitivo, vivendo em menor número e fazendo uso somente ao necessário à sobrevivência, não alterou significativamente o ambiente.

A poluição atmosférica, entretanto, não é um processo recente e de inteira responsabilidade do homem, tendo a própria natureza se encarregado, durante milhares de anos, de participar ativamente deste processo com o lançamento de gases e materiais particulados originários de atividades vulcânicas e tempestades, dentre algumas fontes naturais de poluentes. A atividade antrópica, por sua vez, acaba por intensificar a poluição do ar com o lançamento contínuo de grandes quantidades de substâncias poluentes (Oliveira 1997).

Os poluentes se concentram na camada de ar mais próxima à superfície terrestre, a troposfera, zona onde ocorre a maioria dos fenômenos atmosféricos e o aparecimento de problemas ambientais, como, a chuva ácida e o aquecimento global. Nesta camada estão localizados também os gases de vital importância no equilíbrio térmico do planeta.

Enquanto não havia grandes avanços tecnológicos, a intervenção humana não representava significativa ameaça à atmosfera, que acionava seus mecanismos naturais de controle para manter o equilíbrio térmico do planeta.

A maior contribuição da carga de poluentes nas grandes metrópoles está associada ao setor de transportes e em seguida ao setor industrial, que assume importante contribuição nas regiões mais desenvolvidas de um país, quase sempre associadas à alta densidade demográfica (Pires, 2005).

Entre as influências antropogênicas, uma das mais importantes, relativa às alterações climáticas, está a emissão de gases de efeito estufa bem como as mudanças no uso da terra, com destaque a urbanização e a agricultura (Kalnay \& Cai, 2003). 
Segundo $05^{0}$ Relatório de Avaliação do clima, do Painel Intergovernamental de Mudanças Climáticas (IPCC), entre 2000 e 2010 as emissões cresceram mais rapidamente do que na década anterior, sobretudo em razão do aumento do uso de carvão para geração de energia. Hoje, a concentração de gases de efeito estufa (GEE) na atmosfera é a mais alta desde últimos 800 mil anos (IPCC, 2013).

Durante a Conferência do Clima, realizada em Paris em 2015, um dos relatórios apresentado pelas Nações Unidas destacou que as ações humanas são as maiores causadoras do fenômeno climático e a maior ameaça ao meio ambiente natural e aos direitos humanos de nosso tempo. (ONU, 2017).

A poluição do ar tornou-se um dos principais fatores que afetam a qualidade de vida da população e causa sérios danos ao meio ambiente (Wang, 2010; Guarieiro e Guarieiro, 2013).

Durante muito tempo, o desenvolvimento econômico decorrente da Revolução Industrial impediu que os problemas ambientais fossem levados em conta. Por ser uma atividade de alto impacto ambiental, surgiu uma crescente preocupação da sociedade e dos órgãos reguladores ambientais, devido ao elevado grau de risco à saúde das populações e de poluição ambiental. Antes da intensa fase regulatória mundial, as indústrias concentravam suas preocupações, excepcionalmente com a produção e os lucros. Medidas para proteger o meio ambiente, neste período, eram imperceptíveis, o que levou, mais tarde, a danos ambientais irreversíveis.

Segundo dados recentes sobre o tema (ONU, 2017), a mudança do clima é afetada pela dinâmica populacional e a mudanças climáticas afetam diretamente a capacidade de desenvolvimento dos países.

Ações de controle foram e estão sendo tomadas mundialmente, tais como, redução da emissão de gases de efeito estufa, legislações mais restritivas, a exigência do licenciamento ambiental e o monitoramento ambiental dos complexos industriais e seu entorno. O foco da emissão de gases de efeito estufa sempre aparece como relevante por ser considerado o principal vetor das mudanças climáticas, devendo cada setor incorporar a avaliação de seus riscos 
em suas atividades, desenvolvendo projetos com atuação coerente ao parâmetro de sustentabilidade.

"Tomar medidas urgentes para combater a mudança climática e seus impactos" está entre os Objetivos de Desenvolvimento Sustentável, ODS (ODS 13) propostos pela ONU, Organização das Nações Unidas, em seu relatório "O caminho para a dignidade até 2030: acabando com a pobreza, transformando todas as vidas e protegendo o planeta" (PNUD 2014, ONU, 2017).

Por definição, os Gases do efeito estufa (GEE) são substâncias gasosas que absorvem parte da radiação infravermelha, emitida principalmente pela superfície terrestre, e dificultam seu escape para o espaço. Isso impede que ocorra uma perda demasiada de calor para o espaço, mantendo a Terra aquecida. Os GEE emitidos por veículos incluem o dióxido de carbono, o metano, o dióxido de nitrogênio e os hidrofluorcarbonos (MMA, 2013).

No Brasil, os poluentes atmosféricos padronizados são: partículas totais em suspensão (PTS), fumaça (FMC), dióxido de enxofre $\left(\mathrm{SO}_{2}\right)$, partículas inaláveis $\left(\mathrm{MP}_{10}\right)$, monóxido de carbono $(\mathrm{CO})$, ozônio $\left(\mathrm{O}_{3}\right)$ e dióxido de nitrogênio $\left(\mathrm{NO}_{2}\right)$ (CONAMA, 2006; Lisboa e Kawano, 2007, CETESB, 2016).

Uma das ferramentas de controle da poluição é o gerenciamento da qualidade do ar que tem como instrumento o inventário de emissões atmosféricas, que segundo o European Environment Agency - EEA (2013) permite o monitoramento das emissões, a avaliação de potenciais impactos ambientais e a verificação do cumprimento de normas e padrões estabelecidos.

Segundo a Agência Ambiental dos Estados Unidos - USEPA, EPA (2001) os inventários de emissões de poluentes atmosféricos representam a compilação de dados e informações que permitem a caracterização das fontes de poluição no tempo e no espaço. Estes instrumentos contribuem nos processos de gestão ambiental, além de prover informação de grande relevância para as agências ambientais, governantes e órgãos gestores da qualidade do ar (IPCC, 2013; EPA, 2000).

Os inventários de emissões de poluentes atmosféricos de uma 
determinada região ou de um determinado empreendimento são fundamentais para o desenvolvimento de estudos científicos em programas de monitoramento e análise da qualidade do ar. Como exemplo, podem auxiliar na medição dos impactos dos diversos setores (energia; transporte, agricultura, indústrias químicas) sobre a qualidade do ar e na saúde, de modo a auxiliar no desenvolvimento de políticas públicas (EPA, 2000; EPA, 2011; IPCC, 2013; Kawashima et al., 2015).

As finalidades mais comuns para o uso do inventário de emissões atmosféricas incluem estudos da qualidade do ar, desenvolvimento estratégico de controle, monitoramento e modelagem de dispersão de emissões e licenciamento de instalações (EPA, 1997).

O inventário de emissões atmosféricas é um instrumento de política de gestão ambiental no tocante aos efluentes atmosféricos no qual consta um conjunto de informações referente ao processo onde as emissões são geradas, aos tipos de poluentes gerados e aos possíveis sistemas de controle. No Estado de São Paulo, por exemplo, a Companhia Ambiental do Estado de São Paulo - CETESB, orienta através da Decisão de Diretoria N 010/2010/P quanto à elaboração do inventário de fontes atmosféricas do Programa de Monitoramento de Emissões Atmosféricas - PMEA.

As estimativas de emissão são importantes para o desenvolvimento de estratégias, determinando a aplicabilidade e facilitando a elaboração de programas de controle, determinando os efeitos das fontes e as estratégias apropriadas de mitigação.

Informações da fonte que especificam a emissão são geralmente preferenciais para a estimativa da emissão, uma vez que é a melhor representação da emissão desta fonte. Entretanto, fontes individuais de uso não frequente e eventual podem não refletir a variabilidade das emissões no tempo. Assim, o fator de emissão pode ser frequentemente o melhor método para avaliar a estimativa das emissões, dentro de suas limitações (EPA, 2001).

Para a estimativa de emissões atmosféricas, a CETESB orienta que na ausência de dados de amostragem, as emissões podem ser estimadas por 
meio do emprego de fatores de emissão ou balanço de massa, sendo sugerido e referenciado que sejam utilizados os fatores de emissão da Agência Ambiental dos Estados Unidos - USEPA, constantes na publicação da EPA, "Emissions Factors \& AP 42, Compilation of Air Pollutant Emission Factors" disponível em http://www.epa.gov/ttn/chief/ap42/index.html.- AP 42.

Quanto ao controle das emissões de fontes fixas não há legislação específica em nível federal, estadual ou municipal, que fixe padrões ou limites para emissão de poluentes de dutos de exaustão em ambientes ocupacionais e dutos de exaustão do ar circulante em estufas de secagem e exaustores analíticos. Entretanto, há um grande esforço das instituições em nível estadual em promover a execução do inventário de fontes fixas e móveis (CETESB, 2009), apesar de não possuir obrigatoriedade em nível federal.

As principais exigências legais pertinentes no âmbito federal são: a) a resolução CONAMA no $03 / 90$, que estabelece os padrões nacionais de qualidade do ar; e b) a resolução CONAMA o 436/2011, que fixa os limites máximos de emissão de poluentes atmosféricos para fontes fixas. No âmbito estadual temos o Decreto Estadual № 59113/2013 que estabelece os padrões estaduais de qualidade do ar. No Brasil, o Ministério do Trabalho e Emprego (MTE, 1978) estabelece valores de exposição para ambientes de trabalho conforme a NR-15, anexos $n^{\circ} 11$ e 13-A, no que se refere aos agentes químicos e atividades e operações insalubres.

Este trabalho foi desenvolvido com a finalidade de avaliar e aplicar uma metodologia de cálculo, utilizando fatores de emissão, que permita estimar a emissão de poluentes de fontes fixas para a atmosfera, decorrentes das atividades não nucleares realizadas no Instituto de Pesquisas Energéticas e Nucleares - IPEN.

O estudo possibilitou identificar as emissões atmosféricas significativas de modo a facilitar o estabelecimento e implantação do programa de monitoramento e controle ambiental de emissões atmosféricas dentro do campus do IPEN. O IPEN é considerado uma instituição a pesquisa \& ensino, IES, cuja multidisciplinaridade das atividades do setor nuclear, tem conduzido a 
um amplo e variado programa de Pesquisa \& Desenvolvimento e Inovação (P\&D) em diversas outras áreas correlatas.

O compromisso com a melhoria do meio ambiente alinhado às crescentes demandas dos órgãos ambientais e a necessidade de atender as exigências estabelecidas entre o Instituto Brasileiro de Meio Ambiente e dos Recursos Naturais Renováveis - IBAMA e o IPEN (conforme os documentos: Termo de Ajustamento de Conduta, TAC-IBAMA, 2013 e as condicionantes da Licença de Operação do IPEN, N 1325/2016 (L.O), de 22/02/2016), possibilitou o estabelecimento de um diagnóstico ambiental, com a realização de um inventário das emissões atmosféricas de fontes fixas, identificando a contribuição de cada atividade/processo dentro do campus do IPEN quanto ao impacto à qualidade do ar.

Cabe salientar a Companhia Ambiental do Estado de São Paulo CETESB e o IPEN possuem uma parceria no programa de monitoramento atmosférico de São Paulo sendo realizado dentro do campus do IPEN. Esta estação de monitoramento on-line denominada IPEN-USP (http://www.cetesb.sp.gov.br/ar/qualidade-do-ar) foi instalada pelo IPEN em seu campus, coordenadas geográficas em UTM (Datum WGE 84): Longitude: 23K 322.680 E; Latitude: 7.392.709 S, com apoio do Centro de Química e Meio Ambiente, sendo gerida e mantida pela CETESB por meio de um Acordo de Mútua Cooperação Técnico - Científica, celebrado entre a CETESB e a CNENIPEN, desde 2002. Os resultados de monitoramento dessa estação também são utilizados para completar o monitoramento atmosférico no campus do IPEN. Os relatórios estão disponíveis online, com dados diários, podendo ser acessados no Boletim de Qualidade do Ar CETESB-RMSP. 


\section{OBJETIVO}

Este trabalho teve a finalidade de estabelecer estratégias para a gestão da qualidade do ar em empreendimentos de ensino, pesquisa e inovação preexistentes utilizando fatores de emissão como método de estimativa de emissões, a partir da realização de um inventário das emissões atmosféricas de fontes fixas. Como área estratégica o estudo foi direcionado para o campus do IPEN / CNEN - SP.

Para atingir o objetivo foram executadas as seguintes etapas:

- Realizar um levantamento bibliográfico das diversas metodologias relativas à estimativa de emissões atmosféricas;

- Realizar um levantamento das legislações nacionais e internacionais relacionadas a emissões atmosféricas;

- Realizar um inventário das fontes fixas (capela de exaustão de gases, dutos, exautores, etc.) e, consequentemente, um Inventário de Emissões Atmosféricas do IPEN englobando os processos produtivos e suas respectivas operações unitárias, juntamente com o detalhamento e caracterização das fontes geradoras;

- Identificar protocolos de emissões pertinentes aos processos identificados, ou seja, definição das rotinas de cálculos e identificação das informações necessárias para a estimativa das emissões;

- Realizar a aplicação dos protocolos e quantificar as emissões atmosféricas;

- Comparar as emissões com as normas e padrões estabelecidos. 


\section{REVISÃo BIBLIOGRÁFICA}

\subsection{Poluição do Ar}

Como assinalou Pires (2005), o conceito de poluição atmosférica inclui atividades humanas e/ou atividades naturais que levam à deterioração da qualidade original da atmosfera.

Poluição atmosférica pode ser definida como a presença de substâncias estranhas na atmosfera, resultantes da atividade humana ou de processos naturais, em concentrações suficientes para interferir direta ou indiretamente na saúde, segurança e bem-estar dos seres vivos (Pires, 2005; Cançado et at., 2006).

A Convenção da Comissão Econômica Europeia sobre a Poluição Atmosférica Transfronteiras, definiu o conceito de poluição atmosférica como a emissão de substâncias ou energia que resultem em efeitos deletérios de tal natureza que coloque em risco a saúde humana, prejudique os recursos biológicos, os ecossistemas e os bens materiais (UNECE, 1979).

De acordo com Gouveia, (1999), a poluição do ar é um problema para a grande proporção da população urbana mundial, cujas implicações na saúde têm sido até hoje subestimadas.

A Resolução CONAMA №. 3, de 28/06/1990, considera poluente atmosférico como:

"Qualquer forma de matéria ou energia com intensidade e em quantidade, concentração, tempo ou características em desacordo com os níveis estabelecidos, e que tornem ou possam tornar o ar impróprio, nocivo ou ofensivo à saúde, inconveniente ao bem-estar público, danoso aos materiais, à fauna e à flora ou prejudicial à segurança, ao uso e gozo da propriedade e às atividades normais da comunidade".

De acordo com o regulamento da Lei 997, de 31 de maio de 1976, 
que dispõe sobre o controle da poluição do meio ambiente no Estado de São Paulo, considera-se poluente toda e qualquer forma de matéria ou energia lançada ou liberada nas águas, no ar e no solo:

“l) Com intensidade, em quantidade e de concentração, em desacordo com os padrões de emissão estabelecidos neste Regulamento e normas dele decorrentes; II) com características e condições de lançamento ou liberação, em desacordo com os padrões de condicionamento e projeto estabelecidos nas mesmas prescrições; III) por fontes de poluição com características de localização e utilização em desacordo com os referidos padrões de condicionamento e projeto; IV) com intensidade, em quantidade e de concentração ou com características que, direta ou indiretamente tornem ou possam tornar ultrapassáveis os padrões de qualidade do Meio Ambiente estabelecidos neste Regulamento e normas dele decorrentes; V) que, independente de estarem enquadrados nos incisos anteriores, tornem ou possam tornar as águas, o ar ou o solo impróprios, nocivos ou ofensivos à saúde, inconvenientes ao bem estar público; danosos aos materiais, à fauna e à flora; prejudiciais à segurança, ao uso e gozo da propriedade, bem como às atividades normais da comunidade".

O problema da poluição do ar tem-se constituído numa das mais graves ameaças à qualidade de vida de seus habitantes. É um dos maiores problemas da atualidade, associada diretamente a efeitos negativos na saúde humana e o aumento contínuo das fontes poluidoras sem o devido controle tem cooperado na elevação de níveis de poluição atmosférica.

A Organização Mundial de Saúde - OMS considera que os poluentes atmosféricos são um dos 10 produtos químicos de maior preocupação para a saúde pública. As evidências científicas dos efeitos associados à poluição do ar estão bem estabelecidas na literatura, mas não há limite para "efeito zero" para contaminantes mais estudados $\left(\mathrm{PM}_{10} ; \mathrm{PM}_{2,5} ; \mathrm{NO}_{2} ; \mathrm{SO}_{2}\right.$ e $\left.\mathrm{O}_{3}\right)$. Estima-se que 
para cada aumento de $10 \mathrm{mg} / \mathrm{m}^{3}$ de $\mathrm{PM}_{10}$ há um aumento de $0,5 \%$ no risco de morte. Os padrões vigentes variam muito de país para país, e alguns não estabelecem limites para alguns parâmetros ou usam limites maiores do que os recomendados pelas diretrizes da OMS (Santos et al. 2016).

\subsection{Fontes de Poluição}

Um poluente pode ter diversas origens, nomeadas "fontes". Essas fontes podem se constituir em emissões diretas na atmosfera e podem ser de origem natural ou antropogênica. Para Pires (2005), fonte de poluição é um conceito amplo que pode ser definido, como:

1. Um local do qual escapam substâncias poluentes (chaminés, dutos, descargas de ar, etc);

2. Processos e/ou equipamentos de produção (caldeiras, fornos, linhas de produção, câmaras de combustão, etc);

3. Uma área ou conjunto de pontos e/ou processos e equipamentos numa região específica, capazes de liberar matéria ou energia para a atmosfera, tornando-a poluída.

De acordo com o Conselho Nacional do Meio Ambiente - CONAMA (CONAMA n 382, 2006; CONAMA n 436, 2011). Fonte de emissão ou fonte é qualquer processo ou atividade que libera poluentes para a atmosfera.

Segundo a (CETESB, 2015) são consideradas fontes de poluição do ar todas as obras, atividades, instalações, empreendimentos, processos, dispositivos móveis ou imóveis ou meios de transportes, que direta ou indiretamente causem ou possam causar poluição ao meio ambiente.

As diversas fontes de poluição podem ser classificadas da seguinte forma:

- Fontes Estacionárias ou fontes fixas: queimadas, processos industriais, queima de combustível em padarias, lavanderias, etc;

- Fontes Móveis: Todos os meios de transporte terrestre, aéreo e marítimo; 
- Fontes Naturais: Todos os processos naturais de emissão que ocorreram/ocorrem durante os milhares de anos, como as atividades vulcânicas, tempestades, liberação de hidrocarbonetos pelas plantas, a ação eólica, etc.

A poluição atmosférica causa vários efeitos prejudiciais sobre o bem estar e a saúde da população, sobre a vegetação, os animais, a atmosfera, as construções, etc.

Como ressaltou Cavalcanti (2010),

"Os efeitos causados pela concentração de poluentes do ar podem se manifestar na saúde, no bem estar da população, na vegetação e na fauna, sobre os materiais, sobre as propriedades da atmosfera, passando pela redução da visibilidade, alteração da acidez das águas da chuva (chuva ácida), mudanças climáticas (alteração do regime de chuvas, aumento do nível dos oceanos etc.), aumento do efeito estufa e modificação da intensidade da radiação solar (aumento da incidência de radiação ultravioleta sobre a Terra, causado pela redução da camada de ozônio) etc.".

O grau e a extensão destes efeitos dependem da escala de poluição, podendo ocorrer em nível local, regional e global. Os efeitos da poluição atmosférica têm a característica de modificar uma condição original ou norma e/ou de intensificar a incidência de um outro efeito, causando um prejuízo ou dano (Pires, 2005).

A poluição atmosférica tem afetado a saúde da população, mesmo quando seus níveis encontram-se aquém do que determina a legislação vigente. As faixas etárias mais atingidas são as crianças e os idosos, grupos bastante suscetíveis aos efeitos deletérios da poluição. Alguns estudos mostraram uma associação positiva entre a mortalidade e também entre a morbidade devido a problemas respiratórios em crianças (Bakonyi, DanniOliveira, Martins, Braga, 2004). 
De acordo com o Ministério do Meio Ambiente (MMA), os principais poluentes são: Aldeídos ( $\mathrm{RCHO})$; Dióxido de Enxofre $\left(\mathrm{SO}_{2}\right)$; Dióxido de Nitrogênio $\left(\mathrm{NO}_{2}\right)$; Hidrocarbonetos ( $\left.\mathrm{HC}\right)$; Material Particulado (MP); Ozônio $\left(\mathrm{O}_{3}\right)$ e Poluentes Climáticos de Vida Curta (PCVC).

A Tabela 1 apresenta uma relação dos principias poluentes atmosféricos, considerados pelo MMA, com a descrição doas fontes e seus efeitos.

Tabela 1 - Principais poluentes atmosféricos, suas fontes e seus principais efeitos na saúde e no meio ambiente

$\begin{array}{lll}\text { Poluente Fontes } \quad \text { Efeitos } & \end{array}$

\begin{tabular}{|c|c|c|}
\hline $\begin{array}{l}\text { Aldeídos } \\
(\mathrm{RCHO})\end{array}$ & $\begin{array}{l}\text { Queima de combustível em } \\
\text { veículos automotores, } \\
\text { principalmente nos veículos que } \\
\text { utilizam etanol. Os aldeídos } \\
\text { emitidos pelos carros são o } \\
\text { Formaldeído e o Acetaldeído } \\
\text { (predominante). }\end{array}$ & $\begin{array}{l}\text { Seus principais efeitos são a } \\
\text { irritação das mucosas, dos olhos, } \\
\text { do nariz e das vias respiratórias } \\
\text { em geral e podem causar crises } \\
\text { asmáticas, são ainda compostos } \\
\text { carcinogênicos potenciais. }\end{array}$ \\
\hline $\begin{array}{l}\text { Dióxido de Enxofre } \\
\qquad\left(\mathrm{SO}_{2}\right)\end{array}$ & $\begin{array}{l}\text { Naturais, como vulcões, } \\
\text { contribuem para o aumento das } \\
\text { concentrações de } \mathrm{SO}_{2} \text { no } \\
\text { ambiente, porém na maior parte } \\
\text { das áreas urbanas as atividades } \\
\text { humanas são as principais fontes } \\
\text { emissoras. A emissão } \\
\text { antropogênica é causada pela } \\
\text { queima de combustíveis fósseis } \\
\text { que contenham enxofre em sua } \\
\text { composição. As atividades de } \\
\text { geração de energia, uso veicular } \\
\text { e aquecimento doméstico são as } \\
\text { que apresentam emissões mais } \\
\text { significativas. }\end{array}$ & $\begin{array}{l}\text { Agravamento dos sintomas da } \\
\text { asma e aumento de internações } \\
\text { hospitalares, decorrentes de } \\
\text { problemas respiratórios. São } \\
\text { precursores da formação de } \\
\text { material particulado secundário. } \\
\text { No ambiente, podem reagir com a } \\
\text { água na atmosfera formando } \\
\text { chuva ácida. }\end{array}$ \\
\hline $\begin{array}{c}\text { Dióxido de } \\
\text { Nitrogênio }\left(\mathrm{NO}_{2}\right)\end{array}$ & $\begin{array}{l}\text { Podem ser naturais (vulcanismos, } \\
\text { ações bacterianas, descargas } \\
\text { elétricas) e antropogênicas } \\
\text { (processos de combustão em } \\
\text { fontes móveis e fixas). As emissões } \\
\text { naturais são em maior escala que } \\
\text { as antropogênicas, porém, em } \\
\text { razão de sua distribuição sobre o } \\
\text { globo terrestre, tem menor impacto } \\
\text { sobre as concentrações deste } \\
\text { poluente nos centros urbanos. }\end{array}$ & $\begin{array}{l}\text { Altas concentrações podem levar } \\
\text { ao aumento de internações } \\
\text { hospitalares, decorrente de } \\
\text { problemas respiratórios, } \\
\text { problemas pulmonares e } \\
\text { agravamento à resposta das } \\
\text { pessoas sensíveis a alérgenos. } \\
\text { No ambiente pode levar a } \\
\text { formação de smog fotoquímico e } \\
\text { a chuvas ácidas. }\end{array}$ \\
\hline Hidrocarbonetos & $\begin{array}{l}\text { Provêm de uma grande variedade } \\
\text { de processos industriais e } \\
\text { naturais. Nos centros urbanos as } \\
\text { principais fontes emissoras são os } \\
\text { carros, ônibus e caminhões, nos }\end{array}$ & $\begin{array}{l}\text { São precursores para a formação } \\
\text { do ozônio troposférico e } \\
\text { apresentam potencial causador } \\
\text { de efeito estufa (metano). }\end{array}$ \\
\hline
\end{tabular}




\begin{tabular}{|c|c|c|}
\hline & $\begin{array}{l}\text { processos de queima } \\
\text { evaporação de combustíveis. }\end{array}$ & \\
\hline $\begin{array}{c}\text { Material } \\
\text { Particulado }\end{array}$ & $\begin{array}{l}\text { Queima de combustíveis fósseis, } \\
\text { queima de biomassa vegetal, } \\
\text { emissões de amônia na } \\
\text { agricultura de e emissões } \\
\text { decorrentes de obras e } \\
\text { pavimentação de vias. }\end{array}$ & $\begin{array}{l}\text { Estudos indicam que os efeitos } \\
\text { do material particulado sobre a } \\
\text { saúde incluem: câncer } \\
\text { respiratório, arteriosclerose, } \\
\text { inflamação de pulmão, } \\
\text { agravamento de sintomas de } \\
\text { asma, aumento de internações } \\
\text { hospitalares e podem levar à } \\
\text { morte. }\end{array}$ \\
\hline $\begin{array}{l}\text { Monóxido de } \\
\text { Carbono }\end{array}$ & $\begin{array}{l}\text { Processos de combustão que } \\
\text { ocorrem em condições não ideais, } \\
\text { em que não há oxigênio suficiente } \\
\text { para realizar a queima completa } \\
\text { do combustível. A maior parte das } \\
\text { emissões em áreas urbanas são } \\
\text { decorrentes dos veículos } \\
\text { automotores. }\end{array}$ & $\begin{array}{l}\text { Este gás tem alta afinidade com a } \\
\text { hemoglobina no sangue, } \\
\text { substituindo o oxigênio e } \\
\text { reduzindo a alimentação deste ao } \\
\text { cérebro, coração e para o resto } \\
\text { do corpo, durante o processo de } \\
\text { respiração. Em baixa } \\
\text { concentração causa fadiga e dor } \\
\text { no peito, em alta concentração } \\
\text { pode levar a asfixia e morte. }\end{array}$ \\
\hline $\begin{array}{c}\text { Ozônio } \\
\text { Troposférico }\end{array}$ & $\begin{array}{l}\text { Ocorre através de reações } \\
\text { químicas complexas que } \\
\text { acontecem entre o dióxido de } \\
\text { nitrogênio e compostos orgânicos } \\
\text { voláteis, na presença de radiação } \\
\text { solar. Estes poluentes são } \\
\text { emitidos principalmente na } \\
\text { queima de combustíveis fósseis, } \\
\text { volatilização de combustíveis, } \\
\text { criação de animais e na } \\
\text { agricultura. }\end{array}$ & $\begin{array}{l}\text { Agravamento dos sintomas de } \\
\text { asma, de deficiência respiratória, } \\
\text { bem como de outras doenças } \\
\text { pulmonares } \\
\text { bronquites, (enfisemas, } \\
\text { cardiovasculares etc.) } \\
\text { (arteriosclerose). Longo tempo de } \\
\text { exposição pode ocasionar } \\
\text { redução na capacidade pulmonar, } \\
\text { desenvolvimento de asma e } \\
\text { redução na expectativa de vida. }\end{array}$ \\
\hline $\begin{array}{c}\text { Poluentes } \\
\text { Climáticos de Vida } \\
\text { Curta }\end{array}$ & $\begin{array}{l}\text { As fontes principais de carbono } \\
\text { negro são a queima ao ar livre de } \\
\text { biomassa, motores a diesel e a } \\
\text { queima residencial de de } \\
\text { combustíveis sólidos (carvão, } \\
\text { madeira). As fontes de metano } \\
\text { antropogênicas são sistemas de } \\
\text { óleo e gás, agricultura, criação de } \\
\text { animais, aterros sanitários e } \\
\text { tratamentos de esgotos. Com } \\
\text { relação aos HFCs seu uso ocorre } \\
\text { principalmente em sistemas de ar } \\
\text { condicionado, refrigeração, } \\
\text { supressores de queima, solventes } \\
\text { e aerossóis. }\end{array}$ & $\begin{array}{l}\text { Efeitos negativos sobre a saúde } \\
\text { humana, sobre os ecossistemas } \\
\text { e sobre a produção agrícola. O } \\
\text { carbono negro é um dos } \\
\text { componentes do material } \\
\text { particulado, o qual apresenta } \\
\text { efeitos nocivos sobre os sistemas } \\
\text { respiratório e sanguíneo, } \\
\text { podendo levar a óbito. O metano } \\
\text { tem grande potencial de } \\
\text { aquecimento global, além de ser } \\
\text { precursor na formação do ozônio } \\
\text { troposférico. Os HFCs, assim } \\
\text { como o metano, também } \\
\text { apresentam grande potencial de } \\
\text { aquecimento global. }\end{array}$ \\
\hline
\end{tabular}

Fonte: Adaptada do Ministério do Meio Ambiente. 


\subsection{Inventário de Emissões Atmosféricas}

Os inventários de emissões atmosféricas apresentam inúmeras finalidades, incluindo a modelagem de dispersão das emissões, análise do ambiente, desenvolvimento de estratégia de controle e seleção de fontes para investigações de conformidades (EPA, 1995).

São instrumentos que possibilitam analisar a quantidade, natureza e localização das emissões que ocorrem numa determinada área durante um período de tempo, identificando os setores de atividades e os locais responsáveis pelas maiores emissões de poluentes para a atmosfera. Sendo fundamentais na avaliação e gestão da qualidade do ar, a nível nacional ou a nível regional (CCDR-LVT, 2006).

Além das estimativas de emissões, os inventários geralmente contêm também dados de apoio, por exemplo: os locais das fontes de emissão; medições das emissões, quando disponível; fatores de emissão, as taxas de capacidade de produção ou de atividade nos vários setores de origem; as condições de operação, métodos de medição ou estimativa, etc. (EEA, 2013).

Para atualizar as informações relativas às fontes fixas, em 2009 e 2010, a CETESB desenvolveu o Sistema de Inventario de Emissões de Fontes Estacionárias no Estado de São Paulo - SIEFEESP. Ferramenta que oferece uma ampla visão dessas emissões, auxiliando na implantação de programas de mitigação que promovam iniciativas de redução mais eficazes das emissões no Estado de São Paulo (CETESB, 2011).

Inventários de emissões constituem a base para a modelagem regional e análise da qualidade do ar, a fim de compreender melhor o mecanismo de formação e o transporte de poluentes. Sendo fundamental para o estudo da química atmosférica e desenvolvimento de políticas de controle de uma região (Li et al., 2011, Qiu et al., 2014).

A primeira etapa no planejamento de um inventário é definir seu escopo e estabelecer previamente os poluentes que serão considerados. Nem sempre a decisão é baseada no conhecimento da causa em questão, pela 
carência de informações essenciais da qualidade das emissões geradas, o que pode ser resolvido com uma inspeção dos processos que emitem os poluentes atmosféricos ou em recorrência à literatura.

O conhecimento de quais poluentes são frequentemente monitorados ou utilizados como padrões regulamentados fornece também diretrizes neste sentido (Pires, 2005).

A EPA usualmente utiliza poluentes indicadores da qualidade do ar, padrões nacionais da qualidade do ar, como os principais poluentes componentes dos inventários. Estes poluentes são o ozônio $\left(\mathrm{O}_{3}\right)$, monóxido de carbono (CO), os óxidos de nitrogênio $\left(\mathrm{NO}_{\mathrm{X}}\right)$, o dióxido de enxofre $\left(\mathrm{SO}_{2}\right)$, o material particulado com diâmetro aerodinâmico menor ou igual a 2,5 micras $\left(\mathrm{PM}_{2,5}\right)$. Além destes poluentes, a EPA regula as emissões de compostos orgânicos voláteis (VOC's) em seu programa de estabelecimento de padrões. Estes poluentes são os percussores do ozônio sendo emitido dos motores de veículos na fase de distribuição de combustíveis, em fábricas químicas e de uma grande variedade de processos industriais onde se utiliza solvente como matéria-prima (EPA, 1999).

Os poluentes relevantes, fontes emissoras, categorias de fonte e fronteiras geográficas precisam ser identificados antes do início da coleta de dados. Um plano de preparação de inventário deve especificar os procedimentos a serem usados para coletar, processar, analisar e relatar os dados de emissões (EPA, 1997; EPA, 2001).

O processo de elaboração do inventário deve abordar quais os métodos utilizados na estimativa das emissões. Os três principais métodos utilizados são: Testes de fonte; Balanço de materiais e Fatores de emissão (EPA, 2001). 


\subsection{Métodos de Estimativa de Emissão/Potencial Poluidor}

\subsubsection{Fatores de Emissão}

A precisão da estimativa de emissão é um dos requisitos básicos para elaboração de qualquer inventário, devendo incluir detalhes de todas as fontes relevantes (Fairmode, 2010).

No processo de medição dos parâmetros, quando na ausência de dados de amostragem, as emissões podem ser estimadas por meio do emprego de fatores de emissão, sendo os mais adequados ao método de estimativa (CETESB, 2009; CETESB 2011).

A EPA define o fator de emissão como um valor que relaciona a quantidade liberada de poluentes associada a parâmetros ligados à atividade industrial (quantidade produzida, quantidade de matéria-prima consumida, dentre outros), de forma que tais fatores possam ser usados em equações para estimar emissões de um processo industrial em que não há disponibilidade de dados específicos (EPA, 2013b).

Devido a sua disponibilidade e aceitação na Indústria, os fatores de emissão são usualmente utilizados na preparação do inventário de emissões. A determinação dos fatores de emissão é baseada em testes de emissão realizados em unidades fabris funcionalmente similares. Contudo, o seu utilizador deve reconhecer que, na maior parte dos casos, os fatores de emissão são resultantes de médias numa imensidão de dados industriais com diferentes graus de qualidade. Consequentemente, os fatores de emissão não podem ser representativos de uma unidade fabril individual do mesmo setor industrial (Lima, 2009).

A EPA possui um acervo de fatores de emissão para os diferentes tipos de indústrias, processos, equipamentos e combustíveis responsáveis por emissões de diversos poluentes.

Os fatores de emissões são geralmente apresentados em massa de poluente dividido pela unidade de massa, volume, distância, ou duração da 
atividade geradora.

A base para calcular as emissões usando os fatores de emissão é expressa pela Equação 1.

$$
\boldsymbol{E} x=\boldsymbol{F} \boldsymbol{E} x \boldsymbol{A}
$$

Onde:

Ex Emissão horária do poluente $\mathbf{X}$

FEx Fator de emissão de $\mathbf{X}$

A Taxa de Atividade

Os fatores de emissão são aplicados na hipótese de que todas as unidades industriais do mesmo produto têm modelos de emissão similares. 0 principal critério que afeta a seleção do fator de emissão é o grau de similaridade entre o equipamento ou processo selecionado para aplicação do fator e o equipamento ou processo utilizado em seu cálculo (CETESB, 2010).

A seleção dos fatores de emissão apropriados é de fundamental importância na determinação das emissões totais. Podendo ocorrer divergência grande entre a realidade da liberação e o que é estimado pelos fatores (MMA, 2013).

\subsubsection{Modelos de Emissões Atmosféricas}

Modelos de emissões podem ser utilizados para estimar as emissões nos casos em que a abordagem matemática é complexa, ou nos casos em que uma combinação de parâmetros identificados afeta as emissões, mas, individualmente, não fornecem uma correlação direta (EPA, 2001).

O uso de modelos de emissão e equações geralmente envolve mais esforço do que o uso de fatores de emissão. O nível de esforço está relacionado com a complexidade da equação, os tipos de dados que devem ser coletados, e a diversidade de produtos fabricados em uma instalação (EPA, 1997b).

Vários modelos de emissões podem ser aplicados a muitas operações 
unitárias como enchimento, mistura, aquecimento, despressurizarão, moagem, e outros (EPA, 2007).

\subsubsection{Balanço de Massa}

Neste método as emissões são estimadas pela diferença entre a quantidade de material que entra e a quantidade de material que sai de um processo ou toda a atividade industrial (Pires, 2005).

Esta metodologia utiliza o consumo de matéria-prima, bem como a fração de cada poluente na mesma e a quantidade de material reciclado, eliminado e/ou reconvertido para estimar a quantidade de poluente emitida. É normalmente utilizada na estimativa de emissão de partículas, COVs e metais pesados. O "balanço material" é frequentemente usado quando uma quantidade constante de material é emitida durante o seu uso e/ou todas as emissões não estão sujeitas a mecanismos de controle. Contudo, esta metodologia também é aplicável na existência de mecanismos de controle, se o fator de eficiência relativo a cada tipo de equipamento for conhecido (Lima, 2009).

Como a estimativa está baseada na quantidade de material que entra no processo e no que sai deste, um mínimo erro em qualquer destes valores poderá resultar em grandes erros percentuais nas estimativas das emissões (EPA, 1999; EPA 1997b).

A emissão de um poluente pode ser determinada pela Equação 2. 


$$
E_{x}=\left[\left(Q_{m p e}-Q_{m r}-Q_{m c}-Q_{m p s}\right) x C_{m x}\right] x\left(1-\eta_{\text {controle }}\right)
$$

Onde:

$E_{\mathbf{x}}$ Emissão horária do poluente $\mathrm{X}$

$Q_{\text {mpe }}$ Caudal mássico de matéria-prima à entrada

$\mathbf{Q}_{\mathrm{mr}}$ Caudal mássico de matéria-prima reciclada

$\mathbf{Q}_{\mathrm{mc}}$ Caudal mássico de matéria-prima reconvertida

$\mathbf{Q}_{\mathrm{mps}}$ Caudal mássico de matéria-prima à saída

$\mathbf{C}_{\mathrm{mx}}$ Teor mássico médio do poluente $\mathrm{X}$ na matéria-prima

$\eta_{\text {controle }}$ Eficiência de remoção do equipamento de controle

\subsection{Gestão da Qualidade do Ar no Brasil}

As experiências do homem com os efeitos da poluição atmosférica não são recentes. Entretanto, no último século o conhecimento de técnicas mais precisas de avaliação dessa poluição e seus efeitos, além, da ocorrência de episódios de deterioração da qualidade do ar e registros de consequências provenientes desses episódios, motivaram o discurso pró-saúde e bem-estar da sociedade (Souza, 2009).

A preocupação inicial dos governos eram as fontes móveis, no entanto percebeu-se ser de igual importância a criação de um programa nacional que contemplasse as fontes fixas de poluição atmosférica. Foi observado que os estados não dispunham de padrões locais de emissão de fontes e ficou claro que havia necessidade da fixação de dispositivos de caráter normativo e do estabelecimento de ações de monitoramento atmosférico. Ao longo dos anos, diversas legislações foram criadas, com a finalidade de promover uma melhor gestão da qualidade do ar.

Na década de 1980, a lei federal brasileira ํㅜ 6.938/81 definiu os objetivos e instrumentos da Política Nacional de Meio Ambiente (PNMA) e criou o Sistema Nacional de Meio Ambiente (SISNAMA). Neste sistema, destaca-se a criação do Conselho Nacional do Meio Ambiente (CONAMA), formado por representantes da administração pública e da sociedade civil, com as funções de assessorar, estudar e propor diretrizes de políticas governamentais para 0 meio ambiente. Ressalta-se que os instrumentos da Política Nacional do Meio 
Ambiente - PNMA resultaram na criação do Sistema de Licenciamento de atividades poluidoras e degradadoras do meio ambiente. Esse licenciamento é realizado, desde então, pelas instituições ambientais federais, estaduais e municipais. Neste sentido, o licenciamento ambiental tem por finalidade promover o controle ambiental prévio desses empreendimentos e atividades (inciso IV, art. 9º, da lei 6.938/81).

O licenciamento ambiental é uma obrigação legal prévia à instalação de qualquer empreendimento ou atividade potencialmente poluidora ou degradadora do meio ambiente e possui como uma de suas mais expressivas características a participação social na tomada de decisão, por meio da realização de Audiências Públicas como parte do processo. Essa obrigação é compartilhada pelos Órgãos Estaduais de Meio Ambiente e pelo Instituto Brasileiro do Meio Ambiente e Recursos Naturais Renováveis - IBAMA, como partes integrantes do SISNAMA.

A Tabela 2 apresenta um resumo dos principais instrumentos reguladores quanto à poluição atmosférica em âmbito federal e estadual.

Tabela 2 - Instrumentos Legais para Controle da Poluição Atmosférica em nível Federal e Estadual

Nível Documento Medida

\begin{tabular}{|c|c|c|}
\hline Federal & $\begin{array}{c}\text { Portaria Minter, } 231 \text { de } 27 \text { de } \\
\text { abril de } 1976 .\end{array}$ & $\begin{array}{l}\text { Estabelece padrões de qualidade do } \\
\text { ar }\end{array}$ \\
\hline Federal & $\begin{array}{l}\text { Lei } 6938 \text {, de } 31 \text { de agosto de } \\
1981 .\end{array}$ & $\begin{array}{l}\text { Estabelece a Política Nacional } \\
\text { Meio Ambiente, seus fins } \\
\text { mecanismos de formulação e } \\
\text { aplicação. }\end{array}$ \\
\hline Federal & $\begin{array}{l}\text { Resolução CONAMA n0ㅜ, de } \\
\text { 23de janeiro de } 1986 .\end{array}$ & $\begin{array}{l}\text { Define critérios para o licenciamento } \\
\text { ambiental, } \\
\text { obrigatoriedade de estabelecendo aboração de } \\
\text { EIA/RIMA. }\end{array}$ \\
\hline Federal & $\begin{array}{l}\text { Constituição Federal, 1988, } \\
\text { capítulo IV, Artigo } 225 .\end{array}$ & $\begin{array}{l}\text { Estabelece a competência da União, } \\
\text { Estado e Municípios de "proteger o } \\
\text { meio ambiente e combater a poluição } \\
\text { em qualquer de suas formas". }\end{array}$ \\
\hline Federal & $\begin{array}{l}\text { Decreto } 1.413 \text {, de } 14 \text { de } \\
\quad \text { agosto de } 1975 .\end{array}$ & $\begin{array}{l}\text { Dispõe sobre o controle da poluição } \\
\text { do meio ambiente provocada por } \\
\text { atividades industriais. }\end{array}$ \\
\hline
\end{tabular}




\begin{tabular}{|c|c|c|}
\hline Federal & $\begin{array}{l}\text { Resolução CONAMA no 5, de } \\
15 \text { de junho de } 1989 .\end{array}$ & $\begin{array}{l}\text { Estabelece o PRONAR, Programa } \\
\text { Nacional de Qualidade do Ar. }\end{array}$ \\
\hline Federal & $\begin{array}{l}\text { Resolução CONAMA no3, de } \\
28 \text { de junho de } 1990 \text {. }\end{array}$ & $\begin{array}{l}\text { Estabelece padrões de qualidade do } \\
\text { ar. }\end{array}$ \\
\hline Federal & $\begin{array}{l}\text { Resolução CONAMA nº, de } \\
06 \text { de dezembro de } 1990 .\end{array}$ & $\begin{array}{l}\text { Estabelece limites máximos de } \\
\text { poluentes do ar para processos de } \\
\text { combustão externa. }\end{array}$ \\
\hline Federal & $\begin{array}{l}\text { Resolução CONAMA no-237, de } \\
19 \text { de dezembro } 1997\end{array}$ & $\begin{array}{l}\text { Define critérios para licenciamento } \\
\text { ambiental }\end{array}$ \\
\hline Federal & $\begin{array}{l}\text { Resolução CONAMA no } 382 \text {, } \\
\text { de } 26 \text { de dezembro de } 2006 \text {. }\end{array}$ & $\begin{array}{l}\text { Estabelece os limites máximos de } \\
\text { emissão de poluentes atmosféricos } \\
\text { para fontes fixas }\end{array}$ \\
\hline Estadual & $\begin{array}{l}\text { Lei no 997, de } 31 \text { de maio de } \\
1976 .\end{array}$ & $\begin{array}{l}\text { Dispõe sobre o Controle da Poluição } \\
\text { do Meio Ambiente. }\end{array}$ \\
\hline Estadual & $\begin{array}{c}\text { Lei 9.509, de } 20 \text { de março de } \\
1997 .\end{array}$ & $\begin{array}{l}\text { Sobre Política Estadual do Meio } \\
\text { Ambiente }\end{array}$ \\
\hline Estadual & $\begin{array}{l}\text { Decreto } 8.468 \text {, de } 08 \text { de } \\
\text { setembro de } 1976 .\end{array}$ & $\begin{array}{l}\text { Regula a Lei 997/76, Cap. I Das } \\
\text { Normas para Utilização e Preservação } \\
\text { do ar }\end{array}$ \\
\hline Estadual & $\begin{array}{l}\text { Decreto } \mathrm{n}^{\circ} \text { 50. } 753 \text {, de } 28 \text { de } \\
\text { abril de } 2006 \text {. }\end{array}$ & $\begin{array}{l}\text { Altera a redação e inclui dispositivos } \\
\text { no Regulamento aprovado pelo } \\
\text { Decreto n. } 8.468 \text {, de } 8 \text { de setembro de } \\
\text { 1976, disciplinando a execução da Lei } \\
\text { no 997, de } 31 \text { de maio de } 1976 \text {, que } \\
\text { dispõe sobre controle da poluição do } \\
\text { meio ambiente e dá providências } \\
\text { correlatas }\end{array}$ \\
\hline Estadual & $\begin{array}{l}\text { Decreto no } 52.469, \text { de } 12 \text { de } \\
\text { dezembro de } 2007 \text {. }\end{array}$ & $\begin{array}{l}\text { Altera a redação de dispositivos do } \\
\text { Regulamento aprovado pelo Decreto } \\
\text { no } 8.468 \text {, de } 8 \text { de setembro de 1976, } \\
\text { que dispõe sobre o controle da } \\
\text { poluição do meio ambiente. }\end{array}$ \\
\hline Estadual & $\begin{array}{l}\text { Decisão de Diretoria no } 010 \text { / } \\
2010 \text { / P, de } 12 \text { de janeiro de } \\
2010 .\end{array}$ & $\begin{array}{l}\text { Dispõe sobre o Monitoramento de } \\
\text { Emissões de Fontes Fixas de } \\
\text { Poluição do Ar no Estado de São } \\
\text { Paulo - Termo de Referência para a } \\
\text { Elaboração do Plano de de } \\
\text { Monitoramento Emissões } \\
\text { Atmosféricas (PMEA) }\end{array}$ \\
\hline Estadual & $\begin{array}{c}\text { Decreto } 59.113 \text {, de } 23 \text { de abril } \\
\text { de } 2013 .\end{array}$ & $\begin{array}{l}\text { Estabelece novos padrões de } \\
\text { qualidade do ar e dá providências } \\
\text { correlatas }\end{array}$ \\
\hline
\end{tabular}




\subsection{Gestão da Qualidade do Ar em outros países}

\subsubsection{Estados Unidos}

No que se refere à poluição atmosférica, a EPA tem como referência a lei federal americana intitulada Clean Air Act, de 1963, criada para proteger e melhorar a qualidade do ar no país, tendo em vista a promoção da saúde. Pela lei, a EPA determina dois padrões da qualidade do ar: padrões primários, que proveem proteção à saúde pública, incluindo a população mais vulnerável, como crianças, idosos e pessoas com doenças respiratórias; e padrões secundários, que protegem o meio ambiente (de maneira indireta também o bem-estar público) de qualquer efeito adverso conhecido ou associado à presença de poluentes atmosféricos, incluindo a proteção contra diminuição da visibilidade por poluição, danos à vegetação, culturas de alimentos, animais e edifícios (EPA, 2012).

Os padrões nacionais de qualidade do ar (NAAQS, em inglês, National Ambient Air Quality Standards) são definidos pela EPA para os seis principais poluentes mais comuns e nocivos à saúde, que são: monóxido de carbono, chumbo, dióxido de nitrogênio, ozônio, material particulado e dióxido de enxofre, os quais devem ser revistos e atualizados periodicamente para garantir a proteção adequada à saúde e ao meio ambiente (EPA, 2012). No sentido de controlar a qualidade do ar, a Agência possui dados armazenados das redes de monitoramento da qualidade do ar desde 1980, que são disponibilizados publicamente no site da EPA.

\subsubsection{União Europeia}

A Europa comprometeu-se firmemente a proteger o meio ambiente a partir do início dos anos 70 . Suas normas ambientais foram sendo desenvolvidas ao longo de décadas, em resposta a toda uma variedade de problemas. Hoje em dia, a luta contra a redução dos problemas de saúde causados pela poluição do ar está entre as grandes prioridades e tais iniciativas, na medida em que incentivam a inovação e o empreendedorismo, contribuem para o crescimento econômico (Cavalcanti, 2010). 
Os países da União Europeia, tendo em vista principalmente a proteção de sua população, são obrigados a controlar alguns poluentes e a tomar medidas caso os limites de segurança destes sejam excedidos.

Como parte do quadro de políticas climáticas e energéticas, em 2030, a UE comprometeu-se a reduzir as emissões no território da UE em pelo menos 40\% relativamente aos níveis de 1990 (EEA, 2008).

Uma diretriz institui os princípios básicos de uma estratégia comum a fim de evitar, minimizar ou reduzir e os efeitos nocivos à saúde humana e ao meio ambiente.

A Diretiva 96/62/CE, de 27 de setembro de 1996, define princípios básicos e estratégia para a gestão da qualidade do ar, já tendo sido alterada pelo Regulamento CE n. 188/2003 e Diretiva 2008/50/CE, que passou a vigir em junho de 2010, ela complementa a legislação europeia no domínio da melhoria da qualidade do ar que envolve: a Diretiva 80/779/CEE, sobre padrões de qualidade do ar e valores de referência para o dióxido de enxofre e partículas em suspensão; a Diretiva 82/884/CEE, relativa ao limite para o chumbo contido na atmosfera; a Diretiva 85/203/CEE, relativa às normas de qualidade do ar para o dióxido de enxofre; e a Diretiva 92/72/CEE, relativa à poluição do ar pelo ozônio (Cavalcanti, 2010).

\subsection{Critérios e Procedimentos para a revisão dos Padrões de Qualidade do $\mathrm{Ar}$}

A finalidade do controle da poluição do ar é prevenir os efeitos adversos nos humanos, nos animais, nos vegetais e nos materiais. O tempo desses efeitos pode apresentar um período de resposta de curto, intermediário e longo. A fim de evitar efeitos prejudiciais, a concentração de poluentes atmosféricos deve estar abaixo do nível de concentração a que esses efeitos ocorrem.

Os critérios de qualidade do ar são relações de causa-efeito, obtidos experimentalmente das observações da exposição a vários níveis de um poluente específico, utilizados para a definição dos padrões de qualidade do ar (Stern et al, 1984). 
Estes critérios estipulam as condições de exposição e devem ser determinados em observações de grupos ou populações sensíveis a um único poluente ou ao efeito conjunto de vários poluentes. Eles descrevem os efeitos que devem ser esperados se o nível de determinado poluente no ar alcança ou excede uma concentração específica num período de tempo. O estabelecimento destes critérios é um processo dinâmico e, portanto, passível de ocorrer mudanças na medida em que novas informações tornam-se disponíveis (Pires, 2005).

A Organização Mundial da Saúde (OMS) estimou recentemente que uma em cada nove mortes em 2012 está relacionada com doenças causadas por agentes cancerígenos e outros venenos presentes no ar. A poluição do ar é apontada, juntamente com 0 desmatamento, extinção de espécies, a degradação do solo e superpopulação representam hoje as 05 grandes ameaças ambientais do mundo, que devem ser resolvidas para que o planeta continue sendo um lar para todas as espécies (Santos, et al., 2016).

Os padrões de qualidade do ar devem ser definidos a partir do levantamento e da avaliação de dados, como por exemplo: a severidade e a frequência dos efeitos adversos de cada poluente sobre a saúde e o meio ambiente, a localização e concentração do contaminante no ambiente, sua persistência, etc.

A OMS aborda a relação entre a poluição atmosférica e os problemas de saúde e publica recomendações quanto às concentrações ambientais de alguns poluentes a fim de auxiliar gestores ambientais de cada país, proporcionando a definição e alcance de objetivos de gestão da qualidade do ar para uma maior proteção à saúde. Em geral, tais recomendações são formalizadas por meio dos guidelines, servindo como orientação geral para os países desenvolverem e revisarem padrões nacionais (Who, 2005).

\subsection{Padrões de Qualidade do Ar no Brasil}

No Brasil, a Resolução CONAMA 05/89 considera a necessidade de adoção de padrões nacionais de qualidade do ar como ação complementar e referencial aos limites máximos de emissão estabelecidos (CONAMA, 1990) Considera, portanto, os padrões de qualidade do ar como instrumentos de apoio e operacionalização do PRONAR. A resolução CONAMA 03/90 regulamentou os 
valores em concentração de poluentes, dos padrões nacionais de qualidade do ar para Partículas totais em Suspensão (PTS), Fumaça (FMC), Partículas Inaláveis $\left(\mathrm{MP}_{10}\right)$, Dióxido de Nitrogênio $\left(\mathrm{NO}_{2}\right)$, Dióxido de Enxofre $\left(\mathrm{SO}_{2}\right)$, Monóxido de Carbono (CO) e Ozônio $\left(\mathrm{O}_{3}\right)$, a resolução CONAMA 436/2011 estabelece os limites máximos de emissão de poluentes atmosféricos para fontes fixas instaladas ou com pedido de licença de instalação anterior a 02 de janeiro de 2007.

Os padrões brasileiros seguem a mesma classificação dos padrões americanos, podendo ser de dois tipos: primários e secundários (Oliveira, 1997):

- Padrões Primários de Qualidade do Ar são as concentrações de poluentes que, ultrapassadas, poderão afetar a saúde da população (CONAMA, 1990a);

- Padrões Secundários de Qualidade do Ar são as concentrações de poluentes abaixo dos quais se prevê o mínimo efeito adverso sobre o bem estar da população, assim como o mínimo dano à fauna, à flora, aos materiais e ao meio ambiente em geral (CONAMA, 1990a).

Os padrões de qualidade do ar de São Paulo foram estabelecidos em 1976, pelo Decreto Estadual ํo 8468/76. Baseando-se nas diretrizes da OMS, o estado deu início a um processo de revisão dos padrões de qualidade do ar, culminando mais tarde, na publicação do Decreto Estadual no 59113 de 23/04/2013, que estabelece novos padrões de qualidade do ar. A NBR no $11175 / 1990$ fixa as condições exigíveis de desempenho do equipamento para incineração de resíduos sólidos perigosos.

A Tabela 3 apresenta o resumo dos padrões estaduais de qualidade do ar estabelecidos no DE no $59113 / 2013$, sendo que os padrões vigentes estão assinalados em vermelho. 
Tabela 3 - Padrões estaduais de qualidade do ar

\begin{tabular}{|c|c|c|c|c|c|}
\hline Poluente & $\begin{array}{c}\text { Tempo de } \\
\text { Amostragem }\end{array}$ & $\begin{array}{c}\text { Ml1 } \\
\left(\mu \mathrm{g} / \mathrm{m}^{3}\right)\end{array}$ & $\begin{array}{c}\mathrm{Ml2} \\
\left(\mu \mathrm{g} / \mathrm{m}^{3}\right)\end{array}$ & $\begin{array}{c}\text { MI 3 } \\
\left(\mu \mathrm{g} / \mathrm{m}^{3}\right)\end{array}$ & $\begin{array}{c}\text { PF } \\
\left(\mu \mathrm{g} / \mathrm{m}^{3}\right)\end{array}$ \\
\hline \multirow[b]{2}{*}{$\mathrm{MP}_{10}$} & $24 h$ & 120 & 100 & 75 & 50 \\
\hline & $\mathrm{MMA}^{1}$ & 40 & 35 & 30 & 20 \\
\hline \multirow[b]{2}{*}{$\mathrm{MP}_{2,5}$} & $24 h$ & 60 & 50 & 37 & 25 \\
\hline & $\mathrm{MMA}^{1}$ & 20 & 17 & 15 & 10 \\
\hline \multirow[b]{2}{*}{$\mathrm{SO}_{2}$} & $24 h$ & 60 & 40 & 30 & 20 \\
\hline & $\mathrm{MMA}^{1}$ & 40 & 30 & 20 & - \\
\hline \multirow[b]{2}{*}{$\mathrm{NO}_{2}$} & $1 \mathrm{~h}$ & 260 & 240 & 220 & 200 \\
\hline & $\mathrm{MMA}^{1}$ & 60 & 50 & 45 & 40 \\
\hline $\mathrm{O}_{3}$ & $8 \mathrm{~h}$ & 140 & 130 & 120 & 100 \\
\hline $\mathrm{CO}$ & $8 \mathrm{~h}$ & - & - & - & $9 \mathrm{ppm}$ \\
\hline \multirow[b]{2}{*}{$\mathrm{FMC}^{*}$} & $24 h$ & 120 & 100 & 75 & 50 \\
\hline & $\mathrm{MMA}^{1}$ & 40 & 35 & 30 & 20 \\
\hline \multirow[b]{2}{*}{ PTS* } & $24 h$ & - & - & - & 240 \\
\hline & $\mathrm{MMA}^{1}$ & - & - & - & 80 \\
\hline $\mathrm{Pb}^{\star *}$ & $\mathrm{MMA}^{1}$ & - & - & - & 0,5 \\
\hline \multicolumn{6}{|c|}{$\begin{array}{l}\text { Fonte: Adaptada CETESB, } 2015 . \\
1 \text { - Média aritmética anual. } \\
2 \text { - Média geométrica anual. } \\
\text { * Fumaça e Partículas Totais em Suspensão - parâmetros auxiliares a serem utilizados apenas } \\
\text { em situações específicas, a critério da CETESB. } \\
\text { ** Chumbo - a ser monitorado apenas em áreas específicas, a critério da CETESB. }\end{array}$} \\
\hline
\end{tabular}

A Figura 1 apresenta, de forma resumida, uma comparação dos diferentes poluentes, os valores estabelecidos pela OMS e os recomendados pelo CONSEMA (Conselho Superior de Meio Ambiente), bem como os padrões nacionais de qualidade do ar, em vigor, estabelecidos pela Resolução CONAMA. Vale ressaltar que a adoção desses novos padrões de qualidade do ar impacta significativamente nas atuais emissões das fontes de emissão, levando à necessidade de reavaliar as emissões potencialmente poluidoras da atmosfera por meio de monitoramento tecnicamente adequado (Nefussi, 2013). 
Figura 1 - Resumo dos padrões de emissão e legislações vigentes

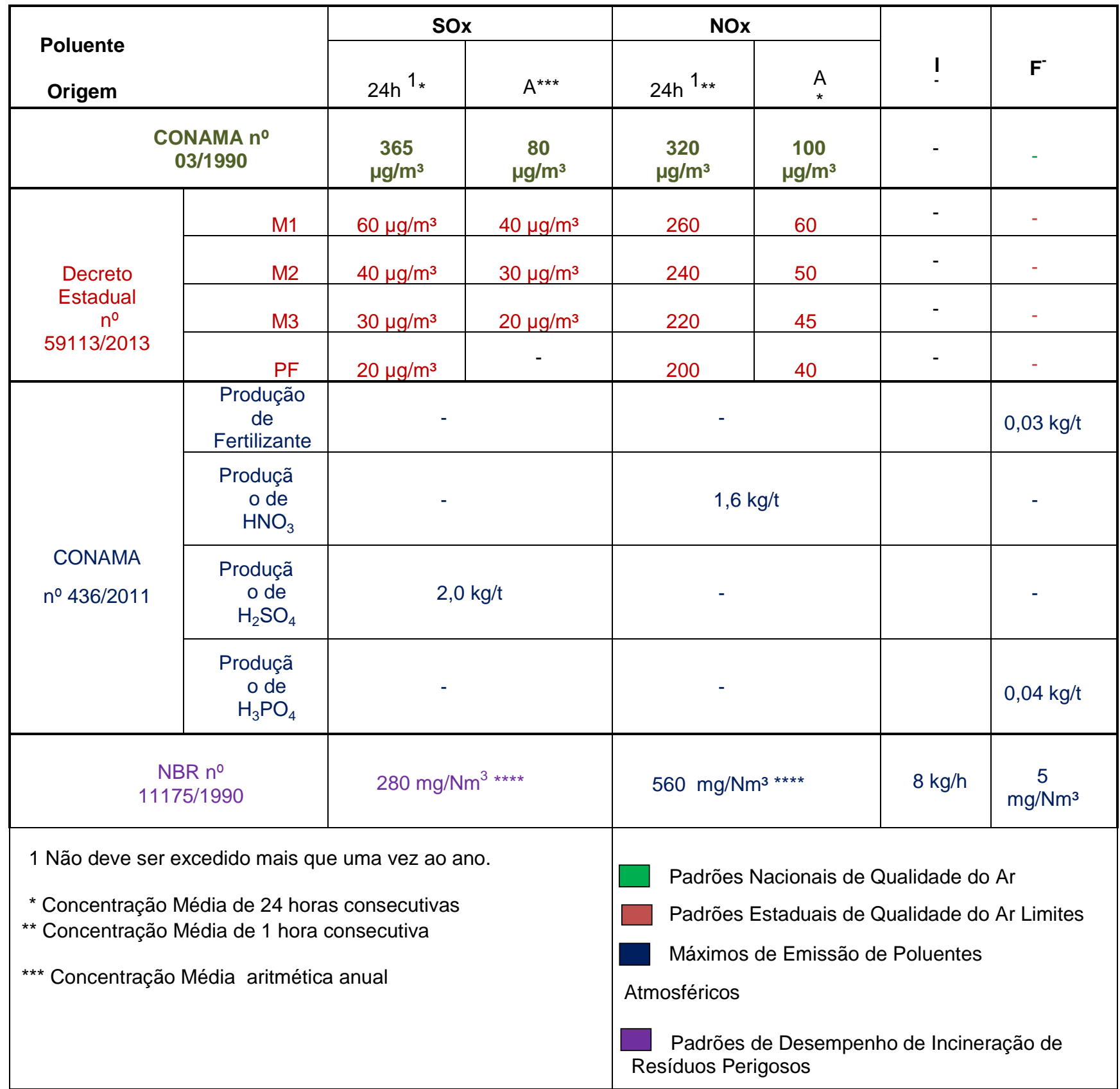

MI1 Meta Intermediária Etapa 1; MI2 Meta Intermediária Etapa 1; MI3 Meta Intermediária Etapa 1; PF Padrões Finais

\subsection{Padrões de Qualidade do Ar nos Estados Unidos}

Os padrões de qualidade do ar devem refletir os conhecimentos científicos mais recentes, ser revistos pela EPA a cada cinco anos (nem sempre acontece), em um processo que contempla etapas de planejamento, avaliações científicas quanto ao de risco à exposição, avaliação de políticas, e, por fim, regulamentação (MMA, 2013). 
Atualmente, a legislação dos EUA estabelece padrões de qualidade do ar para $\mathrm{CO}$, Chumbo, $\mathrm{NO}_{2}, \mathrm{O}_{3}, \mathrm{MP}_{2,5}, \mathrm{MP}_{10}$ e $\mathrm{SO}_{2}$, cujos valores estão sumarizados na Tabela 4.

Tabela 4 - Padrões nacionais de qualidade do ar adotados no EUA

\begin{tabular}{ccc}
$\begin{array}{c}\text { Poluente (último ano } \\
\text { de revisão) }\end{array}$ & $\begin{array}{c}\text { Tempo de } \\
\text { Amostragem }\end{array}$ & Concentração \\
\hline $\mathrm{CO}$ & $8 \mathrm{~h}$ & $9 \mathrm{ppm}$ \\
$(2011)$ & $1 \mathrm{~h}$ & $35 \mathrm{ppm}$ \\
\hline $\begin{array}{c}\text { Chumbo } \\
(2008)\end{array}$ & $\begin{array}{c}\text { Média Móvel } \\
\text { Trimestral }\end{array}$ & $0,15 \mu \mathrm{g} / \mathrm{m}^{3}$ \\
\hline $\mathrm{NO}_{2}$ & $1 \mathrm{~h}$ & $100 \mathrm{ppb}$ \\
$(2010)$ & Anual & $53 \mathrm{ppb}$ \\
\hline $\mathrm{O}_{3}$ & $8 \mathrm{~h}$ & $0,075 \mathrm{ppm}$ \\
$(2008)$ & Anual & $15 \mu \mathrm{g} / \mathrm{m}^{3}$ \\
\hline $\mathrm{MP}_{2,5}$ & $24 \mathrm{~h}$ & 35 \\
$(2006)$ & $24 \mathrm{~h}$ & $150 \mu \mathrm{g} / \mathrm{m}^{3}$ \\
\hline $\mathrm{MP}_{10}$ & $1 \mathrm{~h}$ & $75 \mathrm{ppb}$ \\
$(2006)$ & $3 \mathrm{~h}$ & $0,5 \mathrm{ppm}$
\end{tabular}

Fonte: Adaptado EPA (2011b).

\subsection{Padrões de Qualidade do Ar na União Europeia}

$\mathrm{Na}$ União Europeia os valores são divididos entre "valores-limite" e "valores-alvo". Ambos são definidos como a concentração limite para um dado poluente, estabelecida com base científica, que visa evitar, prevenir ou reduzir efeitos prejudiciais à saúde humana e/ou o ambiente como um todo (MMA, 2012).

A diferença entre esses valores é basicamente:

- Valores - limite: Se tornam obrigatórios a partir da data em que entram em vigor

- Valores - alvo: Devem ser atendidos (na medida do possível) até a data estipulada, não tendo o grau de obrigatoriedade dos valores - limite.

Atualmente, a legislação da União Europeia estabelece padrões de qualidade do ar para $\mathrm{MP}_{2,5}, \mathrm{MP}_{10}$ e $\mathrm{SO}_{2}, \mathrm{NO}_{2}, \mathrm{CO}, \mathrm{O}_{3}$, Benzeno, Chumbo, 
Arsênio, Cádmio, Níquel e HPA ,cujos valores estão sumarizados na Tabela .5

Tabela 5 - Padrões Europeus de Qualidade do Ar

Valor-limite

Valor-alvo

\begin{tabular}{|c|c|c|c|c|c|}
\hline \multirow[b]{2}{*}{ Poluente } & \multirow[b]{2}{*}{ Concentração } & & \multirow[b]{2}{*}{$\begin{array}{l}\text { Período de } \\
\text { Amostragem }\end{array}$} \\
\hline & & $\begin{array}{c}\text { Data de } \\
\text { Atendimento }\end{array}$ & Concentração & $\begin{array}{c}\text { Data de } \\
\text { Atendimento }\end{array}$ & \\
\hline \multirow{2}{*}{$\mathrm{MP}_{2,5}$} & $25 \mu \mathrm{g} / \mathrm{m}^{3}$ & $1 / 12015$ & $\begin{array}{c}25 \\
\mu \mathrm{g} / \mathrm{m}^{3}\end{array}$ & $1 / 1 / 2010$ & \multirow[t]{2}{*}{1 ano } \\
\hline & $20 \mu \mathrm{g} / \mathrm{m}^{3}$ & $1 / 1 / 2020$ & - & - & \\
\hline \multirow{2}{*}{$\mathrm{MP}_{10}$} & $50 \mu \mathrm{g} / \mathrm{m}^{3}$ & $1 / 1 / 2005$ & - & - & $24 \mathrm{~h}$ \\
\hline & $40 \mu \mathrm{g} / \mathrm{m}^{3}$ & $1 / 1 / 2005$ & - & - & 1 ano \\
\hline \multirow{2}{*}{$\mathrm{SO}_{2}$} & $350 \mu \mathrm{g} / \mathrm{m}^{3}$ & $1 / 1 / 2005$ & - & - & 1 ano \\
\hline & $125 \mu \mathrm{g} / \mathrm{m}^{3}$ & $1 / 1 / 2005$ & - & - & $24 \mathrm{~h}$ \\
\hline \multirow{2}{*}{$\mathrm{NO}_{2}$} & $200 \mu \mathrm{g} / \mathrm{m}^{3}$ & $1 / 1 / 2010$ & - & - & $1 \mathrm{~h}$ \\
\hline & $40 \mu \mathrm{g} / \mathrm{m}^{3}$ & $1 / 1 / 2010$ & - & - & 1 ano \\
\hline CO & $10 \mu \mathrm{g} / \mathrm{m}^{3}$ & $1 / 1 / 2005$ & - & - & $\begin{array}{c}\text { Média máxima } \\
\text { diária por } \\
\text { períodos de } 8 \\
\text { horas }\end{array}$ \\
\hline
\end{tabular}

\begin{tabular}{|c|c|c|c|c|c|}
\hline $\mathrm{O}_{3}$ & - & - & $\begin{array}{c}120 \\
\mu \mathrm{g} / \mathrm{m}^{3(\mathrm{a})}\end{array}$ & $1 / 1 / 2010$ & $\begin{array}{c}\text { Média máxima } \\
\text { diária por } \\
\text { períodos de } 8 \\
\text { horas }^{(b)}\end{array}$ \\
\hline & - & - & $\begin{array}{l}18.000 \\
\mu \mathrm{g} / \mathrm{m}^{3} / \\
\mathrm{m}^{3} \cdot \mathrm{h}^{(\mathrm{b})}\end{array}$ & $1 / 1 / 2010$ & $\begin{array}{l}\text { Maio a julho } \\
\text { num período } \\
\text { de } 5 \text { anos }\end{array}$ \\
\hline Benzeno & $5 \mu \mathrm{g} / \mathrm{m}^{3}$ & $1 / 1 / 2010$ & - & - & 1 ano \\
\hline Chumbo & $0,5 \mu \mathrm{g} / \mathrm{m}^{3}$ & $1 / 1 / 2005$ & - & - & - \\
\hline Arsênio & - & - & $6 \mathrm{ng} / \mathrm{m}^{3}$ & $31 / 12 / 2012$ & 1 ano \\
\hline Cádmio & - & - & $5 \mathrm{ng} / \mathrm{m}^{3}$ & $31 / 12 / 2012$ & 1 ano \\
\hline Níquel & - & - & $20 \mathrm{ng} / \mathrm{m}^{3}$ & $31 / 12 / 2012$ & 1 ano \\
\hline HPA & - & - & $1 \mathrm{ng} / \mathrm{m}^{3}$ & $31 / 12 / 2012$ & 1 ano \\
\hline
\end{tabular}

Fonte: Adaptado Ministério do Meio Ambiente.

(a) Este valor-alvo tem como objetivo a proteção da saúde humana.

(b) Este valor-alvo tem como objetivo a proteção da vegetação. 


\section{MATERIAIS E MÉTODOS}

Neste item estão descritas as características da área de estudo bem como seus dados de maior relevância. Na sequência serão apresentadas as questões relacionadas ao tipo de fontes emissoras que abrangem o inventário e o procedimento de escolha dos setores inventariados. Em seguida é apresentada a descrição das atividades, processos e produtos químicos utilizados, a relação de poluentes inventariados e base de referência para os fatores de emissão assumidos nos cálculos.

\subsection{Domínio do inventário (Caracterização da Área de Estudo)}

O Instituto de Pesquisas Energéticas e Nucleares - IPEN é uma autarquia do Governo do Estado de São Paulo, vinculada à Secretaria de Desenvolvimento. É gerenciado técnica, administrativa e financeiramente pela Comissão nacional de Energia Nuclear - CNEN (DOU 25.07.2012), e associado para fins de ensino de pós-graduação à Universidade de São Paulo. Fica localizado no campus da Universidade de São Paulo - USP, estabelecido à Av. Prof. Lineu Prestes, № 2.242 - Cidade Universitária - "Armando de Salles Oliveira”, Butantã, no Município e Estado de São Paulo (Figura 2) (Apêndice B), inscrito no CNPJ sob o no 00402552/0005-50. Ocupando uma área de 500.000 $\mathrm{m}^{2}$ dispõe dos mais modernos equipamentos, alguns desenvolvidos no próprio instituto, e conta com profissionais de elevado grau de especialização, que no desempenho de suas atividades, promovem esse Instituto a uma posição de destaque em vários setores da atividade nuclear entre elas, as aplicações das radiações e radioisótopos, em reatores nucleares, em materiais, no ciclo do combustível e em radioproteção e dosimetria (CNEN, 2013). 
Figura 2 - Localização do IPEN no campus da USP

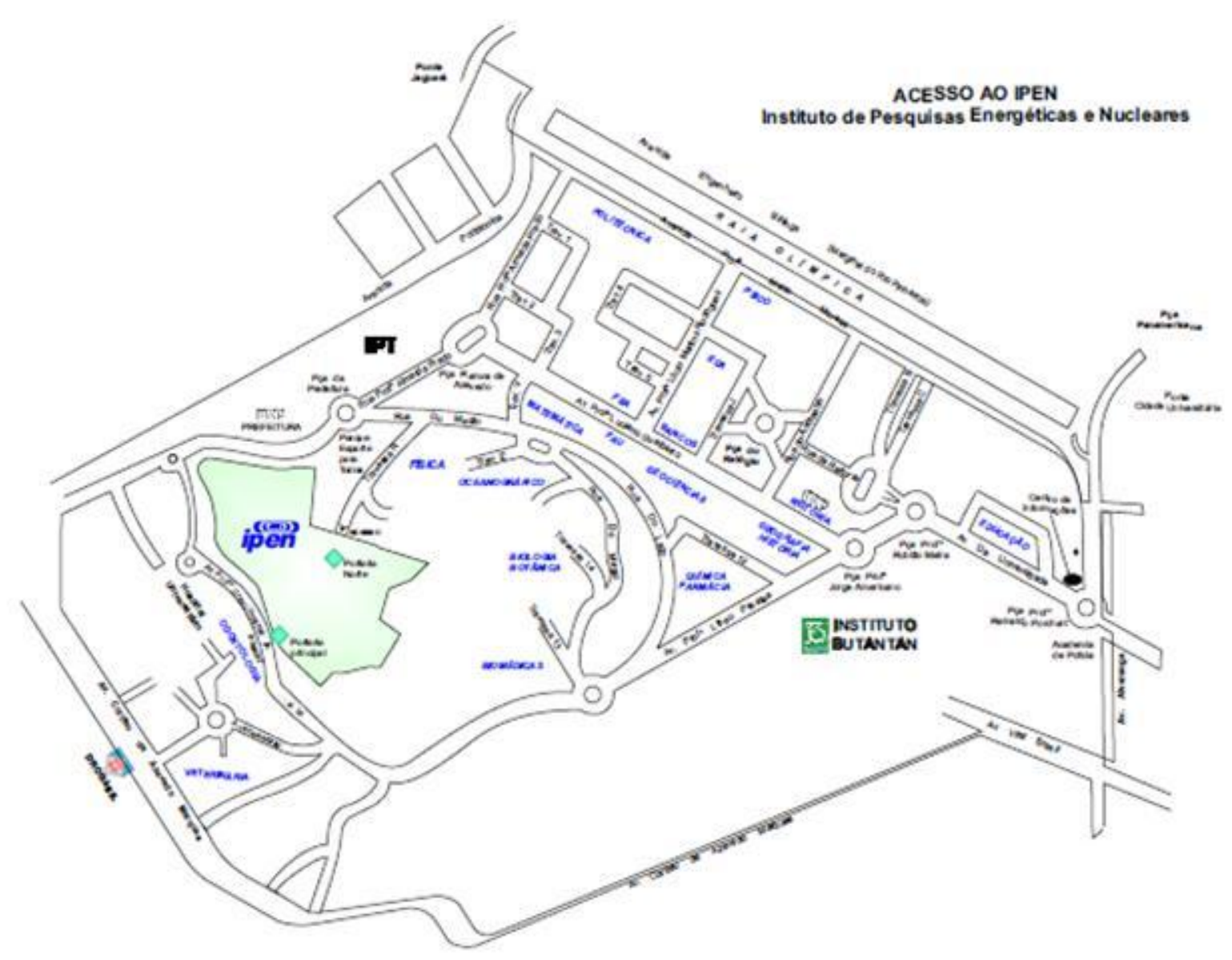

Fonte: www.ipen.br.

Tem uma destacada atuação em vários setores da atividade nuclear, entre elas, nas aplicações das radiações e na produção de radioisótopos \& radiofármacos, em reatores nucleares, em materiais e no ciclo do combustível, em radioproteção e dosimetria, cujos resultados vêm proporcionando avanços significativos no domínio de tecnologias, na produção de materiais e na prestação de serviços de valor econômico e estratégico para o país, possibilitando estender os benefícios da energia nuclear a segmentos maiores de nossa população.

O IPEN possui em seu organograma (Figura 3), um Conselho Superior que propõe medidas para o cumprimento das diretrizes da instituição junto a Comissão Nacional de Energia Nuclear - CNEN, um conselho técnico administrativo composto de cinco diretorias: DAI - Administração e Infraestrutura; DPDE - Pesquisa, Desenvolvimento e Ensino; DPG - Planejamento e Gestão; 
DPS - Produtos e Serviços e DS - Segurança, que compõem as áreas administrativas. A Diretoria de Segurança é formada por quatro gerências: GRM - Metrologia das Radiações; GRA - Radiometria Ambiental; GRP Radioproteção e GRR - Rejeitos Radioativos. Há também, a superintendência e a área técnica de P\&D que são formadas por 11 Centros (ou unidades) de pesquisa (www.ipen.br): CB - Centro de Biotecnologia; $\mathrm{CCCH}$ - Célula a Combustível e Hidrogênio; CCN - Combustível Nuclear; CCTM - Ciências dos Materiais; CEI- Ensino e Informação; CEN- Engenharia Nuclear; CLA - Laser e Aplicações; CQMA - Química e Meio Ambiente; CR - Radiofarmácia; CRPqReator de Pesquisas e CTR - Tecnologia das Radiações.

Figura 3 - Organograma do Instituto de Pesquisa Energéticas e Nucleares IPEN

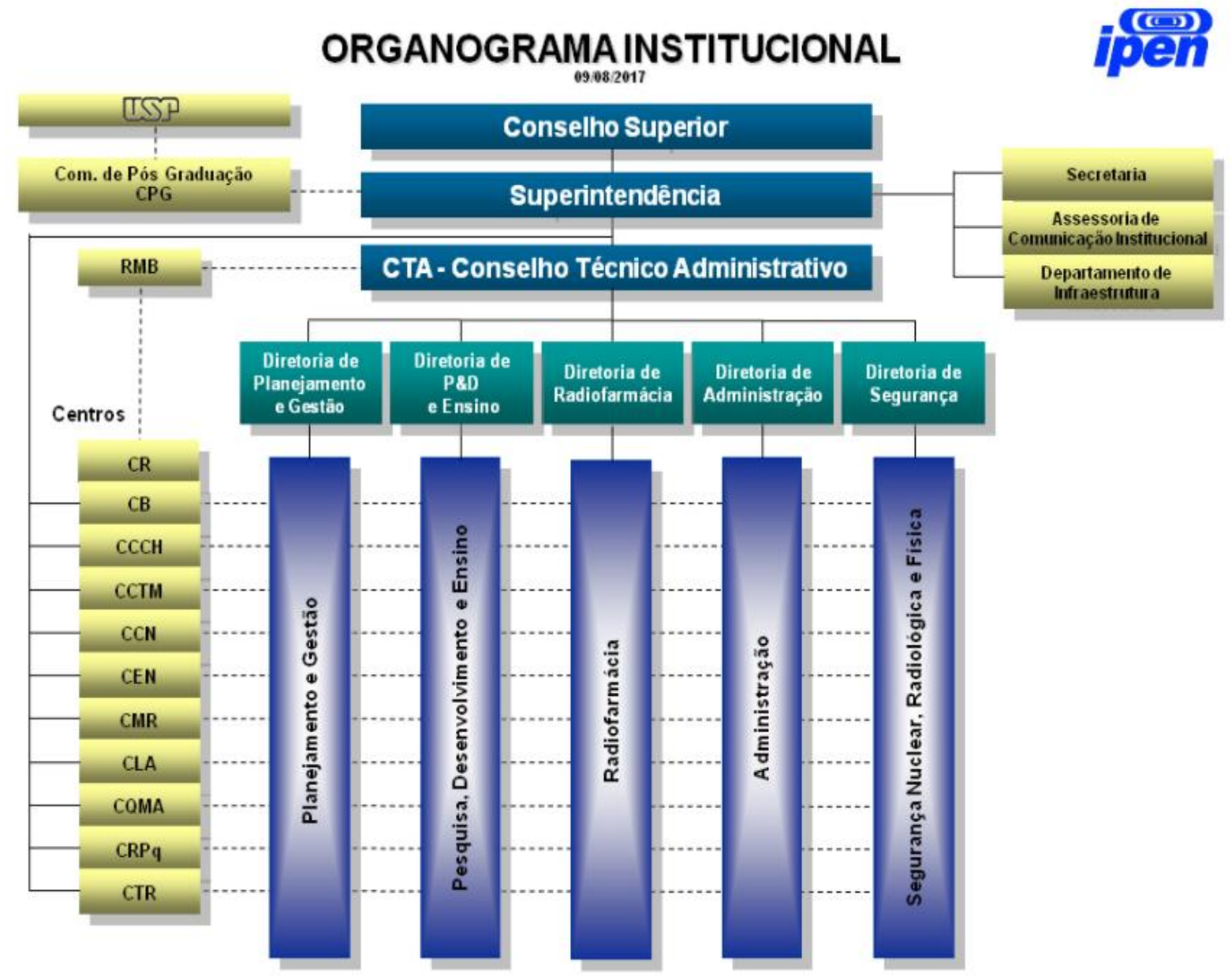

Fonte: Adaptado do site: www.ipen.br (março de 2017). 
Atualmente no IPEN os impactos ambientais não radiológicos são identificados levando em consideração as entradas e saídas associadas às atividades, processos e operações dos centros do IPEN. Estes impactos são identificados por meio do monitoramento dos efluentes líquido lançado em rede coletora de esgoto, cuja característica é a de ser não radioativo, de composição predominantemente sanitária do IPEN e por meio do monitoramento de água subterrânea em seu campus, onde são avaliados os parâmetros estabelecidos nas Resoluções CONAMA no 430/2011 completa e altera as Resoluções no 357/05 e 397/08 e Portaria no 2914/2011 do Ministério da Saúde (IPEN, 2013a).

Dentro do Programa de Gerenciamento Ambiental no campus do IPEN, várias ações e atividades são desenvolvidas visando atender as legislações ambientais vigentes e as condicionantes de sua licença ambiental de operação, entre elas as ações para minimizar a geração de resíduos e de substâncias nocivas ao meio ambiente e a saúde humana.

Quanto aos aspectos ambientais o controle operacional do campus pode ser resumido a grandes programas (Tabela 6): Controle Radiológico e Controle Não Radiológico, que incluem:

Tabela 6- Controle operacional quanto aos aspectos ambientais do IPEN Controle Radiológico Controle não Radiológico

\begin{tabular}{ll}
\hline Vigilância ambiental & Emissões atmosféricas \\
\hline Controle da radiação & Efluentes líquidos \\
\hline Controle de contaminação & $\begin{array}{l}\text { Resíduos convencionais / } \\
\text { orgânicos }\end{array}$ \\
\hline Efluentes líquidos Radioativos & Resíduos perigosos \\
\hline Efluentes gasosos Radioativos & Resíduos sanitários \\
\hline Avaliação de doses na população & Resíduos de serviço de saúde \\
\hline $\begin{array}{l}\text { Gerenciamento de resíduos de baixa } \\
\text { atividade }\end{array}$ & Resíduos inertes (reciclagem) \\
\hline $\begin{array}{l}\text { Programa de Monitoramento Radiológico } \\
\text { Ambiental (vigilância) } \\
\text { Fonte: PIRES, M. A. F. (Coord.); COTRIM, M.E.B.; SOUSA, W. H. de (Coord.) Relatório anual de } \\
\text { gestão ambiental. São Paulo: IPEN/CNEN-SP, 2016 e 2017. }\end{array}$ & $\begin{array}{l}\text { Programa de Monitoramento } \\
\text { Químico Ambiental (vigilância) }\end{array}$
\end{tabular}


A agenda ambiental do IPEN envolve ações de segurança e saúde no trabalho e várias ações e programas ambientais (Tabela 7) e todos estes, principalmente o programa de gestão de resíduos e efluentes auxiliam nos processos para minimizar os impactos de emissão atmosférica.

Tabela 7 - Programas de Controle Ambiental, segurança, prevenção e minimização de impacto ambiental.

Documentos e Programas Ambientais e de Segurança

Controle Radiológico

Programa de Proteção Radiológica - PPR

Programa de Monitoração Radiológica Ambiental - PMRA

Programa de Gerência de Rejeitos Radioativos - PGRR

Programa de Geral de Radioproteção das Instalações do IPEN - PGRP

Relatório de avaliação das doses efetivas nos grupos críticos da população decorrente da operação rotineira das instalações do IPEN

Relatório de Análise de Segurança das instalações nucleares e radioativas do IPEN - RAS

Controle não Radiológico

Programa de Monitoração Químico Ambiental - PMQA

Programa de Gerenciamento de Resíduos Químicos (Resíduos Perigosos)

- PGRC

Programa de Gerenciamento de Resíduos de Serviço de Saúde - PGRSS

Programa de Gestão de Resíduos Sólidos Comuns

Programa de Logística Sustentável (em fase de avaliação)

Programa de Comunicação Social

Programa de Educação Ambiental, em atendimento a IN 02/ 2012 do IBAMA

Requisitos regulamentares ambientais, de segurança e outros aplicados aos negócios do IPEN

Programa de Monitoramento e Controle de Emissões Atmosféricas PMEA

Parecer técnico do IBAMA - Licença de Operação - Licenciamento Ambiental - Termo de Ajustamento de Conduta - TCAC (IPEN - IBAMA)

Licença de Operação Ambiental - L.O. n 0 1325/2016 de 22/02/2016

Fonte: Relatório anual de gestão ambiental. São Paulo: IPEN/CNEN-SP, 2016 e 2017.

A multidisciplinaridade das atividades do setor nuclear tem permitido ao IPEN, conduzir um amplo e variado programa de pesquisas e desenvolvimentos em outras áreas. 
Dentre eles, o monitoramento das emissões atmosféricas não radioativas geradas no IPEN. Este monitoramento é realizado pelas medições de material particulado e gases de efeito estufa na estação de monitoramento IPEN USP da CETESB instalada dentro de seu campus, próximo a Portaria da Av. Lineu Prestes 2242. São monitorados os parâmetros $\mathrm{MP}_{2,5}, \mathrm{NO}, \mathrm{NO}_{\mathrm{x}}, \mathrm{NO}_{2}$ e $\mathrm{O}_{3}$. $\mathrm{A}$ estação fixa automática denominada "cidade universitária USP-IPEN" (Figura 4), $n^{\circ} 31$ é operada pela CETESB e está on-line na rede automática.

Figura 4 - Vista Aérea do Instituto de Pesquisa Energéticas e Nucleares - IPEN; localização da estação de monitoramento da CETESB - IPEN/USP

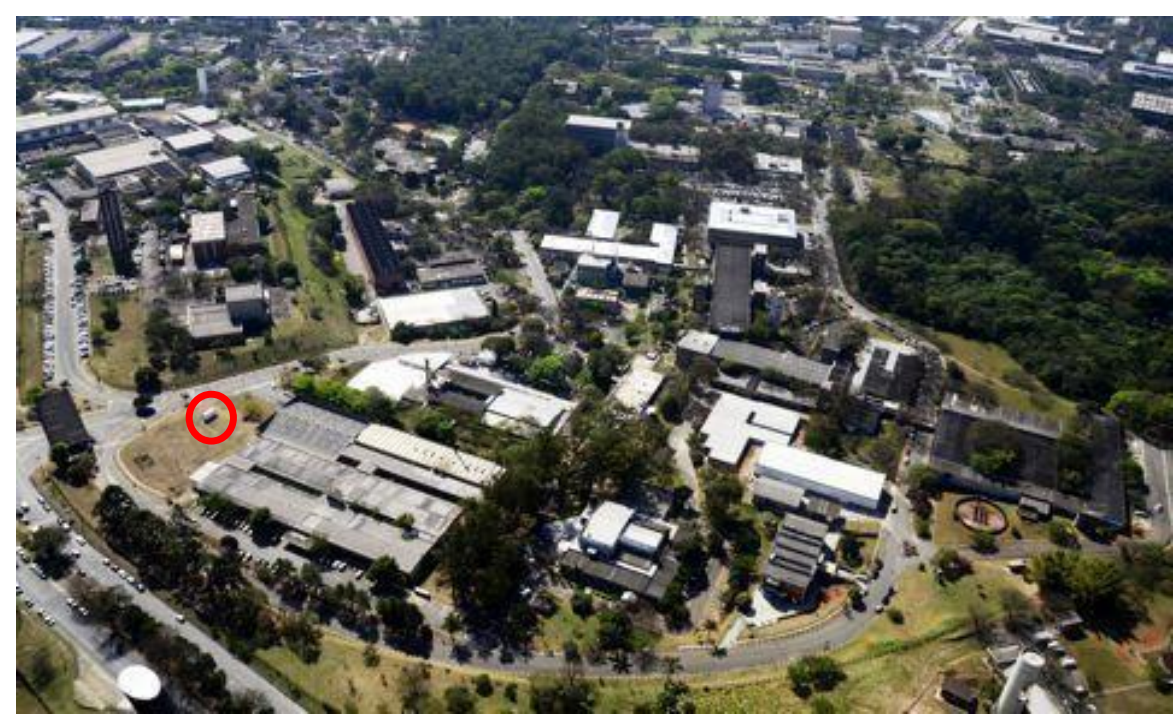

Fonte: www.ipen.br.

O ACORDO DE COOPERAÇÃO TÉCNICA - ACT, entre o IPEN e a CETESB, existente desde 2006, tem por objeto a conjugação de esforços e o desenvolvimento de atividades visando que a CETESB opere a estação de avaliação automática da qualidade do ar, situada no IPEN, nas coordenadas geográficas abaixo, em UTM (Datum WGE 84): LONGITUDE: 23K $322.680 \mathrm{E}$ LATITUDE: 7.392.709 S.

Segundo a classificação da CETESB essa rede está instalada em uma região vocacional denominada de Industrial e pertence a Unidade de Gerenciamento de Recursos Hídricos - Alto Tietê, 6 (UGRHI-6).

O boletim de qualidade do ar divulgado diariamente, às 16 horas, pela CETESB apresenta o resultado do monitoramento das últimas 24 horas para 
todos os poluentes medidos, bem como a previsão das condições de dispersão para as 24 horas seguintes.

A qualidade do ar é definida pelo poluente de maior índice registrado no dia. Apresenta também, para cada UGRHI, a totalização das qualidades N1BOA, N2-MODERADA, N3-RUIM, N4-MUITO RUIM e N5-PÉSSIMA, as condições meteorológicas presentes no dia e a previsão meteorológica para as próximas 24 horas.

Os valores diários utilizam como referência os períodos de exposição estabelecidos nos padrões de qualidade do ar, quando existentes. Além do acesso aos dados online, a CETESB emite para o IPEN um relatório anual, com as informações geradas no programa de monitoramento.

\subsection{Definição da abordagem utilizada}

A elaboração do inventário de emissões atmosféricas foi orientada pelas normas federais que tratam dos padrões de emissões atmosféricas para processos industriais: Resolução CONAMA 382/2006 e Resolução CONAMA 436/2011.

Além das Resoluções CONAMA, também foram observadas normas específicas para o estado ou município de modo que possam conter informações relevantes para elaboração deste estudo. No estado de São Paulo, por exemplo, a CETESB orienta através da Decisão de Diretoria N ${ }^{\circ}$ 010/2010/P quanto à elaboração do inventário de fontes, do Programa de Monitoramento de Emissões Atmosféricas - PMEA, bem como dispões sobre os limites de emissões atmosféricas para o estado de São Paulo.

\subsection{Escopo das Atividades Inventariadas}

O escopo das atividades inventariadas foi realizado por meio de um levantamento de dados de todos os centros de pesquisas do IPEN tendo como base um questionário previamente elaborado, tomando como base o anexo $\mathrm{B}$ da Decisão de Diretoria $N^{\circ}$ 010/2010/P. As informações foram inicialmente fomentadas pelas gerencias e os representantes ambientais das áreas (denominados no IPEN de RD- Ambientais) e validadas por esta pesquisa. 
Foram considerados para realização do inventário os parâmetros de emissões, observando a frequência de monitoramento adotada pela CETESB, para o estado de São Paulo, definidos para a indústria química: emissão de material particulado, $\mathrm{SOx}, \mathrm{NOx}, \mathrm{CO} / \mathrm{CO}_{2}$, geração de enxofre total (ERT), dioxinas e furanos; emissão de substâncias inorgânicas (metais e semi metais); fluoretos e ácido fluorídrico; amônia, hidrocarbonetos, compostos orgânicos voláteis e compostos orgânicos semivoláteis.

Na Tabela 8 são apresentados, de forma resumida, os parâmetros e frequência de monitoramento de emissões atmosféricas, para o estado de São Paulo, definidos para a indústria química, os quais foram observados no inventário.

Tabela 8 - Parâmetros e frequência de monitoramento de emissões atmosféricas para o Estado de São Paulo definidos para a indústria química

\begin{tabular}{cccccccccccc}
\hline $\begin{array}{c}\text { Indústria } \\
\text { Química }\end{array}$ & $\mathrm{MP}$ & $\mathrm{SOx}$ & $\mathrm{NOx}$ & $\mathrm{CO} / \mathrm{CO}_{2}$ & $\mathrm{ERT}$ & $\begin{array}{c}\text { Sub. } \\
\text { Inorgânicas }\end{array}$ & $\mathrm{F} / \mathrm{HF}$ & $\mathrm{NH}_{3}$ & $\mathrm{HC}$ & $\begin{array}{c}\mathrm{V} \\
\text { vOCs }\end{array}$ & D\&F \\
\cline { 2 - 9 } & $*$ & $*$ & $*$ & & & & & & & &
\end{tabular}

Frequência: $\left({ }^{*}\right)$ bienal. ERT: Enxofre Reduzido Total (ERT); D\&F: Dioxinas e Furanos; VOCCompostos orgânicos voláteis; VOCS - compostos orgânicos semivoláteis. MP: material particulado; HC: hidrocarbonetos; $\mathrm{CO} / \mathrm{CO}_{2}$ : Monóxido de carbono e dióxido de carbono; F/HF: fluoretos e ácido fluorídrico; SOx: monóxido de enxofre e NOx: monóxidos de nitrogênio.

Fonte: adaptada da Decisão de Diretoria No 10/2010/P

A Figura 5 apresenta uma descrição das etapas estabelecidas para a realização do inventário de emissões atmosféricas (CETESB, 2009). 
Figura 5 - Etapas estabelecidas para realização do inventário de emissões atmosféricas

\section{Identificar as Fontes de Emissão}

- Realizar um inventário identificando in loco todas as potenciais fontes de emissão de poluentes para a atmosfera;

- Relacionar todos os poluentes a cada fonte de emissão.

\section{Classificar as Fontes de Emissão}

- Fontes fixas ou estacionarias;

- Fontes evaporativas, fugitivas ou abertas.

\section{Definir os Métodos de Cálculos para Estimar as Emissões}

-Amostragem de chaminés

- Balanço de massa;

- Método de emissão;

- Fatores de emissão (protocolos disponíveis na literatura nacional e internacional);

- Estimativas de engenharia.

\section{Estimar as Emissões de Poluentes para a Atmosfera}

- Realizar o cálculo da estimativa de emissão em função do método adotado.

Fonte: Adaptado da CETESB, (2009).

\subsection{Metodologia de Cálculo}

A abordagem para a elaboração do cálculo de emissões fez uso dos processos:

- Mensuração Direta: levantamento da atividade, relação quantitativa dos reagentes utilizados nas fontes fixas por meio do inventário de emissões atmosféricas;

- Propriedades Físico-químicas: levantamento das características físico - químicas do (s) produto(s) utilizado (s). Ex: densidade;

- Estimativa de Emissões: Estimativa da taxa de emissão calculada a partir do fator de emissão apropriado.

O cálculo da estimativa das emissões de poluentes para a atmosfera foi orientado por critérios técnicos e referências internacionais.

Quanto às referências e critérios técnicos adotados no processo de 
inventário, foram observadas as propriedades físicas e químicas, acrescida das informações necessárias aos cálculos para as emissões.

Foram utilizados os fatores de emissão específicos para estimativa de emissões geradas em cada atividade ou processo executado nas fontes fixas utilizando como referência o estabelecido pela Agência Ambiental Americana - EPA - AP42 - U.S. Environmental Protection Agency, AP42, Volume I, Fifth Edition, January 1995 e pela CETESB, 2009.

\subsection{Fator de Emissão e Taxa de Emissão}

Para realizar os cálculos das possíveis emissões provenientes das instalações do IPEN foi assumida a base de dados estabelecida no Capítulo 8 Inorgânica da Indústria Química da "Emissions Factors \& AP 42, Compilation of Air Polluant Emission Factors". Conforme a A-42 (1995), em alguns casos, a operação é executada com um sistema fechado, o que permite pouca ou nenhuma emissão que escape para a atmosfera. As emissões que chegam à atmosfera da indústria química inorgânica em geral são gasosas e controladas por adsorção ou absorção. As estimativas de dados de emissões provenientes de processos químicos são escassas, por serem de uso não frequente $\mathrm{e}$ eventual, podendo não refletir a variabilidade das emissões no tempo. Desta forma, o fator de emissão tem sido frequentemente o melhor método para avaliar as estimativas das emissões atmosféricas, dentro de suas limitações.

Segundo a AP-42, o fator de emissão é um valor representativo que relaciona a quantidade de poluentes emitidos para a atmosfera com uma atividade potencialmente poluidora. Este fator é, usualmente, expresso em unidades de massa do poluente dividido por unidade de massa, volume, distância ou duração da atividade emissora de poluentes. O fator de emissão facilita significativamente a estimativa das emissões provenientes de várias fontes de poluição do ar, porque são médias representativas de dados disponíveis de uma determinada instalação ao longo de um prazo de qualidade aceitável.

Para o cálculo das emissões com a utilização dos fatores são necessárias algumas informações básicas, como o processo da atividade, 
especificado pelo fator de emissão; o fator de emissão correspondente a fim de transformar a informação do processo da atividade em estimativa de emissão com controle ou sem controle; e a eficiência dos mecanismos de captura e controle das emissões, quando aplicável.

A equação geral a ser aplicada para determinação dos fatores de emissão com Sistema de Controle de Poluentes é expressa na Equação 3 (EPA; 1995).

$$
E=A * E F *\left(1-\frac{E R}{100}\right)
$$

Onde:

$\mathrm{E}=$ Taxa de Emissão;

$\mathrm{A}=$ Taxa de execução da atividade;

$\mathrm{EF}=$ Fator de emissão característico da atividade;

$\mathrm{ER}=$ Eficiência do equipamento de controle de poluição utilizado, \%.

A equação simplificada é expressa pela Equação 4.

$$
E=A * E F
$$

\subsection{Medição das vazões (Anemômetro)}

A amostragem atmosférica é conduzida sobre um intervalo de tempo discreto e finito (Pires, 2005). Nesta etapa, foram realizadas as medições das características das fontes fixas, como, dimensões das capelas, velocidade do ar, vazão do ar e temperatura.

A medição da velocidade do ar nos sistemas de exaustão e nas capelas químicas bem como a temperatura do ar foi realizada com o auxílio de um Anemômetro testo 435 (Figura 6). 
Figura 6 - Foto representativa do Anemômetro e sondas (Anemômetro testo 435)

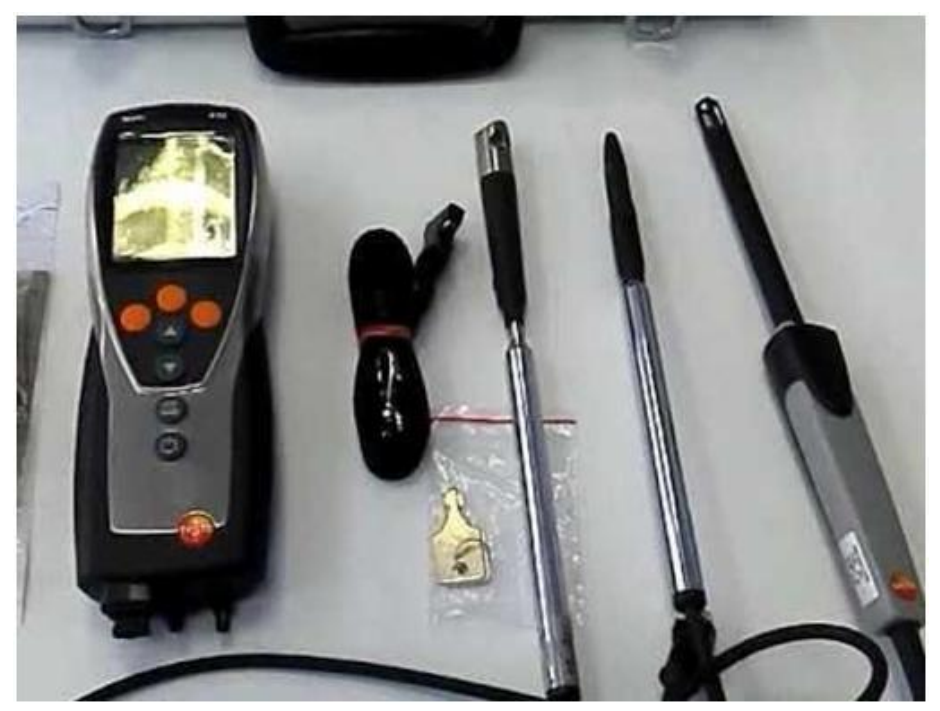

O parâmetro velocidade do ar auxiliou para o cálculo da vazão do gás, que segundo a Decisão de Diretoria № 010/2010/P a vazão de gás é a quantidade de efluente gasoso passando através de um duto ou chaminé por unidade de tempo, expressa em metros cúbicos por hora $\left(\mathrm{m}^{3} / \mathrm{h}\right)$ na condição de medição e/ou em metros cúbicos por hora, nas condições normais de temperatura e pressão $\left(\mathrm{Nm}^{3} / \mathrm{h}\right)$.

A estimativa da concentração dos poluentes foi calculada a partir da vazão encontrada e da taxa emissão calculada. Segundo a Decisão de Diretoria $N^{\circ}$ 010/2010/P, concentração é a quantidade do poluente no fluxo gasoso, expressa em miligramas por unidade de vazão de gás $\left(\mathrm{mg} / \mathrm{Nm}^{3} \mathrm{e} / \mathrm{ou} \mathrm{mg} / \mathrm{m}^{3}\right)$ ou, em correlação volumétrica (ppmv), referida às condições normais de temperatura e pressão (CNTP), em base seca e, quando aplicável, na condição referencial de oxigênio estabelecida. 


\section{RESULTADOS E DISCUSSÃO}

Neste item foram apresentados os resultados aplicando como base 0 inventário das emissões atmosféricas e em seguida aplicada a metodologia de estimativa de emissão. As estimativas de emissão se mostram como uma ferramenta de menor custo e aceita pelos órgãos ambientais, sendo um ponto de partida para futuras avaliações mais completas e de maior custo.

O estudo relativo ao inventário das fontes fixas de emissão atmosférica foi conduzido nos laboratórios do IPEN sendo avaliadas as fontes e onde seus processos possam emitir poluentes gasosos.

Foi realizado o detalhamento, a quantificação e a caracterização das fontes geradoras, a frequência e o consumo de reagentes em cada processo. $O$ método de estimativa de emissões atmosféricas foi elaborado utilizando os fatores de emissão, conforme a AP-42 (EPA, 1995) e aplicado nos centros de pesquisa do Instituto, sendo comparados com as normas e padrões estabelecidos no âmbito federal e estadual.

\subsection{Monitoramento contínuo da qualidade do ar do campus.}

Segundo os dados dos relatórios da CETESB, e de acordo com o $4^{\circ}$ relatório de acordo de cooperação IPEN CETESB, de fevereiro de 2016, considerando a série histórica e o ano de 2015, foram observados:

- Monóxido de carbono (CO): A concentração máxima de 8 horas observadas para este poluente na estação USP-IPEN, em 2015, foi de 3,1 ppm, estando portando abaixo dos padrão nacional e estadual da qualidade do ar de $\mathrm{CO}$, que é de 9 ppm - media de 8 horas.

- Dióxido de nitrogênio $\left(\mathrm{NO}_{2}\right)$ : Em 2015, concentração media de $\mathrm{NO}_{2}$ na estação USP-IPEN foi de $31 \mathrm{\mu g} / \mathrm{m}^{3}$, valor inferior ao padrão estadual de qualidade do ar de $60 \mu \mathrm{g} / \mathrm{m}^{3}$. A concentração máxima horária registrada foi de $152 \mu \mathrm{g} / \mathrm{m}^{3}$, frente a um padrão estadual de $260 \mu \mathrm{g} / \mathrm{m}^{3}$ e padrão nacional de 320 $\mu \mathrm{g} / \mathrm{m}^{3}$. 
- Ozônio $\left(\mathrm{O}_{3}\right)$ : É o poluente que mais ultrapassa o padrão de qualidade do ar na RMSP. Sendo que em 2015 o Padrão de Qualidade do $\mathrm{Ar}$ (PQAR) estadual de 8 horas de $140 \mu \mathrm{g} / \mathrm{m}^{3}$ foi excedido 26 dias. O PQAR nacional horário de $160 \mu \mathrm{g} / \mathrm{m}^{3}$ foi excedido em 53 dias. Esta estação está situada em um ponto onde não há próximo ao seu entorno, muitas fontes de emissão de precursores, sendo inferir que o ozônio medido seja resultado de transporte deste poluente em outras localidades da RMSP.

- Partículas Inaláveis finas $\left(\mathrm{MP}_{2,5}\right)$ : A máxima concentração diária de $45 \mu \mathrm{g} / \mathrm{m}^{3}$, para um padrão de curto prazo de $60 \mu \mathrm{g} / \mathrm{m}^{3}$. A Concentração média anual foi de $12 \mu \mathrm{g} / \mathrm{m}^{3}$, frente a um padrão de longo prazo de $20 \mu \mathrm{g} / \mathrm{m}^{3}$.

- Em 2015 a estação Cidade Universitária USP-IPEN funcionou praticamente sem interrupções, sendo atendida a meta estabelecida na avaliação dos poluentes regulamentados.

As Figuras 7 e 8, retiradas do site da CETESB, destacam: a medida diária do sistema de automonitoramento realizado na estação da Cidade Universitária; o mapa da qualidade do ar na rede automática e a evolução das concentrações médias de $\mathrm{NO}_{2}$ e de $\mathrm{O}_{3}$ para as estações localizadas na Região Metropolitana de São Paulo (RMSP) que apresentaram médias representativas no período de maio a setembro, nos últimos dez anos, com destaque a estação IPEN-USP. 
Figura 7 - Medida diária do sistema de auto monitoramento realizado na estação da Cid. Universitária -USP-IPEN

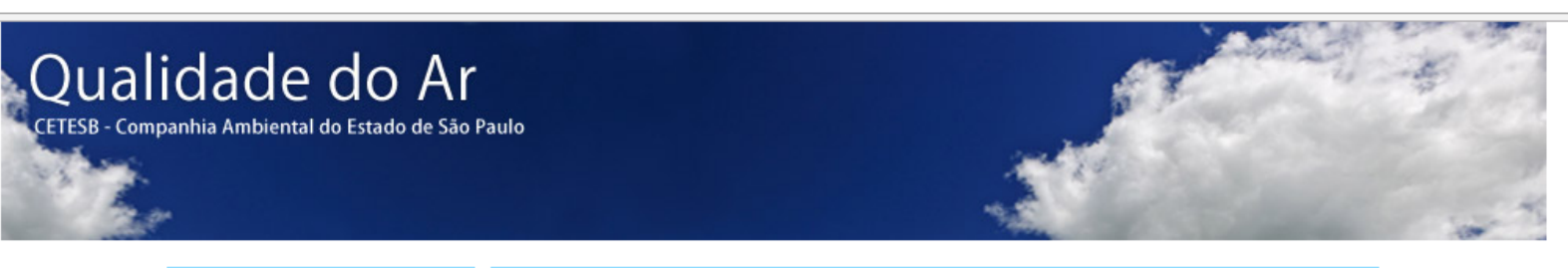

\begin{tabular}{|l||l|l|l|l} 
Ar & Qualidade do Ar " Rede Automática \\
\hline
\end{tabular}

Mapa de qualidade do ar: RMSP - Interior e Litoral | Dados horários | Resumo da última hora | Mapa de qualidade do ar: RMSP - Interior e Litoral | Dados horários | Resumo da últimá
Boletins diários: Resumo do dia - Por poluente | Configuraçẫo e localização das estaçôes

Resumo da última hora - 19/06/2017 - 10:00

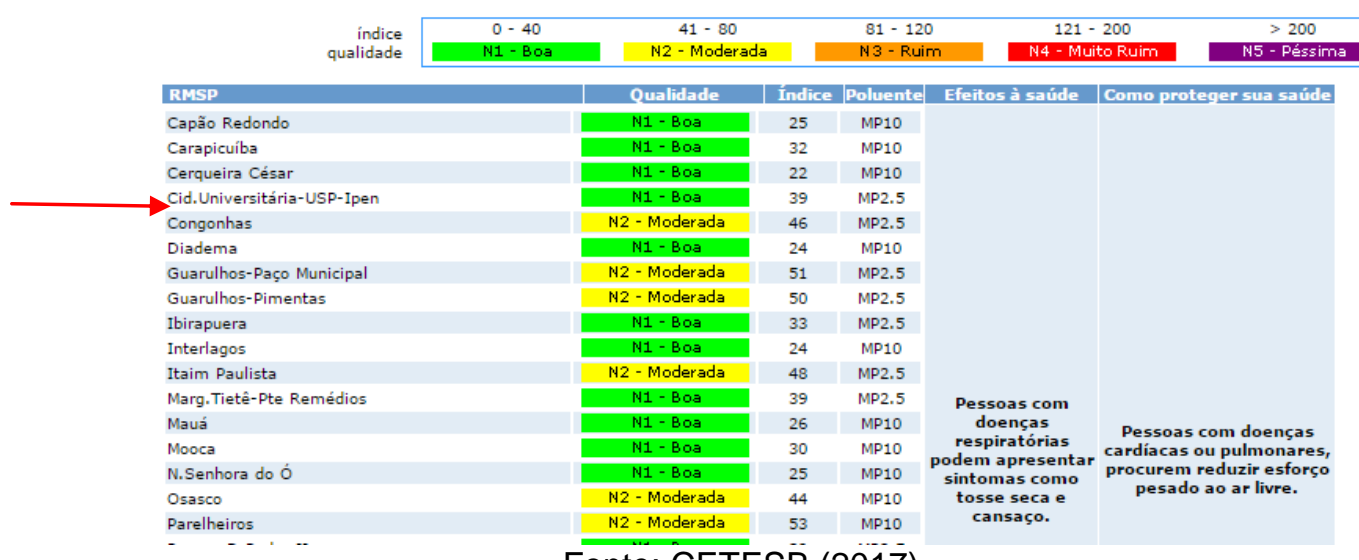

Fonte: CETESB (2017).

Fonte: CETESB̈ (2017).

Figura 8 - Mapa da qualidade do ar - rede automática - em destaque rede Cidade Universitária - USP-IPEN

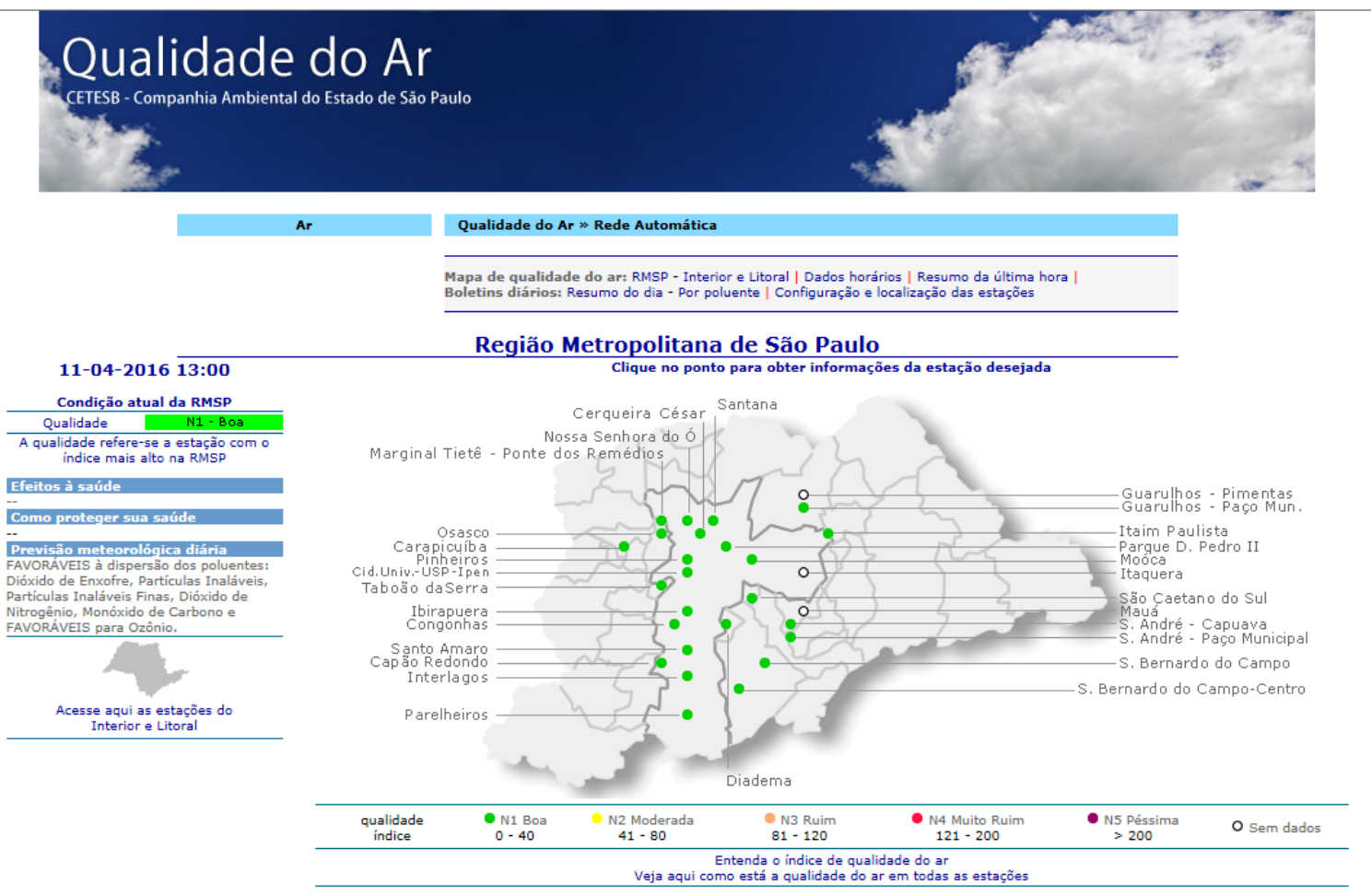

Fonte: CETESB (2017). 
Na Figura 9 (Gráfico 46, retirado do relatório da CETESB - 2016) é apresentada a evolução das concentrações médias de dióxido de nitrogênio para as estações localizadas na RMSP que apresentaram médias representativas no período de maio a setembro, nos últimos dez anos, com destaque a estação IPEN-USP.

Figura 9 - Evolução das Concentrações médias anuais de $\mathrm{NO}_{2}$ na RMSP

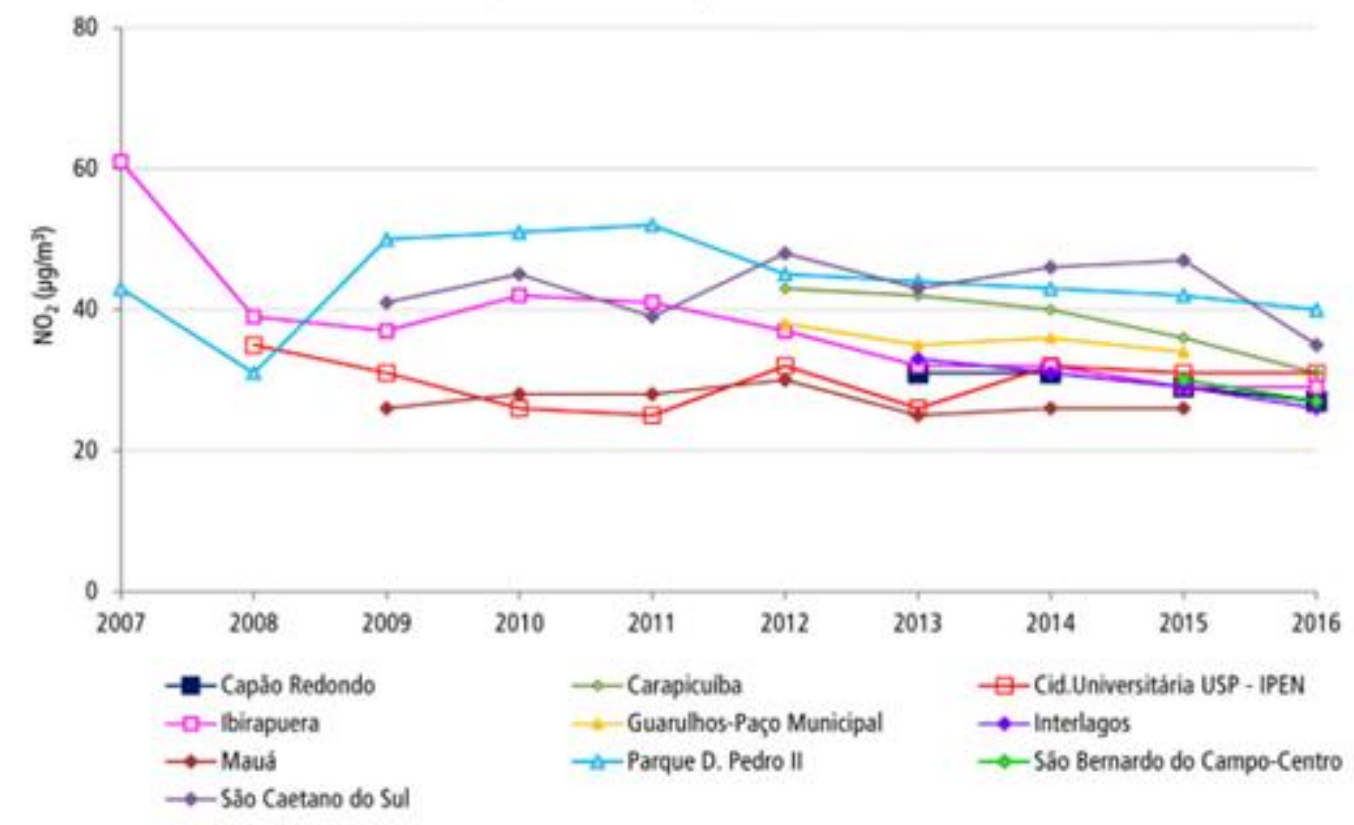

Base RMSP - Estações fixas com representatividade anual.

OBS: Em 2016, médias anuais recalculadas para Guarulhos - Paço Municipal, de 2012 a 2104. Fonte: CETSB (2016).

\subsection{Inventário das fontes de emissões}

A seguir, são apresentados os resultados aplicando como base o inventário das emissões atmosféricas e em seguida aplicada a metodologia de estimativa de emissão. As estimativas de emissão se mostram como uma ferramenta de menor custo e aceita pelos órgãos ambientais, sendo um ponto de partida para futuras avaliações mais completas e de maior custo.

O inventário realizado teve como ano-base 2015, sendo os dados coletados entre os anos de 2013 e 2017, sendo reavaliados em 2017. As áreas inventariadas no IPEN compreendem todos os laboratórios dos Centros de Pesquisa e Desenvolvimento além da Diretoria de Segurança (Apêndice B), foram identificadas as áreas e processos que geram ou com possibilidade de 
gerar emissões atmosféricas. Os Centros Ensino e Informação (CEI) e Engenharia Nuclear (CEN), em seus processos, não produzem emissões atmosféricas, portanto não foram levados em consideração. Esse inventário foi realizado com auxílio dos representantes ambientais (RD-Ambientais) de cada área de pesquisa do IPEN, bem como pelo gerente responsável.

A Tabela 9 apresenta, com base no organograma institucional e no Plano Diretor do IPEN, as principais atividades realizadas em cada unidade geradora (centros de pesquisas).

Tabela 9 - Inventário das principais atividades, realizado por centros e processos produtivos, visando à identificação das fontes fixas de emissão atmosférica no IPEN

\begin{tabular}{|c|c|c|c|c|c|c|c|c|}
\hline \multirow{3}{*}{$\begin{array}{l}\text { Unidades } \\
\text { Geradoras } \\
\text { (Centros) }\end{array}$} & \multicolumn{8}{|c|}{ Descrição dos Principais Processos Produtivos } \\
\hline & \multicolumn{3}{|c|}{ Materiais } & \multirow{2}{*}{$\begin{array}{l}\text { Processo } \\
\text { Químico }\end{array}$} & \multirow[b]{2}{*}{ Nuclear } & \multirow{2}{*}{$\begin{array}{c}\text { Farmacêutica e } \\
\text { Biológica }\end{array}$} & \multirow{2}{*}{$\begin{array}{c}\text { Petroquímica e } \\
\text { biomassa }\end{array}$} & \multirow[b]{2}{*}{ Motogerador } \\
\hline & Metálicos & Cerâmicos & Poliméricos & & & & & \\
\hline $\mathrm{CB}$ & & & & $\mathrm{X}$ & & $\mathrm{X}$ & & $\mathrm{X}$ \\
\hline $\mathrm{CCCH}$ & & & & & & & $\mathrm{X}$ & $\mathrm{X}$ \\
\hline CCTM & $\mathrm{X}$ & $\mathrm{X}$ & $\mathrm{X}$ & & & & & $\mathrm{X}$ \\
\hline CCN & & $\mathrm{X}$ & & $\mathrm{x}$ & $\mathrm{x}$ & & & $\mathrm{x}$ \\
\hline $\mathrm{CLA}\left({ }^{* *}\right)$ & & & & $\mathrm{x}$ & & & & $\mathrm{X}$ \\
\hline CQMA & & & $\mathrm{X}$ & $\mathrm{X}$ & $\mathrm{X}$ & & $\mathrm{X}$ & - \\
\hline $\mathrm{CR}$ & & & & $\mathrm{X}$ & $\mathrm{X}$ & $\mathrm{X}$ & & $X$ \\
\hline $\mathrm{CRPq}$ & & & & & $\mathrm{X}$ & & & $X$ \\
\hline CTR & & & $X$ & $X$ & $X$ & & & $X$ \\
\hline DS $\left(^{*}\right)$ & & & & & & & $x$ & $x$ \\
\hline
\end{tabular}

CB: Centro de Biotecnologia; $\mathrm{CCCH}$ : Centro de Células a Combustível e Hidrogênio; CCN: Centro do Combustível Nuclear; CLA: Centro de Lasers e Aplicações; CQMA: Centro de Química e Meio Ambiente; CR: Centro de Radiofarmácia; CRPq: Centro do Reator de Pesquisas; CTR: Centro de Tecnologia das Radiações.

$\left({ }^{*}\right)$ DS: A Diretoria de Segurança possui três Gerências com fontes fixas de Poluição: GRA, GRP e GRR, porém as duas primeiras não utilizam os reagentes químicos e a última possui Sistema de Remoção e/ou Controle de Poluentes Atmosféricos: Filtros HEPA/Filtros carvão ativado.

$\left.{ }^{* *}\right)$ processos físicos, físico-químicos e utilização de lasers de alta potência.

Considerando as atividades desenvolvidas habitualmente e atualmente no IPEN, a inspeção realizada em suas instalações e documentação pertinente, as fontes classificadas como fixas significativas ou pouco significativas de emissão existentes por centro são capelas de exaustão de gases, coifas e 
exaustores.

Neste estudo não foram levados em consideração as emissões geradas pelos motogeradores, que somam no total 17 unidades, devido à adequação com normas específicas. Cabe ressaltar que todos os motogeradores estão sendo substituídos por sistemas mais modernos e o processo de substituição está sendo realizado e gerenciado de acordo com as normas ambientais existentes.

No levantamento de dados para a elaboração do inventário (Decisão de Diretoria $n^{\circ}$ 010/2010/P), foram observados e identificados: os laboratórios de cada centro de pesquisa gerador de emissão atmosférica, sendo realizada uma descrição sucinta do processo produtivo sob ponto de vista de geração de poluentes atmosféricos, identificando se a atividade gera/libera poluentes atmosféricos; identificando as fontes fixas; os produtos químicos ou reagentes utilizados $\left(\mathrm{HNO}_{3}, \mathrm{HCl}, \mathrm{H}_{2} \mathrm{SO}_{4}, \mathrm{H}_{3} \mathrm{PO}_{4}, \mathrm{HF}, \mathrm{H}_{3} \mathrm{ClO}_{4}\right)$ que geram gases acidificantes (GA); ou $\mathrm{NH}_{3} / \mathrm{NH}_{4} \mathrm{OH}$; entres outros, e respectivo consumo (Litros mês $^{-1}$ ), com vistas à geração de poluentes atmosféricos, partículas em suspensão, metais pesados e gases de efeito estufa (GEE), (SOx, NOx, $\left.\mathrm{CO} / \mathrm{CO}_{2}, \mathrm{VOC} / \mathrm{VOCS}, \mathrm{MP}_{10}\right)$; identificando a existência de sistema de remoção e/ou controle de poluentes de emissões atmosféricas (filtros, lavadores, monitoramento), conforme modelo de planilha apresentado na Tabela 10. Esse inventário possibilitou gerar um modelo de informação de caráter geral sobre as emissões de poluentes atmosféricos no campus do IPEN. (Modelo no Apêndice C).

As informações (inventário) relativas a cada centro de pesquisa foram inseridas em um banco de dados e organizados, utilizando um sistema de planilha Excel, a fim de calcular a taxa de emissão de cada poluente.

Vale ressaltar que os dados coletados se referem ao total de reagentes consumidos ou utilizados nos processos, sendo considerado que todo 0 reagente utilizado fosse convertido em emissão gasosa levando em conta um período de 8 horas por dia e 5 dias da semana.

Deve ser observado que os laboratórios do IPEN se destinam 
basicamente a atividades de P\&D nas áreas nuclear e correlatas, portanto a sua atividade de processos não são realizadas de modo constante e continuo (40 horas semana/ 20 dias por mês), demonstrando que os dados de consumo foram extrapolados ou superestimados quanto a sua emissão.

O inventário demonstrou que os reagentes ácidos, que geram gases acidificantes (GA), são os produtos químicos de maior consumo nos processos de produção das unidades geradoras de emissão atmosféricas do IPEN. Foi observado também que são utilizados, apesar de pequeno volume, uma grande variedade de compostos químicos orgânicos. Levando em consideração que o IPEN é um instituto de P\&D, os centros com maiores capacidades produtivas possuem sistemas de controle e/ou remoção de poluentes.

Quanto aos equipamentos de controle da poluição (ECP), O IPEN, possui sistemas de remoção e/ou controle de poluentes de emissões atmosféricas, como, lavadores de gases e filtros, instalados em áreas específicas, onde envolve a manipulação de materiais radioativos e/ou pós ou processos envolvendo grandes volumes de emissões. 
Tabela 10 - Modelo do levantamento das informações das fontes fixas de poluição

\begin{tabular}{|c|c|c|c|c|c|c|c|c|c|c|c|c|c|c|c|c|c|c|c|c|c|c|c|}
\hline \multicolumn{7}{|c|}{$\begin{array}{l}\text { Identificação } \\
\text { do gerador e } \\
\text { descrição } \\
\text { fontes }\end{array}$} & \multicolumn{9}{|c|}{$\begin{array}{l}\text { Frequência de uso: } \\
\text { Identificação de produtos utilizados e } \\
\text { respectivo consumo } \\
\left(\text { L.mês }{ }^{-1}\right)\end{array}$} & \multicolumn{6}{|c|}{$\begin{array}{c}\text { Identificação dos poluentes } \\
\text { atmosféricos }\end{array}$} & \multicolumn{2}{|c|}{$\begin{array}{l}\text { Identificação de } \\
\text { sistemas de } \\
\text { remoção e /ou } \\
\text { controle de } \\
\text { poluentes }\end{array}$} \\
\hline 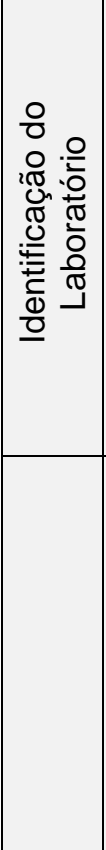 & 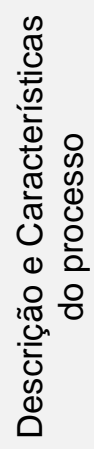 & 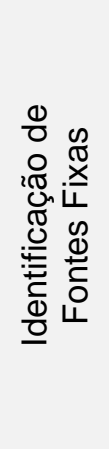 & 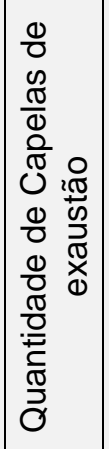 & \multicolumn{3}{|c|}{ 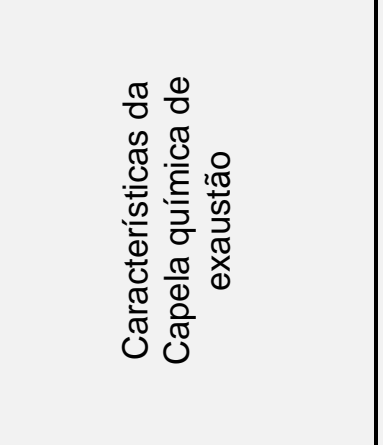 } & \multicolumn{7}{|c|}{$\frac{\infty}{0}$} & $\begin{array}{l}\frac{0}{\sqrt[N]{\overparen{N}}} \\
\frac{\mathcal{O}}{4}\end{array}$ & 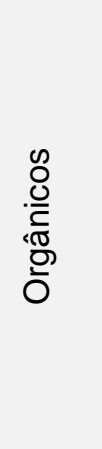 & O) $^{x}$ & $0^{x}$ & $\begin{array}{l}O^{N} \\
\text { O } \\
\end{array}$ & 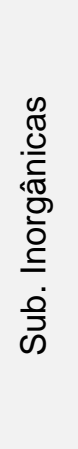 & 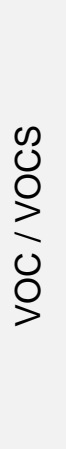 & $\begin{array}{l}\frac{0}{亠^{\prime}} \\
\frac{1}{\Sigma}\end{array}$ & 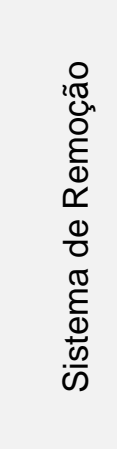 & 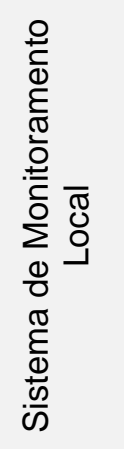 \\
\hline
\end{tabular}

Fonte: Adaptado da Decisão de Diretoria № 010/2010/P. 
O inventário e os modelos de cálculo foram detalhados utilizando como fonte de dados as informações dos laboratórios do Centro de Química e Meio Ambiente. Em seguida serão apresentados e discutidos os resultados das demais áreas.

\subsection{Centro de Química e Meio Ambiente}

Descrição e características do processo ou da unidade geradora: Um dos objetivos do Centro de Química e Meio Ambiente é o desenvolvimento de novas tecnologias na área química e química ambiental com foco na aplicação de uma estratégia integrada e preventiva de processos, produtos e serviços, em apoio às políticas públicas ambientais e ações de diagnóstico ambiental e gerenciamento ambiental de suas instalações. O centro desenvolve também pesquisas nas áreas de tecnologia de polímeros, nanomateriais, biomateriais e caracterização de materiais nucleares para as áreas médica, indústria nacional, indústria nuclear. As atividades do CQMA estão voltadas para a formação e o aperfeiçoamento de recursos humanos, para o desenvolvimento científico e tecnológico e a prestação de serviços de alto cunho tecnológico, nas áreas de tecnologia química e nuclear, meio ambiente, química ambiental e química nuclear. O CQMA possui atualmente 12 laboratórios destinados a P\&D, dos quais dois deles com Sistema da Qualidade implantado segundo as normas ABNT NBR ISO-17.025 (Laboratório de Fluorescência de Raios X; Laboratório de Análises Química e Ambiental).

A seguir é realizada uma breve descrição das atividades de cada um dos 12 laboratórios quanto ao processo produtivo sob ponto de vista de geração de poluentes atmosféricos.

- Laboratório de Tecnologias Alternativas de Refino: Nesse laboratório há dois processos químicos que têm a emissão de $\mathrm{H}_{2} \mathrm{~S}$, na retificação das amostras e sistema reacionário, com microondas, sendo que toda a emissão do gás está direcionada para um sistema de lavagem de gases Esse laboratório possui quatro (4) sistemas de lavadores específicos e filtros metálicos ligados ao processo, sendo um sistema de absorção de gás para $\mathrm{H}_{2} \mathrm{~S}$ - modelo LG 95-300TUSV e um sistema de filtros metálicos com água, ligados ao processo, e um 
sistema de controle de processo com verificação de $\mathrm{pH}$ da solução do sistema de absorção.

- Laboratório de Nanotecnologia Molecular: As operações unitárias envolvidas são basicamente tratamento de amostras para análise química: (pesagem/dissolução de amostra/pré-concentração por extração com solventes) e determinação instrumental ou via úmida. Dissolução da Amostra: As amostras são dissolvidas na presença de soluções ácidas ou básicas. O processo ocorre após a pesagem diretamente sobre a amostra em uma capela de exaustão de gases ou no sistema de digestão por micro-ondas sob exaustão. Os principais compostos químicos utilizados nessa dissolução são: ácido nítrico; ácido clorídrico, eventualmente ácido sulfúrico, ácido fosfórico e/ou perclórico. Todos os reagentes são utilizados em quantidades extremamente pequenas (1 a $5 \mathrm{~mL}$ ) por processos. Eventualmente são evaporados nas capelas solventes provenientes de processos de extração ou de pré-concentração, onde pode ocorrer a emissão de compostos orgânicos voláteis (VOC), provenientes da evaporação dos solventes: acetonitrila, metanol. As emissões destas etapa são provenientes da evaporação dos ácidos ou dos solventes: Óxidos de Enxofre (SOx), Óxidos de Nitrogênio (NOx), não são emitidos Monóxido de Carbono (CO) e Hidrocarbonetos $(\mathrm{HC})$.

- Laboratório de Química e Eletroquímica: No laboratório há o desenvolvimento de processos e recuperação de metais em efluentes líquidos. São utilizados absorvedores, trocadores iônicos ou processos eletroquímicos.

- Laboratório de Processos Térmicos e de Decomposição de Rejeitos: Esse laboratório desenvolve pesquisas com sais fundidos e possui sistema de controle atmosférico.

- Laboratório de Síntese e Caracterização de Polímero: As operações unitárias envolvidas no laboratório são: preparação de membranas poliméricas pela técnica de enxertia (solução líquida de estireno e solvente orgânico); lavagem com tolueno ou acetona destas membranas; reações de sulfonação (realizadas nas capelas e sob o sistema de exaustão). Os solventes orgânicos utilizados são: tolueno, acetona, álcool isopropílico, dicloroetano 
sendo utilizados cerca de $200 \mathrm{~mL}$ por processo.

- Laboratório de Biomateriais Poliméricos: As atividades realizadas no laboratório são basicamente o desenvolvimento de novos polímeros naturais

- Laboratório Análises Química e Ambiental - LAQA: As operações unitárias envolvidas nos laboratórios de análises químicas são basicamente: preparação previa da amostra (pesagem/dissolução de amostra / pré-concentração por extração com solventes) e determinação instrumental ou via úmida. DISSOLUÇÃO DA AMOSTRA: As amostras são dissolvidas na presença de soluções ácidas ou básicas. O processo ocorre após a pesagem diretamente sobre a amostra em uma capela de exaustão de gases ou no sistema de digestão por micro-ondas sob exaustão. Os principais compostos químicos utilizados nessa dissolução são: ácido nítrico; ácido clorídrico, eventualmente ácido sulfúrico, ácido fosfórico e/ou perclórico. Todos os reagentes são utilizados em quantidades extremamente pequenas (1 a $5 \mathrm{~mL}$ ) por processos. As emissões destas etapas são provenientes da evaporação dos ácidos ou dos solventes: Emissões de Óxidos de Enxofre $\left(\mathrm{SO}_{\mathrm{x}}\right)$, Óxidos de Nitrogênio $\left(\mathrm{NO}_{\mathrm{x}}\right)$, Monóxido de Carbono (CO) e Hidrocarbonetos ( $\mathrm{HC}$ ) não ocorrem.

- Laboratório de Caracterização Química: As atividades realizadas no laboratório são basicamente: preparação prévia da amostra (pesagem/dissolução de amostra) e determinação instrumental (HR-ICP/MS; AAS, HPLC/UV visível e GCMS). As amostras são preparadas por dissolução na presença de soluções ácidas, em uma capela de exaustão, ou fusão em mufla sob exaustão. Os principais ácidos utilizados nessa dissolução são nítrico, clorídrico, sulfúrico e eventualmente fluorídrico e/ou perclórico. As emissões desta etapa são provenientes da evaporação dos ácidos ou dos solventes.

- Laboratório Fluorescência de Raios X (LFRX): As atividades realizadas nos laboratórios são basicamente: preparação prévia da amostra (pesagem/dissolução de amostra / prensagem de amostra) e determinação instrumental (FR-X). As amostras são preparadas por dissolução na presença de 
soluções ácidas ou básicas, em uma capela de exaustão, ou por fusão em mufla sob exaustão. Os principais ácidos utilizados nessa dissolução são nítrico, clorídrico e eventualmente sulfúrico, fluorídrico e/ou perclórico. As emissões são provenientes da evaporação dos ácidos e solventes durante a preparação das amostras.

- Laboratório de Ecotoxicologia: os processos de preparo e de manutenção dos ensaios aplicados no laboratório não geram emissões gasosas.

- Laboratório de Química de Solos e Processos de Adsorção -

LQSA: As atividades realizadas nos laboratórios são basicamente a preparação prévia da amostra para estudo de adsorção. Os principais ácidos utilizados são os ácidos nítrico, clorídrico e sulfúrico. As emissões desta etapa são provenientes das reações durante a preparação da amostra e do estudo de adsorção. As emissões são provenientes da evaporação dos ácidos durante a preparação das amostras.

Foram observados nos dados inventariados que o CQMA possui 84 fontes fixas instaladas em diferentes salas laboratoriais pertencentes a seis prédios (30, 31, 33, 67, 98 e 100), (Figura 10), destas, a maioria utiliza ácidos, álcalis e/ou orgânicos, há sistemas de controle e/ou remoção de poluentes (filtros HEPA) instalados nas salas do Laboratório de Caracterização Química e no Laboratório de Processos Térmicos de Decomposição de Rejeitos. O laboratório de Tecnologias Alternativas de Refino - LABTAR (Prédio 98), em seu processo produtivo não utiliza estes reagentes descritos e possui uma central de tratamento de gases.

A Tabela 11 apresenta os resultados referentes ao inventário de reagentes químicos utilizados em 09 dos 12 laboratórios do Centro de Química e Meio Ambiente. 
Figura 10 - Distribuição de fontes fixas por prédio que compõe o Centro de Química e em Meio Ambiente

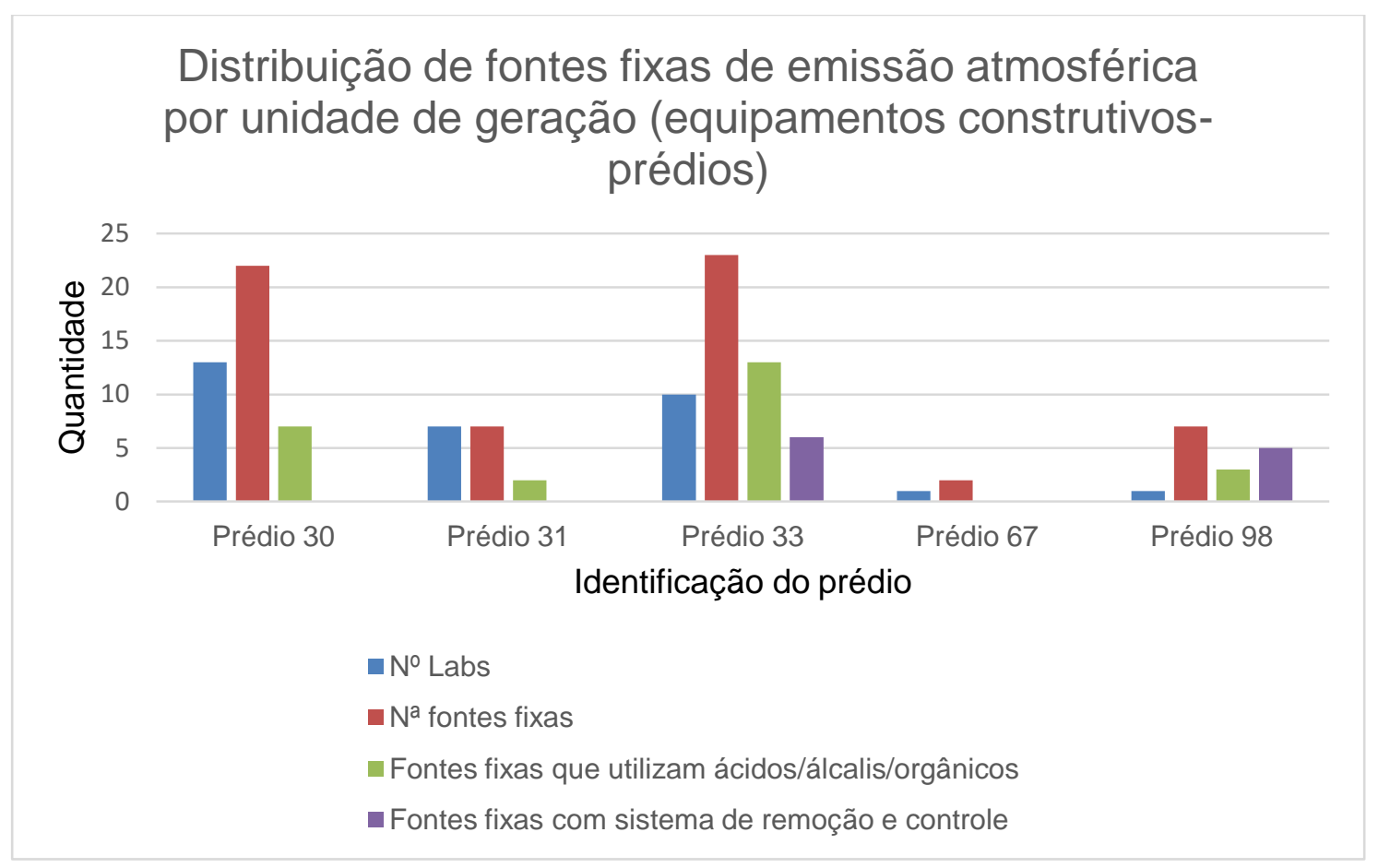


Tabela 11 - Inventário de reagentes consumidos ( $\mathrm{L}$ mês $\left.{ }^{-1}\right)$ nos 09 laboratórios do Centro de Química e Meio Ambiente (Período 2013/2017)

\begin{tabular}{|c|c|c|c|c|}
\hline \multirow{2}{*}{$\begin{array}{c}\text { Identificação por Laboratório } \\
\text { CQMA } \\
\text { LAQA } \\
\text { Análises Química e Ambiental }\end{array}$} & \multicolumn{4}{|c|}{$\begin{array}{l}\text { Inventário de reagentes } \\
\text { Consumo }\left(\text { L. mês }{ }^{-1}\right)\end{array}$} \\
\hline & $2,551,43 \quad 3,44$ & 0,20 & 0,21 & - \\
\hline $\begin{array}{c}\text { LQSA } \\
\text { Química de Solos e Processos de Adsorção }\end{array}$ & $\begin{array}{lll}0,35 & 0,15 & 0,25\end{array}$ & - & - & - \\
\hline $\begin{array}{c}\text { LCP } \\
\text { Síntese e Caracterização de Polímeros }\end{array}$ & - $\quad 1,50$ & - & - & - \\
\hline $\begin{array}{c}\text { LNM } \\
\text { Nanotecnologia Molecular }\end{array}$ & $\begin{array}{lll}1,50 & 0,50 & 0,10\end{array}$ & - & - & - \\
\hline $\begin{array}{l}\text { LQE } \\
\text { Química e Eletroquímica }\end{array}$ & $0,100,20$ & 0,10 & - & - \\
\hline $\begin{array}{c}\text { LPTD } \\
\text { Processos Térmicos de Decomposição de Rejeitos }\end{array}$ & $2,0 \quad 1,0$ & - & $1,0-$ & - \\
\hline $\begin{array}{c}\text { LPMO } \\
\text { Desenvolvimento de Processos de Produção de Mo99 }\end{array}$ & $9^{0,10}$ & - & - & - \\
\hline $\begin{array}{c}\mathrm{LCQ} \\
\text { Caracterização Química }\end{array}$ & $5,414,80 \quad 1,50$ & - & 0,12 & 0,60 \\
\hline $\begin{array}{l}\text { LFX } \\
\text { Fluorescência de Raios X }\end{array}$ & $1,01 \quad 1,01 \quad 0,01$ & - & 0,20 & 0,10 \\
\hline TOTAL & $13,229,096,90$ & 0,30 & 0,53 & 0,70 \\
\hline
\end{tabular}




\subsection{Centro de Biotecnologia}

O Centro de Biotecnologia desenvolve atividades em dois grupos distintos: o de Biofármacos derivados de Toxinas Animais e o de Hormônios Hipofisários, dispondo ainda de um Biotério para criação e manutenção de animais de laboratório.

O centro é composto pelos seguintes laboratórios:

- Laboratório de Biocompatibilidade e Estudos Biológicos in vitro;

- Laboratório de Biologia Molecular/Estrutural;

- Laboratório de Biologia Molecular de Hormônios;

- Laboratório de Biologia Molecular/Angiogenêse;

- Laboratório de Biologia Molecular/Bioquímica;

- Laboratório de Bioquímica de Venenos;

- Laboratório de Bioquímica e Imunologia;

- Laboratório de Biotério de Criação;

- Laboratório de Caracterização Físico-Química de Hormônios;

- Laboratório de Citogenética/Microscopia;

- Laboratório de Cultura Células Animal;

- Laboratório de Cultura de Células - OGM;

- Laboratório de Cultura de Células/Radiobiologia;

- Laboratório de Eletroforese;

- Laboratório de Endopróteses Vasculares;

- Laboratório de Expressão Gênica;

- Laboratório de Farmacologia;

- Laboratório de Fermentação;

- Laboratório de Histologia/Microscopia;

- Laboratório de Liofilização;

- Laboratório de Marcação de Proteínas;

- Laboratório de Nanopolímeros;

- Laboratório de Pressurização de Proteínas; 
- Laboratório de Purificação de Hormônios;

- Laboratório de Purificação de Proteínas;

- Laboratório de Radioensaios;

- Laboratório de Radiotraçadores.

Na Tabela 12 estão apresentados os dados das informações inventariadas dos reagentes químicos utilizados no Centro de Biotecnologia.

Tabela 12 - Inventário por reagentes utilizados no CB

\begin{tabular}{|c|c|c|c|c|c|c|c|c|}
\hline \multirow[b]{2}{*}{$\begin{array}{c}\text { Centro de } \\
\text { Biotecnologia }\end{array}$} & Quantidade de & \multicolumn{7}{|c|}{ Inventário de reagentes (Período 2013/2017) (L. mês ${ }^{-1}$ ) } \\
\hline & \multirow{2}{*}{14} & $\mathrm{HNO}_{3}$ & $\mathrm{HCl}$ & $\mathrm{H}_{2} \mathrm{SO}_{4}$ & $\mathrm{H}_{3} \mathrm{PO}_{4}$ & HF & $\mathrm{H}_{3} \mathrm{ClO}_{4}$ & $\begin{array}{l}\text { Ácido } \\
\text { Acético }\end{array}$ \\
\hline & & & 0,50 & - & 0,30 & - & - & 1,55 \\
\hline
\end{tabular}

Tomando como base as informações do inventário realizado no $\mathrm{CB}$, foram identificados 23 laboratórios que possuem fontes de emissão, de um total de 27 laboratórios. Foram observadas 14 fontes fixas de emissão (Figura 11) Cinco laboratórios utilizam ácidos, álcalis e/ou orgânicos, dois laboratórios que possuem fontes fixas estão fora de uso, totalizando um total de 4 fontes inativas. Foi observado que o CB não possui sistema de controle e/ou remoção de poluentes instalados. 
Figura 11 - Distribuição de fontes fixas no Centro de Biotecnologia

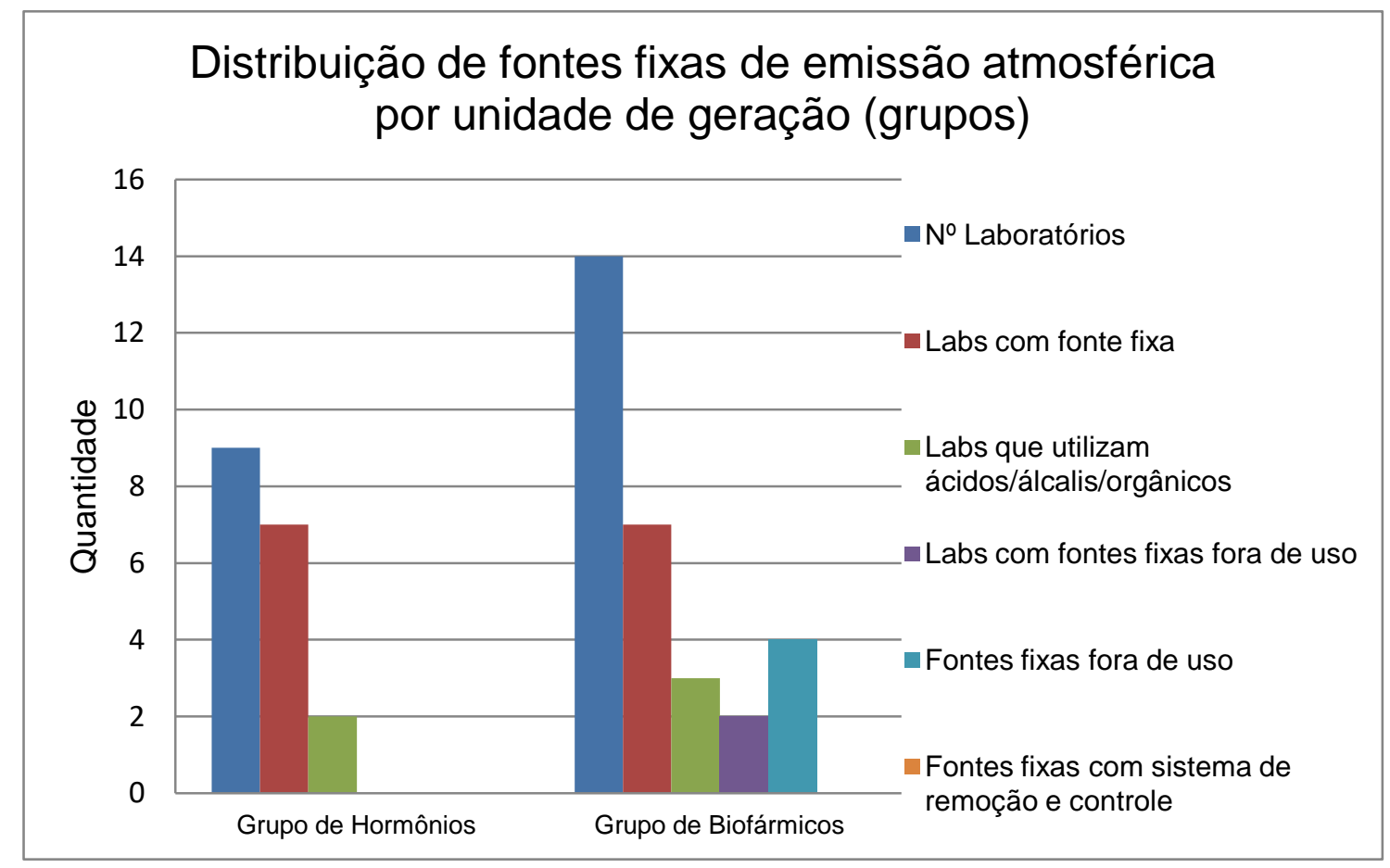




\subsection{Centro de Células a Combustível e Hidrogênio}

Esse centro visa à gestão da pesquisa, desenvolvimento e inovação tecnológica sobre células a combustível objetivando contribuir para o desenvolvimento nacional desta área. $O$ foco principal das pesquisas tem sido o uso de combustíveis, como etanol e gás natural, estratégicos para o país e ambientalmente mais sustentáveis para geração e energia em sistemas de células a combustível. (Disponível em: www.ipen.br).

As operações unitárias envolvidas nos laboratório de catálise e hidrogênio são basicamente: preparação de catalisadores heterogêneos utilizando sais metálicos dos metais de transição. Esta preparação envolve a dissolução desses sais com água e em seguida estes sais são precipitados com solução de hidróxido amônio. A etapa de preparação dos catalisadores ocorre dentro de uma capela de exaustão de gases. A emissão destes gases são pequenas (alguns ppm) e em seguida estes gases produzidos são queimados em flare.

A Tabela 13 mostra um resumo dos resultados obtidos para o total das fontes do inventário do Centro de Células a Combustível e Hidrogênio de acordo com o tipo de poluentes inventariados.

Tabela 13 - Inventário por reagentes utilizados no $\mathrm{CCCH}$

\begin{tabular}{|c|c|c|c|c|c|c|c|c|}
\hline \multirow{3}{*}{$\begin{array}{c}\text { Centro de } \\
\text { Células a } \\
\text { Combustível e } \\
\text { Hidrogênio }\end{array}$} & \multirow{3}{*}{$\begin{array}{c}\text { Quantidade } \\
\text { de Fontes } \\
\text { Fixas }\end{array}$} & \multicolumn{7}{|c|}{ Inventário de reagentes (Período 2013/2017) (L. mês ${ }^{-1}$ ) } \\
\hline & & $\mathrm{HNO}_{3}$ & $\mathrm{HCl}$ & $\mathrm{H}_{2} \mathrm{SO}_{4}$ & $\mathrm{H}_{3} \mathrm{PO}_{4}$ & HF & $\mathrm{H}_{3} \mathrm{ClO}_{4}$ & $\mathrm{NH}_{3} / \mathrm{NH}_{4} \mathrm{OH}$ \\
\hline & & 1.00 & 1.00 & 1.00 & - & - & - & 1.00 \\
\hline
\end{tabular}

O centro possui um laboratório que contém três fontes fixas que utilizam ácidos e álcalis e não há sistema de controle e/ou remoção de poluentes instalados.

\subsection{Centro do Combustível Nuclear}

O Centro do Combustível Nuclear (CCN) é responsável pela produção do combustível nuclear para a operação do reator de pesquisa IEA- 
R1, situado no IPEN. O combustível utilizado nesse reator é do tipo MTR (Materials Testing Reactor), e compreende material físsil (urânio) conformado e metalurgicamente fechado em placas de alumínio. Essas placas compõem o Elemento Combustível (EC), que é o produto rotineiramente fabricado pelo $\mathrm{CCN}$ e entregue ao Centro do Reator de Pesquisa do IPEN.

O centro é dividido nos seguintes laboratórios:

- Unidade de Precipitação de UF

- Laboratório de Recuperação de Urânio;

- Laboratório de Decapagem;

- Laboratório de Tracagem;

- Laboratório de Laminação de placas combustíveis;

- Laboratório de Produção de Urânio Metálico;

- Laboratório de Metalografia.

A Tabela 14 apresenta dados das informações inventariadas referentes às fontes fixas e aos reagentes químicos utilizados/consumidos no Centro de Combustível Nuclear.

Tabela 14 - Inventário por reagentes utilizados no CCN

\begin{tabular}{|c|c|c|c|c|c|c|c|}
\hline \multirow{3}{*}{$\begin{array}{l}\text { Centro do } \\
\text { Combustível } \\
\text { Nuclear }\end{array}$} & \multirow{3}{*}{$\begin{array}{c}\text { Quantidade } \\
\text { de Fontes } \\
\text { Fixas } \\
\\
\mathbf{2 4}\end{array}$} & \multicolumn{6}{|c|}{ Inventário de reagentes (Período 2013/2017) (L. mês ${ }^{-1}$ ) } \\
\hline & & $\mathrm{HNO}_{3}$ & $\mathrm{HCl}$ & $\mathrm{H}_{2} \mathrm{SO}_{4}$ & $\mathrm{H}_{3} \mathrm{PO}_{4}$ & HF & $\mathrm{H}_{3} \mathrm{ClO}_{4}$ \\
\hline & & 7,30 & - & - & - & 3,00 & - \\
\hline
\end{tabular}

O centro possui 18 salas destinadas a laboratórios que contêm 24 fontes fixas ( 5 capelas e 19 coifas), destas, 4 fontes utilizam ácidos, álcalis e/ou orgânicos ( $\mathrm{NaOH}, \mathrm{NH}_{3}$, Ácido Acético, Ácido Etílico e Querosene).

O centro possui instalado em seus processos coifas com sistema de lavador de gases tipo Venturi e um sistema com filtro secundário, sendo realizado controle semestral por análise química de nitrato, pH, fluoreto, estanho e urânio.

A Figura 12 mostra como as fontes fixas estão divididas nos laboratórios do centro. 
Figura 12 - Distribuição de fontes fixas no Centro do Combustível Nucelar

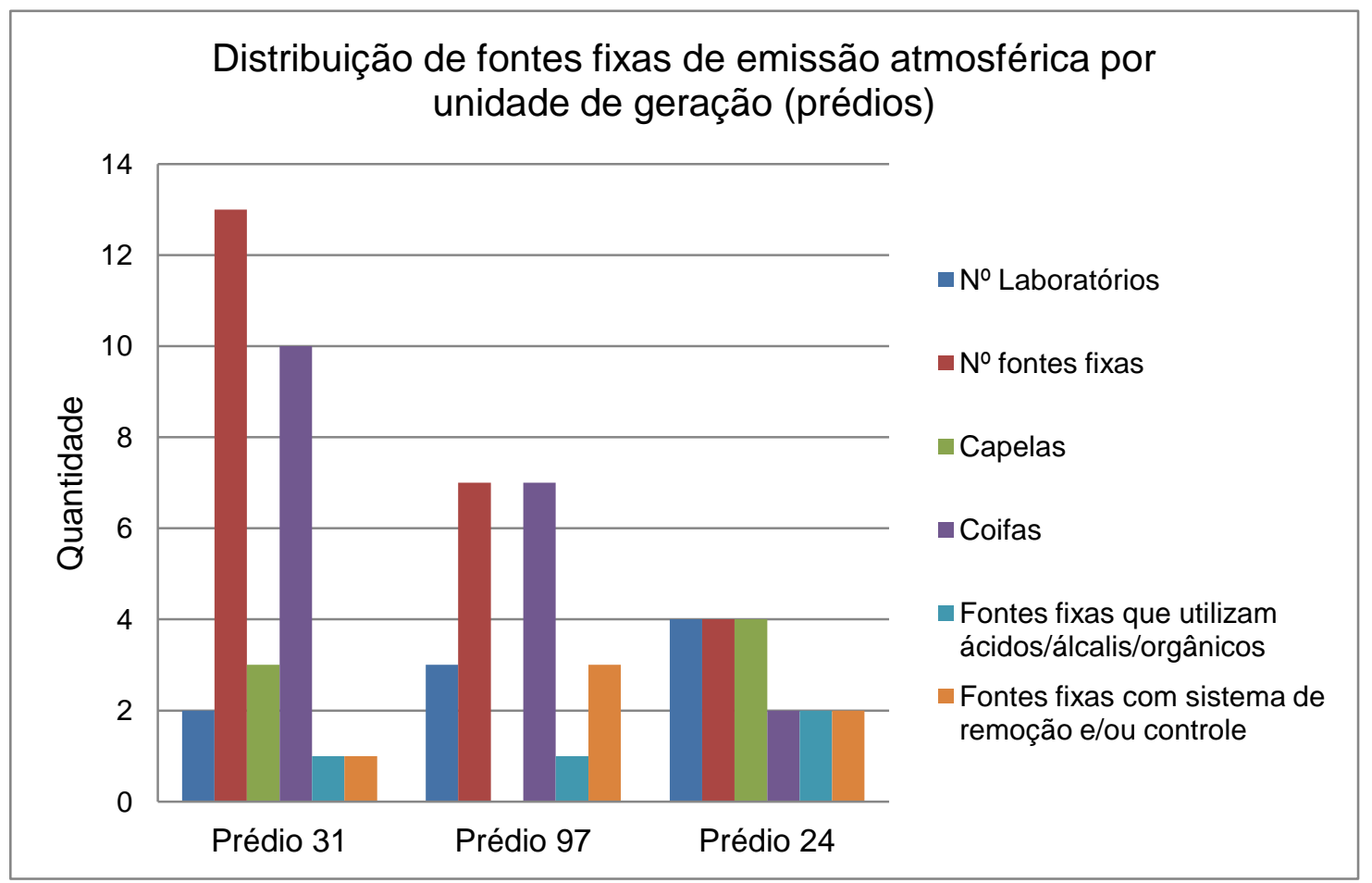

\subsection{Centro de Ciência e Tecnologia dos Materiais}

Atualmente, o centro tem como missão promover a pesquisa e o desenvolvimento nos fundamentos da ciência e engenharia de materiais avançados e convencionais. Suas principais linhas de pesquisas englobam áreas diversas.

O centro é dividido nos seguintes laboratórios:

- Laboratório de Eletroquímica e Revestimentos Protetores;

- Laboratório de Microscopia e Microanálise;

Combustível;

- Laboratório de Cloração e Redução e Células a

- Laboratório de Eletrocerâmicas;

- Laboratório de Processamento de Materiais;

- Laboratório de Insumos;

- Laboratório de Vidros e Compósitos Cerâmicos;

Reologia;

- Laboratório de Processamento Cerâmico de Resíduos e

- Laboratório de Caracterização Física de Materiais;

- Laboratório de Cerâmicas Estruturais e Biomateriais; 
- Laboratório de Fusão;

- Laboratório de Cristalografia Aplicada;

- Laboratório de Materiais Magnéticos;

Mecânico-dinâmica;

- Laboratório de Baterias, Supercapacitadores e Análise

- Laboratório de Biomaterias;

Dinâmicos;

- Laboratório de Modelagem e Caracterização de Processos

- Laboratório de Comportamento Mecânico;

- Laboratório de Metalurgia do Pó e Soldagem;

- Laboratório de Fornos e Conformação para Spray;

- Laboratório de Filmes Finos e Nanoestruturados;

Células Solares;

- Laboratório de Corrosão, Tratamento de Superfícies e

- Laboratório de Difração de Raios X;

- Laboratório de Intermetálicos e Grupos de Avaliação Científica de Materiais.

A Tabela 15 apresenta dados das informações inventariadas dos reagentes químicos utilizados no Centro de Ciência e Tecnologia dos Materiais.

Tabela 15 - Inventário por reagentes utilizados no CCTM

\begin{tabular}{|c|c|c|c|c|c|c|c|}
\hline \multirow{3}{*}{$\begin{array}{c}\text { Centro de } \\
\text { Ciência e } \\
\text { Tecnologia dos } \\
\text { Materiais }\end{array}$} & \multirow{2}{*}{$\begin{array}{c}\text { Quantidade } \\
\text { de Fontes } \\
\text { Fixas } \\
\\
29\end{array}$} & \multicolumn{6}{|c|}{ Inventário de reagentes (Período 2013/2017) (L. mês ${ }^{-1}$ ) } \\
\hline & & $\mathrm{HNO}_{3}$ & $\mathrm{HCl}$ & $\mathrm{H}_{2} \mathrm{SO}_{4}$ & $\mathrm{H}_{3} \mathrm{PO}_{4}$ & HF & $\mathrm{H}_{3} \mathrm{ClO}_{4}$ \\
\hline & 29 & 2,90 & 2,30 & 1,90 & 1,70 & 0,40 & 0,02 \\
\hline
\end{tabular}

O centro possui 23 laboratórios, com um total de 26 salas de laboratório, com 29 fontes fixas, destas, 4 fontes utilizam ácidos, álcalis e/ou orgânicos ( $\mathrm{NaOH}, \mathrm{NH}_{3}$, Ácido Acético, Ácido Etílico e Querosene) e possui sistema de controle de remoção de poluentes no Laboratório de Cloração e Redução e Células a Combustível SOFC.

A Figura 13 mostra como as fontes fixas estão divididas nos laboratórios do centro. 
Figura 13 - Distribuição de fontes fixas no Centro de Tecnologia dos Materiais

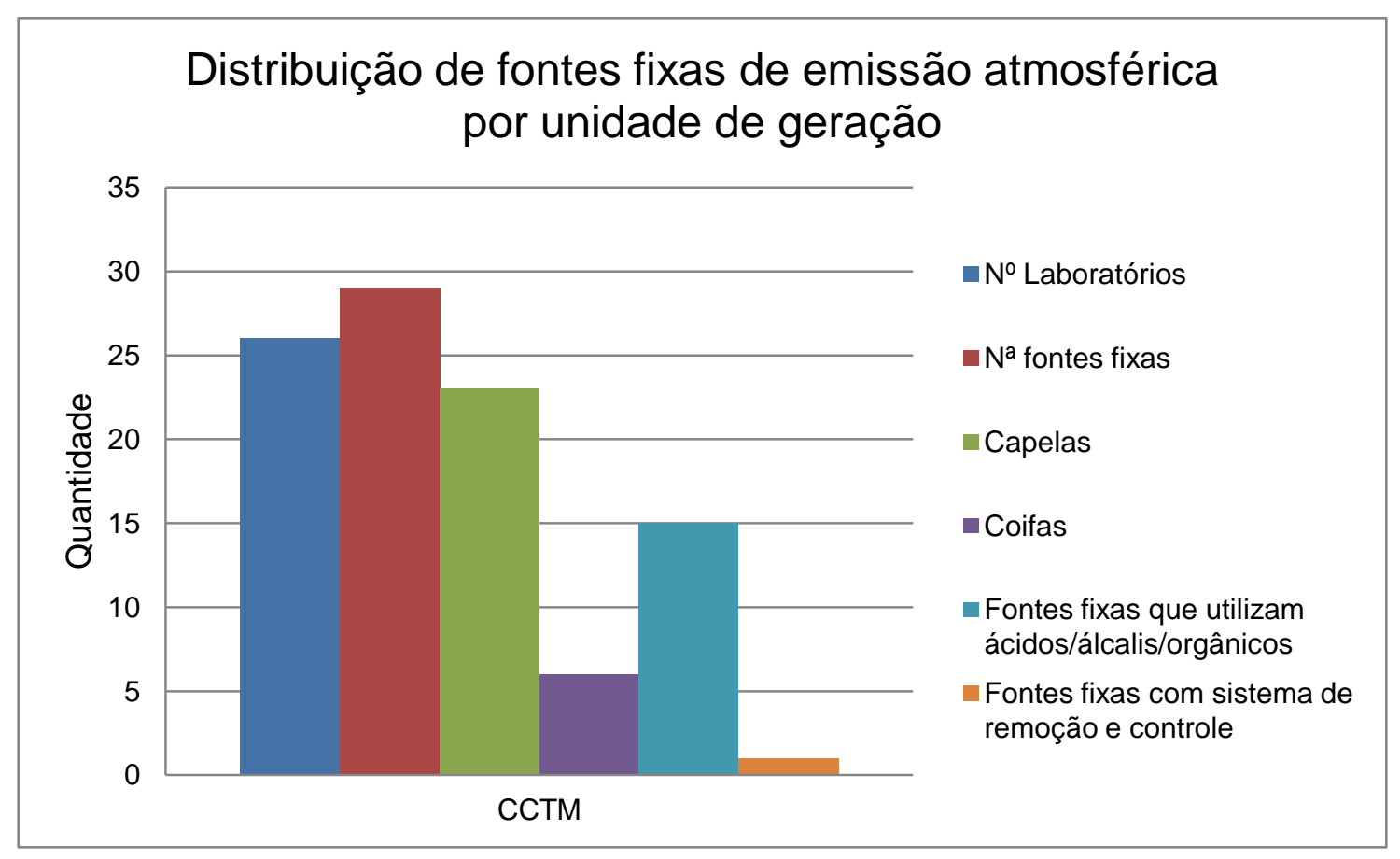

\subsection{Centro de Lasers e Aplicações}

O Centro de Lasers e Aplicações desenvolve competência científica e tecnológica em Lasers de estado sólido, visando a sua aplicação na área de saúde, na área de processamento de materiais, em monitoração ambiental e na área nuclear, formando recursos humanos e gerando produtos e serviços. (Disponível em: www.ipen.br).

O centro está dividido nos seguintes laboratórios:

- Laboratório de Aplicações Ambientais de Lasers;

- Laboratório de Biofotônica;

- Laboratório de Aplicações Nucleares;

- Laboratório de Crescimento de Cristais;

- Laboratório de Desenvolvimento de Lasers;

- Laboratório de Espectroscopia óptica;

- Laboratório de Instrumentação Biomédica;

- Laboratório de Lasers de Altíssima Potência; 
- Laboratório de Microfluídica;

- Laboratório de Polimento de cristais;

- Laboratório de Processamento de Materiais a Laser;

- Laboratório de Processamento de materiais com laser de pulsos ultracurtos;

- Laboratório de Terapia óptica;

- Laboratório de Tomografia de coerência óptica.

A Tabela 16 apresenta os dados das informações inventariadas dos reagentes químicos utilizados nos laboratórios do Centro de Lasers e Aplicações.

Tabela 16 - Inventário por reagentes utilizados no CLA.

\begin{tabular}{|c|c|c|c|c|c|c|c|}
\hline \multirow{3}{*}{$\begin{array}{l}\text { Centro de } \\
\text { Lasers e } \\
\text { Aplicações }\end{array}$} & \multirow{3}{*}{$\begin{array}{c}\text { Quantidade } \\
\text { de Fontes } \\
\text { Fixas } \\
\mathbf{5}\end{array}$} & \multicolumn{6}{|c|}{ Inventário de reagentes e (Período 2013/2017) (L. mês ${ }^{-1}$ ) } \\
\hline & & $\mathrm{HNO}_{3}$ & $\mathrm{HCl}$ & $\mathrm{H}_{2} \mathrm{SO}_{4}$ & $\mathrm{H}_{3} \mathrm{PO}_{4}$ & HF & $\mathrm{H}_{3} \mathrm{ClO}_{4}$ \\
\hline & & - & - & $<0,5^{\star}$ & $<0,5^{*}$ & - & - \\
\hline
\end{tabular}

${ }^{*} \mathrm{O}$ uso desses reagentes é eventual.

O centro possui um total de 14 laboratórios, sendo que dois (2) possuem fontes fixas (5), destas, uma fonte utiliza ácidos e há sistemas de controle e/ou remoção de poluentes instalados.

A Figura 14 mostra como as fontes fixas estão divididas nos laboratórios do centro. 
Figura 14 - Distribuição de fontes fixas no Centro de Lasers e Aplicações.

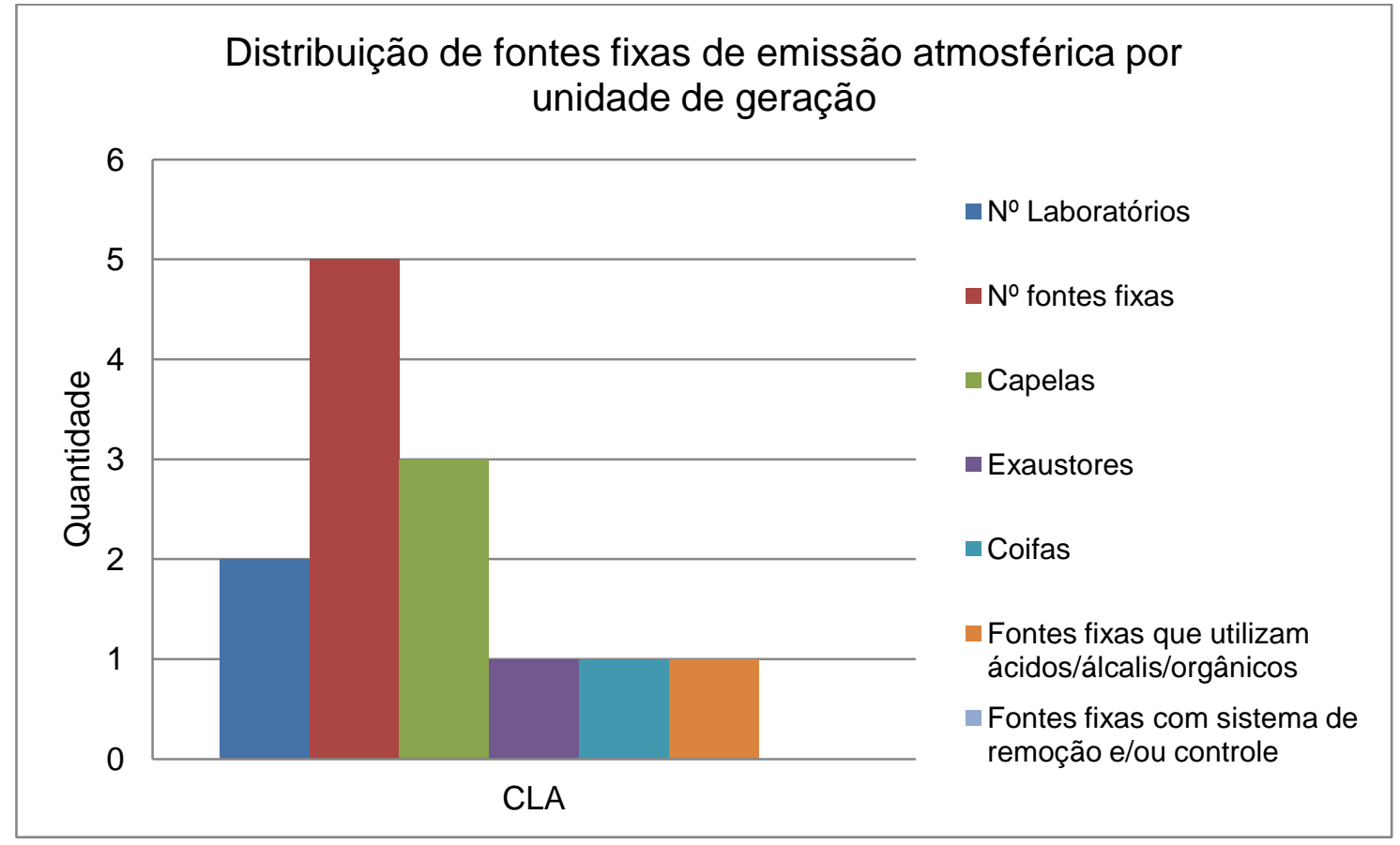

\subsection{Centro de Radiofarmácia}

O centro tem como objetivo produzir radiofármacos para diagnóstico e terapia em Medicina Nuclear. Atende mais de 250 hospitais no país.

O centro é dividido da seguinte forma:

- Equipe de Radioproteção;

- Gerência de Aceleradores Cíclotrons;

- Gerência de Controle da Qualidade;

- Gerência de Garantia da Qualidade;

- Gerência de Infraestrutura e Apoio;

- Gerência de Pesquisa e Desenvolvimento;

- Gerência de Produção.

As operações envolvidas nos laboratórios de Controle de Qualidade são basicamente: diluição/reconstituição da amostra (com água purificada ou $\mathrm{NaCl}$ 0,9\%) e análise por cromatografia em papel ou camada delgada. A diluição das amostras e a preparação/mistura de soluções/solventes para a cromatografia ocorrem em capela de exaustão. As cromatografias do Lab. AS-20 são realizadas em capela de exaustão. Todos 
os reagentes são utilizados em quantidades pequenas por processo de controle de qualidade. Não existem processos de evaporação.

A Tabela 17 apresenta os dados das informações inventariadas dos reagentes químicos utilizados no Centro de Radiofarmácia. 
Tabela 17 - Inventário por reagentes utilizados no CR.

\begin{tabular}{|c|c|c|c|c|c|c|c|c|c|c|c|c|c|c|}
\hline \multirow{2}{*}{$\begin{array}{l}\text { Centro de } \\
\text { Radiofarmácia }\end{array}$} & \multirow{2}{*}{$\begin{array}{l}\text { Quantidade de } \\
\text { Fontes Fixas }\end{array}$} & \multicolumn{13}{|c|}{ Inventário de reagentes e Estimativa da Taxa de atividade (Período 2013/2017) (L. mês ${ }^{-1}$ ) } \\
\hline & & $\mathrm{HNO}_{3}$ & $\mathrm{HCl}$ & $\mathrm{C}_{3} \mathrm{H}_{6} \mathrm{O}$ & $\mathrm{CH}_{3} \mathrm{OH}$ & $\mathrm{C}_{2} \mathrm{H}_{3} \mathrm{~N}$ & $\mathrm{C}_{4} \mathrm{H}_{8} \mathrm{O}$ & $\mathrm{CH}_{3} \mathrm{COOH}$ & $\mathrm{C}_{2} \mathrm{H}_{6} \mathrm{O}$ & $\mathrm{C}_{4} \mathrm{H}_{8} \mathrm{O}_{2}$ & $\mathrm{CHCl}_{3}$ & $\left(\mathrm{C}_{2} \mathrm{H}_{5}\right)_{2} \mathrm{O}$ & $\begin{array}{l}\text { Eter de } \\
\text { Petróleo }\end{array}$ & $\mathrm{C}_{4} \mathrm{H}_{10} \mathrm{O}$ \\
\hline & & 0,02 & 0,05 & 0,55 & 0,2 & 0,15 & 0,01 & 0,12 & 0,11 & 0,03 & 0,05 & 0,04 & 0,02 & 0,05 \\
\hline
\end{tabular}

$\mathrm{C}_{3} \mathrm{H}_{6} \mathrm{O}$ - Acetona; $\mathrm{CH}_{3} \mathrm{OH}$ - Metanol; $\mathrm{C}_{2} \mathrm{H}_{3} \mathrm{~N}$ - Acetonitrila; $\mathrm{C}_{4} \mathrm{H}_{8} \mathrm{O}$ - Tetraidrofurano; $\mathrm{CH}_{3} \mathrm{COOH}$ - Ácido Acético; $\mathrm{C}_{2} \mathrm{H}_{6} \mathrm{O}-$ Etanol; $\mathrm{C}_{4} \mathrm{H}_{8} \mathrm{O}_{2}$ - Acetato de Etila; $\mathrm{CHCl}_{3}-$ Clorofórmio; $\left(\mathrm{C}_{2} \mathrm{H}_{5}\right)_{2} \mathrm{O}$ - Éter Etílico; $\mathrm{C}_{4} \mathrm{H}_{10} \mathrm{O}$ - Butanol-1.

O centro possui 3 laboratórios que contêm fontes fixas (11), destas, todas as fontes utilizam ácidos/orgânicos e álcalis possuem em suas capelas de exaustão / glove box sistemas com filtros HEPA específicos. Detectores de radiação estão disponíveis e operacionais para controle ambiental.

A Figura 15 mostra como as fontes fixas estão divididas nos laboratórios do centro. 
Figura 15 - Distribuição de fontes fixas no Centro de Radiofarmácia

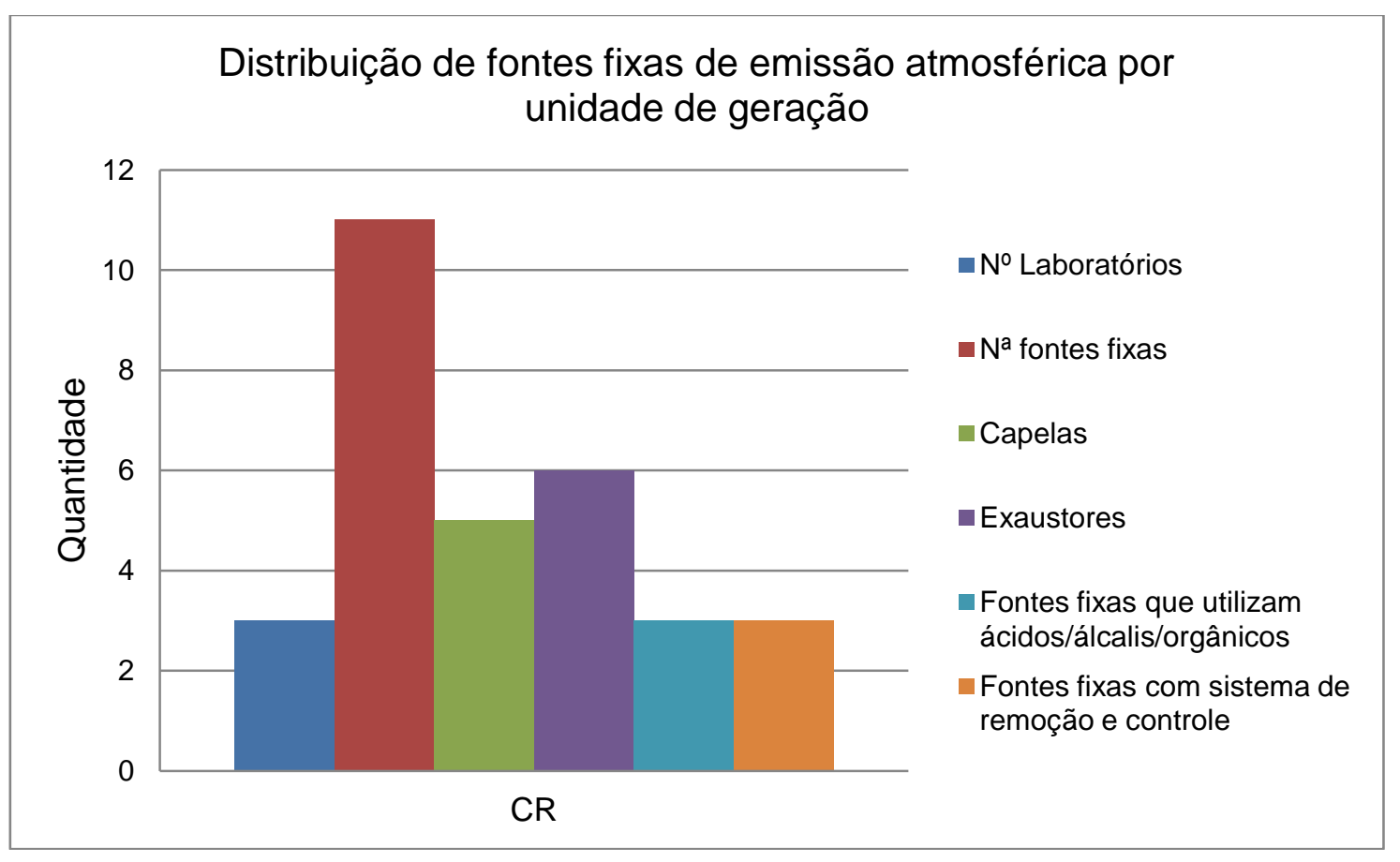

\subsection{Centro de Tecnologia das Radiações}

O centro tem como missão aplicar a tecnologia das radiações e dos radioisótopos na Saúde, Indústria e Meio Ambiente (Disponível: www.ipen.br).

As atividades de P\&D utilizando a tecnologia das radiações e radioisótopos estão voltadas aos clientes, dos mais diversos seguimentos: indústrias químicas, petroquímicas, de embalagens, farmacêuticas, automobilísticas, alimentícias, agrícola, mecânica pesada, saneamento básico, além das universidades, instituições de pesquisa, clínicas e hospitais. O CTR dá suporte à comunidade, através da utilização de radiação e radioisótopos em diversas aplicações:

- Processamento por radiação utilizando os aceleradores industriais de elétrons e irradiadores gama, nas seguintes atividades: Desenvolvimento de novos processos e produtos; Produção e modificações de polímeros, compósitos, nanocompósitos, nanotecnologia, polímeros naturais e nanocompósitos a base de grafeno por processamento por radiação; Desenvolvimento de embalagens processadas por radiação para alimentos; Radioesterilização de produtos médicos e farmacêuticos; Radioesterilização para banco de tecidos biológicos; 
Desinfestação e preservação de alimentos e produtos agrícolas; Beneficiamento de pedras preciosas; Desinfestação e preservação de bens culturais; e Tratamento de efluentes industriais e lixo hospitalar.

- Desenvolvimento de irradiadores, equipamentos nucleares e aplicações de radioisótopos na indústria: Desenvolvimento de detectores e sensores de radiação; Desenvolvimento de tomografia para processos industriais; Desenvolvimento de dispositivos de irradiação; Dosimetria industrial; Desenvolvimento de tecnologia de radioisótopos para controle de processos multifásicos industriais (sistemas dinâmicos e estáticos); e Aplicação de radiotraçadores na hidrologia e no controle de processos industriais.

- Desenvolvimento e produção de fontes seladas para Saúde e Indústria: Desenvolvimento e distribuição de sementes de ${ }^{125}$ utilizado na Braquiterapia, para tratamento de câncer; Desenvolvimento de fios de ${ }^{192}$ Ir para tratamento de câncer; Produção de fontes de referência para calibração ou aferição de curiômetros usuais da medicina nuclear; e Produção de fontes radioativas seladas de ${ }^{192} \mathrm{Ir}$ e ${ }^{60} \mathrm{Co}$ para gamagrafia industrial. (Disponível em: www.ipen.br)

O centro é dividido pelos seguintes laboratórios:

- Laboratório Químico Orgânico;

- Laboratório Químico Instrumental;

- Laboratório Cura por Radiação;

- Laboratório de Preparação de Traçadores;

- Laboratório de Detectores semicondutores;

- Laboratório de Detectores semicondutores;

- Laboratório de Crescimento de Cristais;

- Laboratório de Tratamento de Superfícies;

- Laboratório de Modificação de materiais por radiação ionizante;

- Laboratório de Desenvolvimento de embalagens poliméricas;

- Laboratório de Preparação de amostras para irradiação;

- Laboratório de Preparo de Amostras para a Irradiação;

- Laboratório de Produção de Fontes para Radioterapia. 
A Tabela 18 apresenta os dados das informações inventariadas dos reagentes químicos utilizados no Centro de Tecnologia das Radiações.

Tabela 18 - Inventário por reagentes utilizados no CTR

\begin{tabular}{|c|c|c|c|c|c|c|c|c|c|c|}
\hline \multirow{3}{*}{$\begin{array}{l}\text { Centro de } \\
\text { Tecnologia das } \\
\text { Radiações }\end{array}$} & $\begin{array}{l}\text { Quantidade de } \\
\text { Fontes Fixas }\end{array}$ & \multicolumn{9}{|c|}{ Inventário de reagentes (Período 2013/2017) (L. mês ${ }^{-1}$ ) } \\
\hline & & $\mathrm{HNO}_{3}$ & $\mathrm{HCl}$ & $\mathrm{H}_{2} \mathrm{SO}_{4}$ & $\mathrm{H}_{3} \mathrm{PO}_{4}$ & HF & $\begin{array}{c}\mathrm{NH}_{3} / \\
\mathrm{NH}_{4} \mathrm{OH}\end{array}$ & $\mathrm{C}_{3} \mathrm{H}_{6} \mathrm{O}$ & $\mathrm{C}_{2} \mathrm{H}_{3} \mathrm{~N}$ & $\mathrm{C}_{8} \mathrm{H}_{7}$ \\
\hline & & 1,05 & 0,25 & 0,05 & 0,05 & 0,50 & 0,11 & 0,10 & 0,10 & 0,10 \\
\hline
\end{tabular}

$\mathrm{C}_{3} \mathrm{H}_{6} \mathrm{O}-$ Acetona; $\mathrm{C}_{2} \mathrm{H}_{3} \mathrm{~N}-$ Acetonitrila; $\mathrm{C}_{8} \mathrm{H}_{7}-$ Estireno.

O centro possui 15 laboratórios que contêm fontes fixas (12), destas, três fontes utilizam ácidos/orgânicos e álcalis. $O$ Laboratório de Produção de Fontes para Radioterapia: possui uma capela de exaustão na qual está ligado um sistema HEPA filtro com carvão ativo, sistema esse monitorado por detecção.

A Figura 16 mostra como as fontes fixas estão divididas nos laboratórios do centro. 
Figura 16 - Distribuição de fontes fixas no Centro de Tecnologia das Radiações.

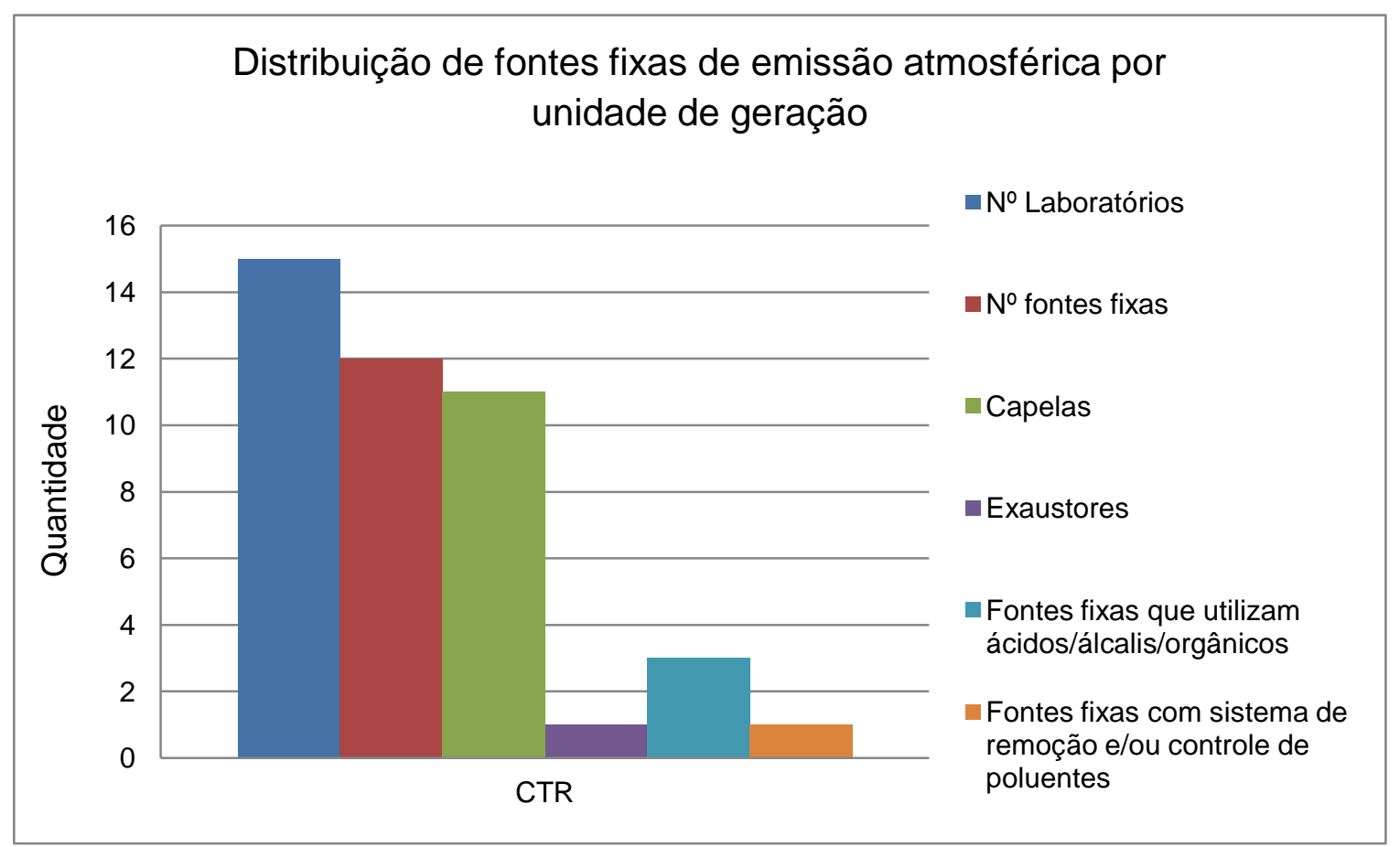


No Laboratório de preparação de traçadores, a estimativa mensal de manipulação de metal mercúrio ( 0,6 litro/mês), cujo material é totalmente devolvido para o contratante após a conclusão do serviço.

Há dois Irradiadores no centro onde possuem dois sistemas de exaustão independentes (um para o irradiador de cobalto multipropósito e um para os dois aceleradores de elétrons). Há geração de ozônio durante a irradiação (a 01 metro de distância das saídas das respectivas chaminés). A concentração limite de emissão do gás ozônio no ar é de 0,08 ppm ou 0,16 $\mathrm{mg} / \mathrm{m}^{3}$ (CONAMA, 1990).

\subsection{Gerência de Rejeitos Radioativos}

Tem como objetivo promover a gestão segura dos rejeitos radioativos gerados em todo o Brasil a fim de proteger o homem e o meio ambiente.

É responsável pelo recebimento, tratamento e armazenamento dos rejeitos radioativos gerados nas aplicações nucleares no Estado de São Paulo e região sul do Brasil, o que representa, aproximadamente, $80 \%$ dos rejeitos institucionais gerados no país. Além desses, dependendo de alguns fatores, recebe também rejeitos de outros Estados brasileiros. (Disponível em: www.ipen.br).

A Tabela 19 apresenta os dados das informações inventariadas dos reagentes químicos utilizados na Gerência de Rejeitos Radioativos.

Tabela 19 - Inventário por reagentes utilizados na GRR.

\begin{tabular}{cccccc} 
& \multicolumn{3}{c}{$\begin{array}{c}\text { Quantidade de Fontes } \\
\text { Fixas }\end{array}$} & \multicolumn{4}{c}{$\begin{array}{c}\text { Inventário de reagentes (Período } \\
\left.\text { 2013/2017) (L. mês }{ }^{-1}\right)\end{array}$} \\
\cline { 2 - 6 } $\begin{array}{c}\text { Gerência de Rejeitos } \\
\text { Radioativos }\end{array}$ & 6 & $\mathbf{H N O}_{3}$ & $\mathbf{H C l}$ & $\mathbf{H}_{2} \mathbf{S O}_{4}$ & HF \\
\cline { 2 - 7 } & 6 & 2,60 & 1,30 & 3,00 & 0,10
\end{tabular}

Os laboratórios da unidade possuem medidas preventivas e de controle para impedir a geração de poluentes atmosféricos quando se trata de manipulação de material nuclear e rejeitos radioativos, sendo: dois sistemas de remoção de filtros HEPA para particulado e um sistema misto de filtros de HEPA e carvão ativado, sendo que todas possuem um sistema de 
monitoramento com detector portátil de radiação.

A Figura 17 mostra como as fontes fixas estão divididas nos laboratórios do centro.

Figura 17 - Distribuição de fontes fixas na Gerência de Rejeitos Radioativos

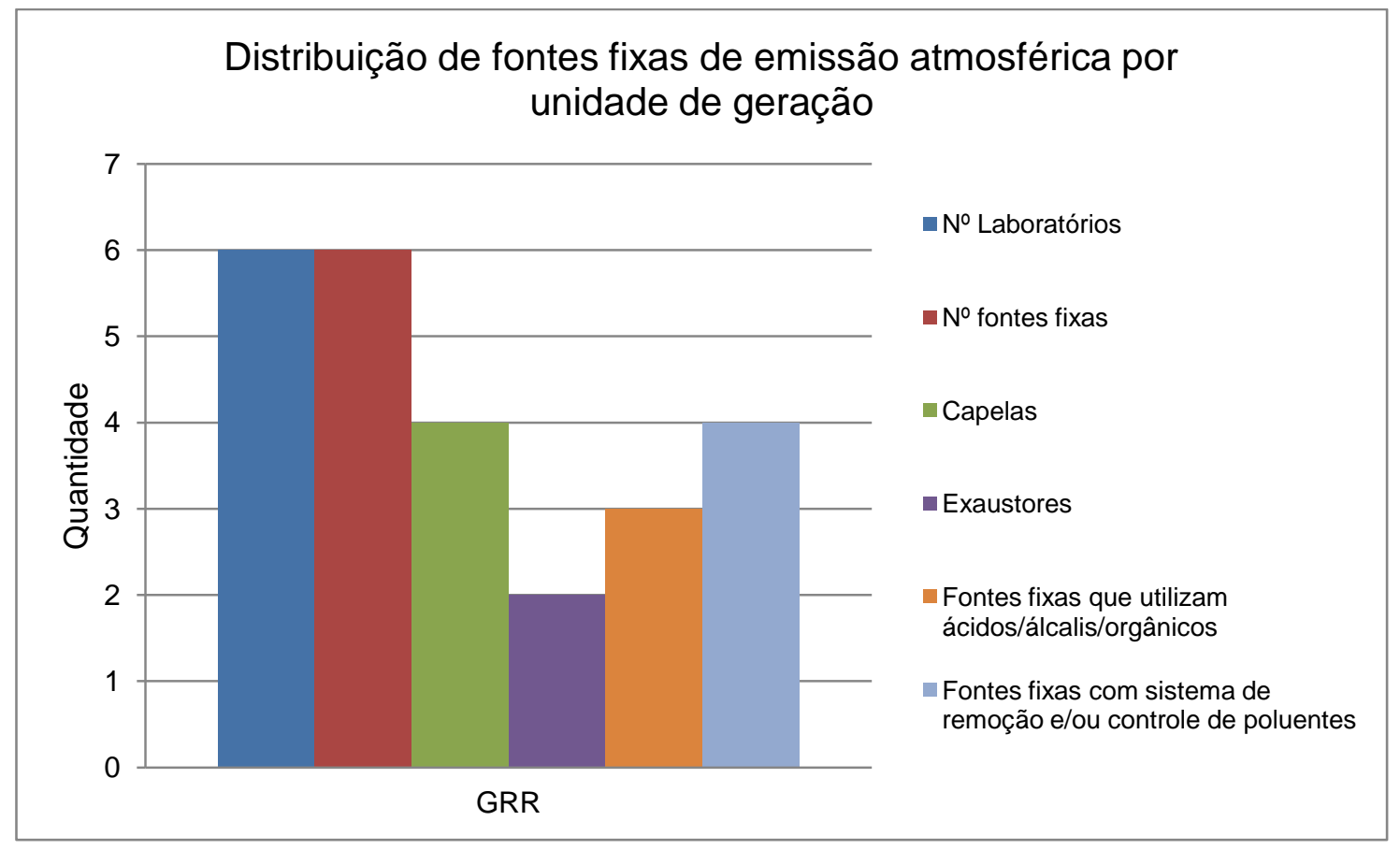

\subsection{Gerência de Metrologia das Radiações}

A gerência é responsável pelo desenvolvimento de sistemas de referência para radiações $X$, gama, alfa, beta e de nêutrons.

Os processos realizados nos laboratórios da gerência são pouco significativos em relação a emissões de poluentes atmosféricos, conforme dados apresentados. As principais características de segurança apresentadas nos laboratórios são as blindagens estruturais fixas e móveis e as celas, caixas com luvas e capelas com exaustão. Basicamente, as características de segurança estão correlacionadas principalmente com os desvios de procedimentos, sendo que em condições normais de operação a instalação é segura. Uso de blindagens estruturais fixas e móveis e capelas com exaustão. São manuseadas pequenas quantidades de materiais radioativos e/ou produtos perigosos.

A Tabela 20 apresenta os dados das informações inventariadas dos 
reagentes químicos utilizados na Gerência de Metrologia das Radiações.

Tabela 20 - Inventário por reagentes utilizados na GRR.

\begin{tabular}{cccccc} 
Gerência de & $\begin{array}{c}\text { Quantidade de } \\
\text { Fontes Fixas }\end{array}$ & \multicolumn{2}{c}{$\begin{array}{c}\text { Inventário de reagentes e Estimativa da Taxa de } \\
\text { atividade (Período 2013/2015/2017) }\left(\text { L. mês }{ }^{-1} \text { ) }\right.\end{array}$} \\
\cline { 2 - 6 } $\begin{array}{c}\text { Metrologia das } \\
\text { Radiações }\end{array}$ & $\mathbf{1 8}$ & $\mathbf{H N O}_{3}$ & $\mathbf{H C l}$ & $\mathbf{H}_{2} \mathbf{S O}_{4}$ & $\mathbf{H F}$ \\
\cline { 2 - 6 } & & 9 & 14 & 6 & 4
\end{tabular}

A gerência possui 18 fontes fixas de poluição, sendo que 5 estão fora de uso. Não há sistema de controle e/ou remoção de poluentes instalados.

A Figura 18 mostra como as fontes fixas estão divididas nos laboratórios do centro.

Figura 18 - Distribuição de fontes fixas na Gerência de Metrologia das Radiações.

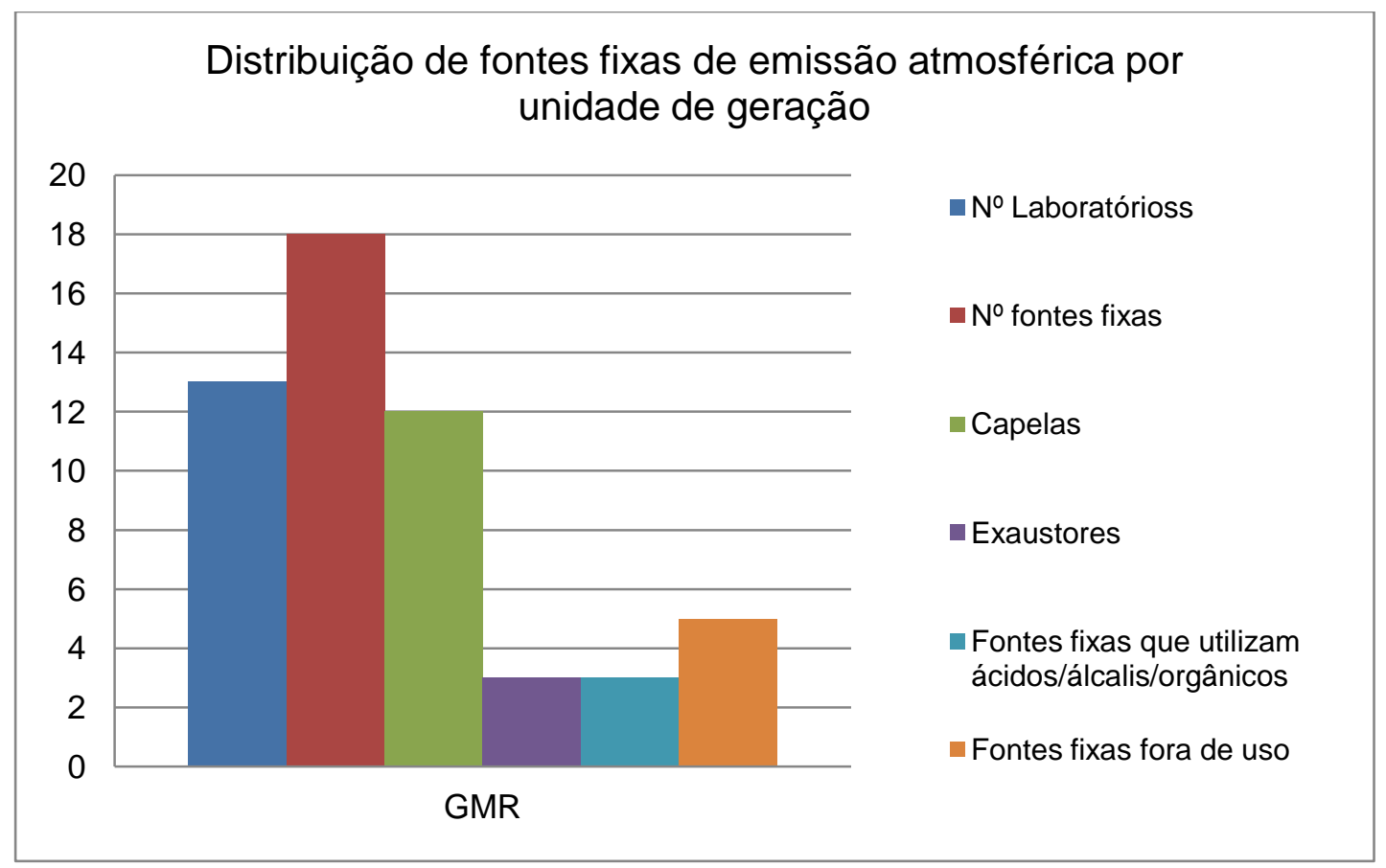




\section{CÁlCULO DAS TAXAS DE EMISSÕES}

Foi adotada a equação simplificada descrita na AP-42 (EPA,1995). A equação utilizada é a combinação das informações sobre as atividades, levantamento dos reagentes utilizados nas fontes fixas, com os fatores de emissão, que relaciona a quantidade de poluentes emitidos por atividades. Como resultado, temos a taxa de emissão que relaciona a quantidade de emissão de determinado poluente por tempo (Taxa de Emissão = Taxa de Atividade $x$ Fator de emissão).

Os cálculos foram adotados em unidade de massa, para isto, utilizouse a propriedade físico-química, densidade de cada reagente para transformar a taxa da atividade de [L. mês $\left.{ }^{-1}\right]$ para [g. mês $\left.{ }^{-1}\right]$. A Tabela 21 apresenta os ácidos e suas respectivas densidades foram:

Tabela 21 - Descrição e densidade dos reagentes inventariados.

\begin{tabular}{ccc} 
Reagente & CAS & $\begin{array}{c}\text { Densidade } \\
{\left[\mathrm{g} \cdot\left(\mathrm{cm}^{3}\right)^{-1} \mathrm{a} 20^{\circ} \mathrm{C}\right]}\end{array}$ \\
& Ácido Nítrico, \\
65\% PA & $7697-37-2$ & 1,39 \\
\hline $\begin{array}{c}\text { Ácido Clorídrico, } \\
\text { 37\% PA }\end{array}$ & $7647-01-0$ & 1,19 \\
\hline $\begin{array}{c}\text { Ácido Sulfúrico, } \\
\text { 95 - 97\% PA }\end{array}$ & $7664-93-9$ & 1,84 \\
\hline $\begin{array}{c}\text { Ácido Fluorídrico, } \\
\text { 48\% PA }\end{array}$ & $7664-34-3$ & 1,16
\end{tabular}

Fonte: Adaptado Merck.

Os fatores de emissão adotados neste estudo, utilizando como modelo a EPA (AP-42) (Apêndice A), foram também os mais críticos, levando em conta processos produtivos, e se referem à unidade de massa [lb.ton de ácido produzido $^{-1}$ ], sendo necessário adotar a transformação em [kg.kg de ácido utilizado $^{-1}$ ]; (1 lb equivale a $\left.0,45 \mathrm{~kg}\right)$.

Os fatores de emissão utilizados estão apresentados na Tabela 22. 
Tabela 22 - Fatores de emissão descritos na AP-42

IDENTIFICAÇÃO DO REAGENTE

FATOR DE EMISSÃO

[lb.ton de ácido produzido ${ }^{-1}$ ]

\begin{tabular}{cc}
\hline $\mathrm{HNO}_{3}$ & 57 \\
\hline $\mathrm{HCl}$ & 1,8 \\
\hline $\mathrm{H}_{2} \mathrm{SO}_{4}$ & 70 \\
\hline $\mathrm{HF}$ & 25
\end{tabular}

Fonte: Adaptado AP - 42.

Para o ácido perclórico $\left(\mathrm{H}_{3} \mathrm{ClO}_{4}\right)$ e para o ácido fosfórico $\left(\mathrm{H}_{3} \mathrm{PO}_{4}\right)$ não há fator de emissão disponível na AP - 42.

Para calcular as estimativas de emissões atmosféricas de $\mathrm{NO}_{\mathrm{x}}, \mathrm{SO}_{\mathrm{x}}$, $\mathrm{Cl}^{-}$e $\mathrm{F}^{-}$tomou-se como base estes dados. A Tabela 23 apresenta a taxa de emissão mensal dos laboratórios do Centro de Química e Meio Ambiente.

Tabela 23 - Taxa de Emissão dos poluentes emitidos nos laboratórios do CQMA.

IDENTIFICAÇÃO DO LABORATÓRIO
TAXA DE EMISSÃO MENSAL [kg.kg de ácido utilizado ${ }^{-1}$ ]

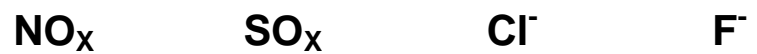

\begin{tabular}{ccccc} 
LAQA & 0,0909 & 0,1994 & 0,0014 & 0,0027 \\
\hline LQSA & 0,0125 & 0,0148 & 0,0001 & - \\
\hline LCP & 0,0071 & 0,0869 & - & - \\
\hline LNM & 0,0535 & 0,0058 & 0,0005 & - \\
\hline LQE & 0,0036 & - & 0,0002 & - \\
\hline LPTD & 0,0713 & - & 0,0010 & 0,0127 \\
\hline LPMO & 0,0036 & 0,0058 & - & - \\
\hline LCQ & 0,1929 & $0,0869-$ & 0,0046 & 0,0015 \\
\hline LFRX & 0,0360 & 0,0006 & 0,0010 & 0,0025
\end{tabular}

O Laboratório de Cromatografia de Íons e o de Lavagem de Material (pertencentes ao LAQA), apesar de apresentarem elevado consumo de reagentes, não foram introduzidos nos cálculos de emissão atmosférica, pois são gerenciados dentro do programa de gestão de resíduos químicos do IPEN.

A Tabela 24 apresenta um resumo das taxas de emissão mensal calculadas, considerando os diferentes poluentes para cada por cada centro de 
pesquisa do Ipen.

Tabela 24 - Taxa de Emissão dos poluentes emitidos nos laboratórios dos centros de pesquisa do IPEN.

IDENTIFICAÇÃO DO CENTRO

TAXA DE EMISSÃO MENSAL [kg.kg de ácido utilizado ${ }^{-1}$ ]

\begin{tabular}{ccccc} 
& NOx $_{\mathbf{x}}$ & SO $_{\mathbf{x}}$ & $\mathbf{C l}^{-}$ & $\mathbf{F}^{-}$ \\
\cline { 2 - 5 } CQMA & 0,4713 & 0,3133 & 0,0088 & 0,0195 \\
\hline CB & - & - & 0,0005 & - \\
\hline CCCH & 0,0359 & 0,0584 & 0,0010 & - \\
\hline CCN & 0,2623 & - & - & - \\
\hline CCTM & 0,1042 & 0110 & 0,0022 & 0,0053 \\
\hline CLA & - & 0,0292 & - & - \\
\hline CR & 0,0007 & 0,0058 & - & - \\
\hline CTR & 0,0377 & 0,0029 & 0,0002 & 0,0066 \\
\hline GRR & 0,0934 & 0,1753 & 0,0013 & 0,0013 \\
\hline GMR & 0,3234 & 0,3505 & 0,0136 & 0,0526
\end{tabular}

\subsection{Comparação dos valores com Normas e Padrões Estabelecidos}

Após a realização dos cálculos para estimar a taxa de emissão mensal de cada centro de pesquisa, a fim de comparar com as normas e padrões estabelecidos que estão em $\mu \mathrm{g} \cdot \mathrm{m}^{3}$, houve a necessidade de transformar as unidades. Para isto foram utilizados o período trabalhado e a vazão. A Tabela 25 traz a concentração de $\mathrm{NO}_{x}$ e $\mathrm{SO}_{x}$ por unidade geradora de poluentes atmosféricos (centros). 
Tabela 25 - Concentração de $\mathrm{NO}_{x}$ e $\mathrm{SO}_{x}$ por centro de pesquisa do IPEN

\begin{tabular}{ccc} 
CONCENTRAÇÃO $\left[\mu \mathrm{g} / \mathrm{m}^{3}\right]$ & $\begin{array}{c}\mathrm{NO} \\
{[\mu \mathrm{g} / \mathrm{m} 3]}\end{array}$ & $\begin{array}{c}\mathrm{SO}_{\mathrm{x}} \\
{\left[\mu \mathrm{g} / \mathrm{m}^{3}\right]}\end{array}$ \\
\hline CQMA & 0,29694 & 0,0082 \\
\hline CB & - & - \\
\hline CCCH & 0,2246 & 0,0019 \\
\hline CCN & 1,6397 & - \\
\hline CCTM & 0,6514 & 0,0036 \\
\hline CLA & - & 0,0010 \\
\hline CR & - & - \\
\hline CTR & 0,2358 & 0,0001 \\
\hline GRR & 0,5840 & 0,0058 \\
\hline GMR & 2,0215 & 0,0115
\end{tabular}

As Figuras 19 e 20 trazem a comparação das concentrações de $\mathrm{NO}_{x} \mathrm{e}$ $\mathrm{SO}_{\mathrm{x}}$ calculadas dos centros de pesquisa com as Legislações no âmbito federal, CONAMA no 03/1990 e estadual, Decreto 59.113/2013.

Figura 19 - Valores médios de $\mathrm{NO}_{x}$ por hora determinados a partir da taxa de emissão atmosféricas das fontes fixas pertencentes aos Laboratórios dos Centros do Ipen comparação com legislação ambiental federal e estadual.

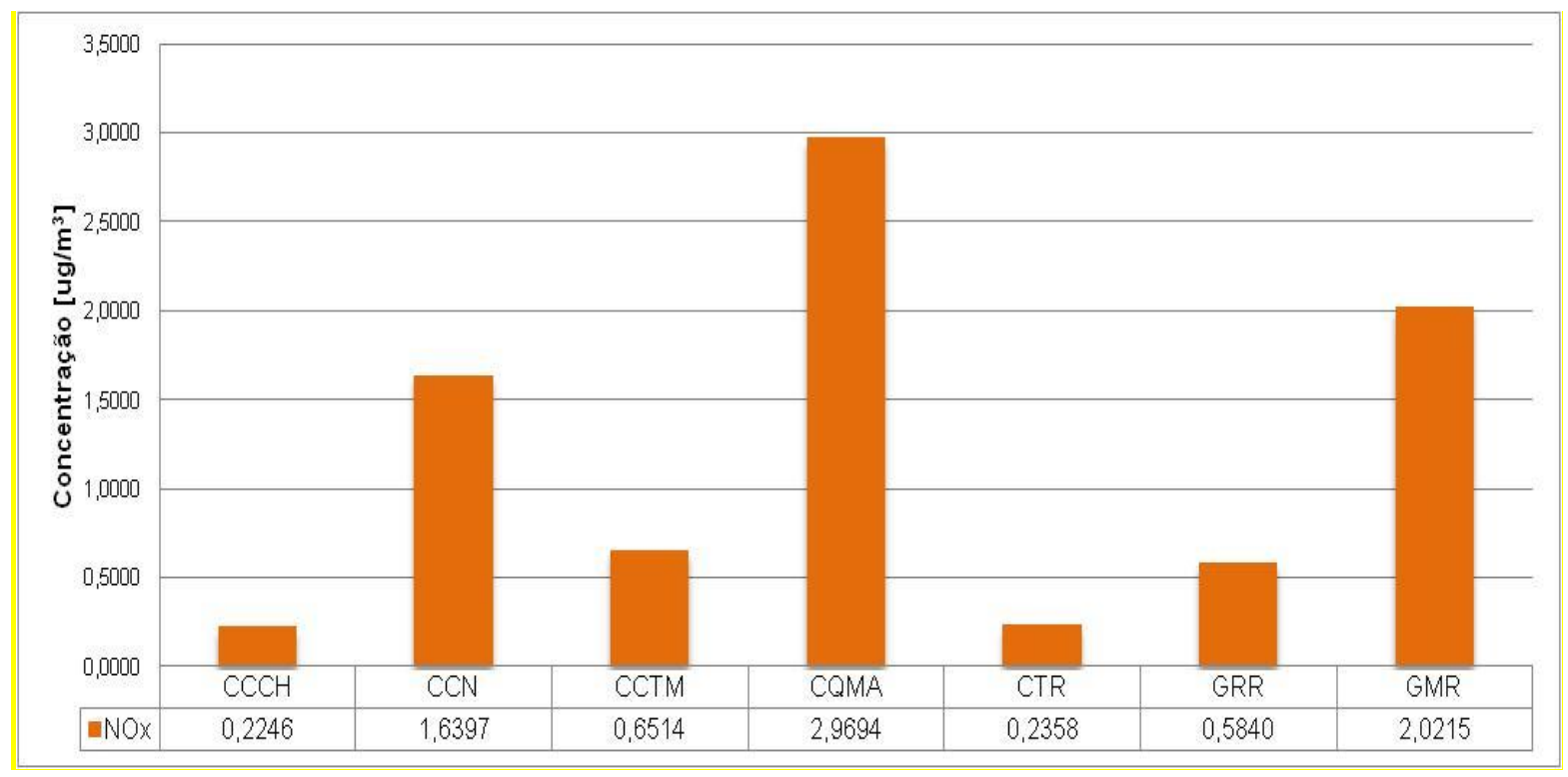


Figura 20: Valores médios de SOx por hora determinados a partir da taxa de emissão atmosféricas das fontes fixas pertencentes aos Laboratórios dos Centros do Ipen comparação com legislação ambiental federal e estadual.

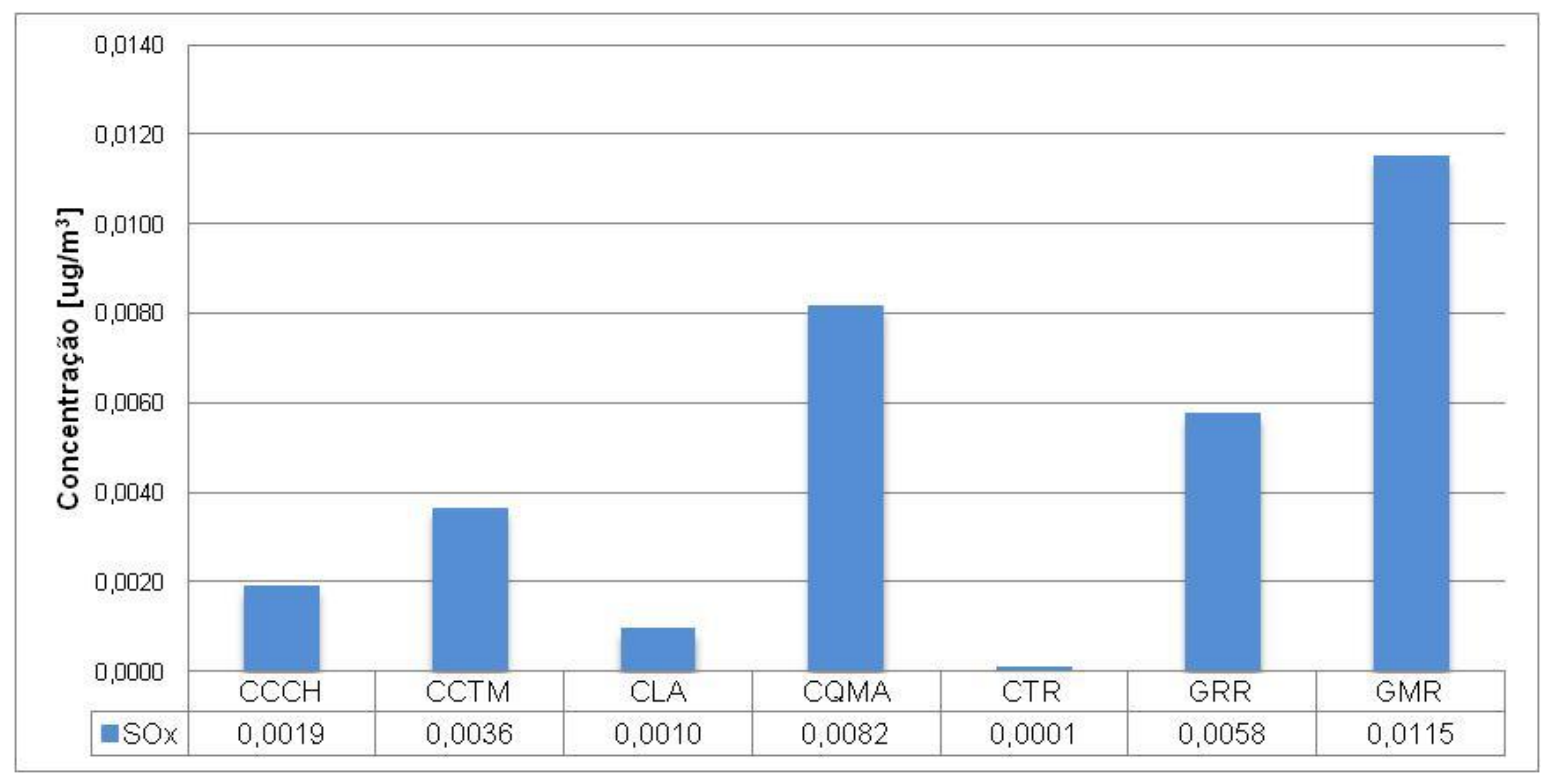

Para realizar a estimativa de cálculo da média aritmética foi utilizado como unidade de tempo 8 horas por dia, 05 dias por semana, sendo um total de operação de 40 horas semanais, considerando que todo o ácido utilizado nos processos analíticos fosse para a atmosfera como fonte de emissão.

Podemos observar, avaliando os resultados apresentados na Tabela 26, que todos os valores médios de $\mathrm{NO}_{\mathrm{x}}$ e $\mathrm{SO}_{\mathrm{x}}$ emitidos por hora determinados a partir da taxa de emissão atmosféricas das fontes fixas pertencentes aos Laboratórios dos Centros do IPEN se apresentaram muito abaixo dos valores estimados em comparação com legislação ambiental federal e estadual. 


\section{CONCLUSÃO}

Tendo em vista que o objetivo principal deste trabalho foi estabelecer estratégias para a gestão da qualidade do ar em empreendimentos de ensino, pesquisa e inovação, os resultados encontrados no trabalho mostram:

Os modelos de estimativas de fontes são aplicados para 0 licenciamento das atividades poluidoras, que depende da avaliação dos impactos causados pelo empreendimento e, geralmente, a metodologia de estimativa e de projeção de emissão da poluição é o único recurso para avaliar a emissão de empreendimentos, sendo considerada um ponto de partida para avaliações mais completas.

No Brasil, os principais instrumentos utilizados no controle da poluição do ar são os padrões de qualidade e os de emissão.

O inventário é uma ferramenta essencial para o conhecimento das consequências que as atividades humanas e seus processos possam causar na atmosfera, e servem de base para um processo de gerenciamento sustentável e para a definição das políticas de qualidade do ar bem como das ações a serem tomadas para minimização dos impactos quanto a alterações climáticas. Fornece a base de verificação do cumprimento e atendimento as legislações ambientais e as diretivas dos órgãos ambientais.

A metodologia de cálculo de emissões atmosféricas mais adequada a ser aplicada neste trabalho foi baseada nos critérios da EPA descritos na "Emissions Factors \& AP 42, Compilation of Air Pollutant Emission Factors. Essa metodologia possibilitou realizar um diagnóstico das emissões no campus do IPEN e a identificar os processos com emissões mais significativas.

O inventário de emissões de fontes fixas do IPEN foi realizado seguindo a metodologia da CETESB.

Foram inventariados os processos produtivos de todos os centros de pesquisa do IPEN, junto à caracterização e quantificação das fontes fixas dos Centros de Pesquisa e da Gerência de Segurança, totalizando 207 fontes 
(capelas de exaustão de gases, coifas e exaustores). As áreas com processos em maior escala possuem sistemas de remoção.

Para avaliação do grau de poluição ambiental foram adotados os níveis de referência descritos na Resolução CONAMA 03/90 e no Decreto Estadual № 59113/2013.

Quanto aos poluentes monitorados nos laboratórios do instituto, as concentrações encontram-se abaixo dos valores encontrados na Resolução CONAMA 03/1990 e no Decreto Estadual 59113/2013, mesmo levando em consideração no regime de 8 horas por dia e 5 dias semanais, em atendimento aos limites legais.

Desse modo, esse trabalho contribuiu para a implementação da gestão das emissões atmosféricas de fontes estacionárias nos laboratórios dos centros de pesquisas do IPEN e a elaboração do Programa de Monitoramento Atmosférico PMA-IPEN.

Este estudo possibilitou elaborar, de forma clara e simples, informações atualizadas ao nível do campus do IPEN, sobre as emissões atmosféricas de gases acidificantes (GA), precursores de ozônio, partículas em suspensão, metais pesados (MP) e gases com efeito de estufa (GEE). Os resultados possibilitaram fornecer informação de caráter geral sobre o Inventário de Emissões de Poluentes Atmosféricos no campus do IPEN em complementação ao programa de monitoramento de ar realizado em seu campus. Este estudo torna-se uma informação de base e uma ferramenta de apoio ao planejamento e gestão da qualidade do ar no campus e em atendimento as ações de licenciamento ambiental.

A partir deste procedimento será possível dar início a revisão e otimização de todos os processos existentes com o objetivo de identificar possíveis medidas mitigadoras para redução das emissões atmosféricas. 


\title{
FATOR DE EMISSÃO PARA O ÁCIDO NÍTRICO $\left(\mathrm{H}_{3} \mathrm{NO}_{4}\right)$
}

\author{
Table 8.8-1. NITROGEN OXIDE EMISSIONS FROM \\ NITRIC ACID PLANTS
}

EMISSION FACTOR RATING: E

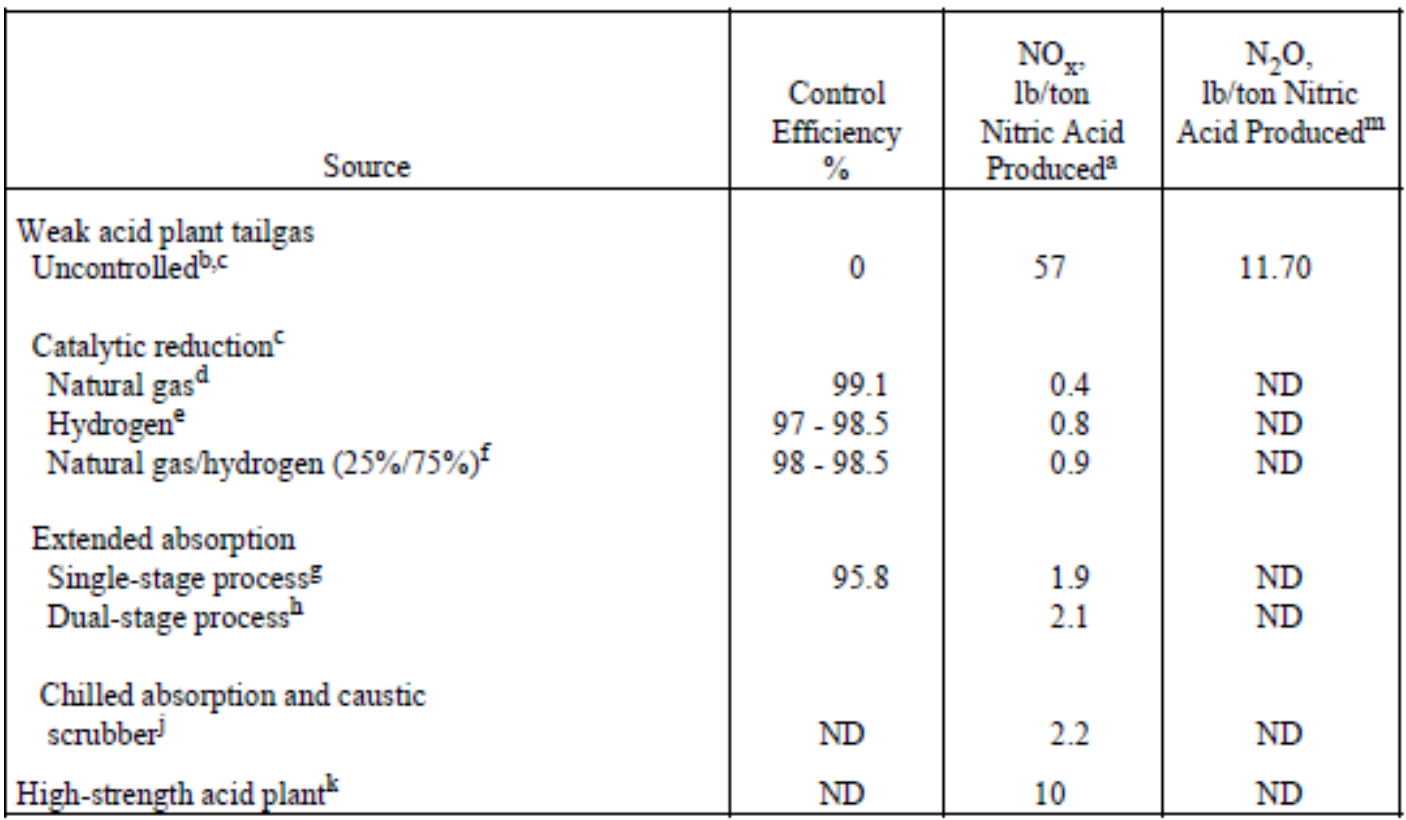

a Assumes $100 \%$ acid. Production rates are in terms of total weight of product (water and acid). A plant producing 500 tons per day of 55 weight $\%$ nitric acid is calculated as producing 275 tons/day of $100 \%$ acid. To convert $\mathrm{lb} /$ ton to $\mathrm{kg} / \mathrm{Mg}$, multiply by $0.5 . \mathrm{ND}=$ no data.

b Reference 6. Based on a study of 12 plants, with average production rate of 230 tons $\left(100 \% \mathrm{HNO}_{3}\right) /$ day (range $55-750$ tons) at average rated capacity of $97 \%$ (range $72-100 \%$ ).

c Single-stage pressure process.

d Reference 4. Fuel is assumed to be natural gas. Based on data from 7 plants, with average production rate of 340 tons $\left(100 \% \mathrm{HNO}_{3}\right)$ /day (range $55-1077$ tons).

e Reference 6. Based on data from 2 plants, with average production rate of 160 tons $\left(100 \% \mathrm{HNO}_{3}\right) /$ day (range $120-210$ tons) at average rated capacity of $98 \%$ (range $95-100 \%$ ). Average absorber exit temperature is $85^{\circ} \mathrm{F}$ (range $78-90^{\circ} \mathrm{F}$ ), and the average exit pressure is 85 psig (range 80 - 94 psig).

f Reference 6. Based on data from 2 plants, with average production rate of 230 tons $\left(100 \% \mathrm{HNO}_{3}\right)$ /day (range $185-279$ tons) at average rated capacity of $110 \%$ (range $100-119 \%$ ). Average absorber exit temperature is $91^{\circ} \mathrm{F}$ (range $83-98^{\circ} \mathrm{F}$ ), and average exit pressure is $79 \mathrm{psig}$ (range $79-80 \mathrm{psig}$ ).

8 Reference 4. Based on data from 5 plants, with average production rate of 540 tons $\left(100 \% \mathrm{HNO}_{3}\right) /$ day (range 210 - 1050 tons).

b Reference 4. Based of data from 3 plants, with average production rate of 590 tons $\left(100 \% \mathrm{HNO}_{3}\right) /$ day (range 315 - 940 tons).

i Reference 4. Based on data from 1 plant, with a production rate of 700 tons $\left(100 \% \mathrm{HNO}_{3}\right) /$ day.

${ }^{k}$ Reference 2. Based on data from 1 plant, with a production rate of 1.5 tons $\left(100 \% \mathrm{HNO}_{3}\right) /$ hour at $100 \%$ rated capacity, of $98 \%$ nitric acid.

m Reference 7 . 
Table 8.7-2 (English Units). EMISSION FACTORS FOR HYDROFLUORIC ACID MANUFACTURE $^{\mathrm{a}}$

EMISSION FACTOR RATING: E

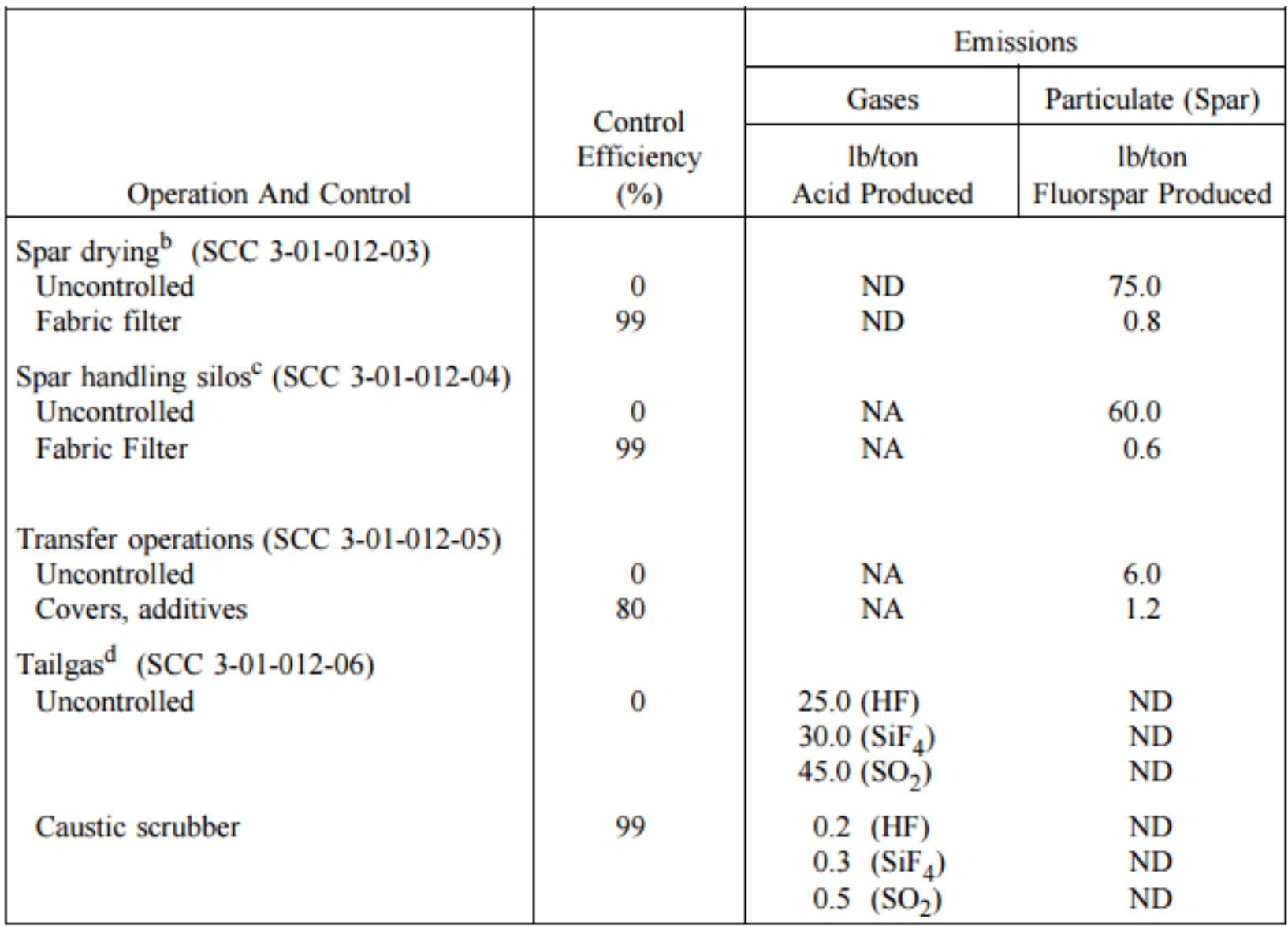

a $\mathrm{SCC}=$ Source Classification Code. $\mathrm{ND}=$ no data. $\mathrm{NA}=$ not applicable.

${ }^{\mathrm{b}}$ Reference 1. Averaged from information provided by 4 plants. Hourly fluorspar input calculated from reported 1975 year capacity, assuming stoichiometric amount of calcium fluoride and $97.5 \%$ content in fluorspar. Hourly emission rates calculated from reported baghouse controlled rates. Values averaged are as follows:

\begin{tabular}{ccr} 
Plant & 1975 HF Capacity (tons) & Emissions Fluors \\
\cline { 3 - 4 } 1 & 15,000 & 106 \\
2 & 20,000 & 130 \\
3 & 50,000 & 42 \\
4 & 11,000 & 30
\end{tabular}

${ }^{\mathrm{c}}$ Reference 1. Four plants averaged for silo emissions, 2 plants for transfer operations emissions.

${ }^{d}$ Three plants averaged from Reference 1 . Hydrogen fluoride and $\mathrm{SiF}_{4}$ factors from Reference 4 . 
FATOR DE EMISSÃO PARA O ÁCIDO CLORÍDRICO (HCl)

Table 8.6-1 (Metric And English Units). EMISSION FACTORS FOR HYDROCHLORIC ACID MANUFACTURE ${ }^{\mathrm{a}}$

EMISSION FACTOR RATING: E

\begin{tabular}{|c|c|c|}
\hline \multirow[b]{2}{*}{ Byproduct Hydrochloric Acid Process } & \multicolumn{2}{|c|}{$\mathrm{HCl}$ Emissions } \\
\hline & $\begin{array}{c}\mathrm{kg} / \mathrm{Mg} \\
\mathrm{HCl} \\
\text { Produced }\end{array}$ & $\begin{array}{c}\mathrm{lb} / \text { ton } \\
\mathrm{HCl} \\
\text { Produced }\end{array}$ \\
\hline With final scrubber (SCC 3-01-011-99) ${ }^{b}$ & 0.08 & 0.15 \\
\hline Without final scrubber (SCC 3-01-011-99) & 0.90 & 1.8 \\
\hline
\end{tabular}

${ }^{a}$ Reference 5. SCC $=$ Source Classification Code.

${ }^{b}$ This SCC is appropriate only when no other SCC is more appropriate. If $\mathrm{HCl}$ is produced as a byproduct of another process such as the production of dichloromethane, trichloroethane, perchloroethylene, or vinyl chloride then the emission factor and SCC appropriate for that process vent should be used.

\section{FATOR DE EMISSÃO PARA O ÁCIDO SULFÚRICO $\left(\mathrm{H}_{2} \mathrm{SO}_{4}\right)$}

Table \$.10-1 (Metric And English Units). \$ULFUR DIOXIDE EMIS\$IOIV FACTORS FOR SULFURIC ACID PLANTS ${ }^{3}$

EMISSION FACTOR RATING: E

\begin{tabular}{|c|c|c|c|}
\hline \multirow{2}{*}{\multicolumn{2}{|c|}{$\begin{array}{c}\mathrm{SO}_{2} \mathrm{To} \mathrm{SO}_{3} \\
\text { Conversion Efficiency } \\
(\%)\end{array}$}} & \multicolumn{2}{|c|}{$\mathrm{SO}_{2}$ Emissions $^{\mathrm{b}}$} \\
\hline & & \multirow{2}{*}{$\frac{\mathrm{kg} / \mathrm{Mg} \text { of Product }}{48.0}$} & \multirow{2}{*}{$\frac{\mathrm{Ib} \text { ton Of Product }}{96}$} \\
\hline 93 & $(\mathrm{SCC} 3=01=023=18)$ & & \\
\hline 94 & $(\mathrm{SCC} 3-01-023-16)$ & 41.0 & 82 \\
\hline 95 & (SCC 3-01-023-14) & 35.0 & 70 \\
\hline 96 & $\left(\$ C C^{3}-01-023-12\right)$ & 27.3 & 35 \\
\hline 97 & (SCC 3-01-023-10) & 20.0 & 40 \\
\hline 98 & $(\mathrm{SCC} 3-01=023-\mathrm{CB})$ & 13.0 & 26 \\
\hline 99 & (SCC 3-01-023-C6) & 7.0 & 14 \\
\hline อิ & (8CC 3-ó1-023-04) & 3.5 & 7 \\
\hline 99.7 & $\mathrm{NA}$ & 20 & 4 \\
\hline 100 & $(S C C 3-01=023-01)$ & 0,0 & 0,0 \\
\hline
\end{tabular}

Referenee 3, $\$ \mathrm{CC}=$ \$ouree Classifieation Code, NA = not applieable

b This linear interpolation formula can be used for calculating emission factors for conversion efficiencies between 93 and $100 \%$ : emission factor $(\mathrm{kg} / \mathrm{Mg}$ of Product $)=682-6.82(\%$ conversion efficiency) (emission fastor [1b/ton of Product $]=1365-13.65$ [\% conversion efficiency]). 
APÊNDICE B

Mapa de localização dos prédios referentes aos Centros ou unidades administrativas do IPEN

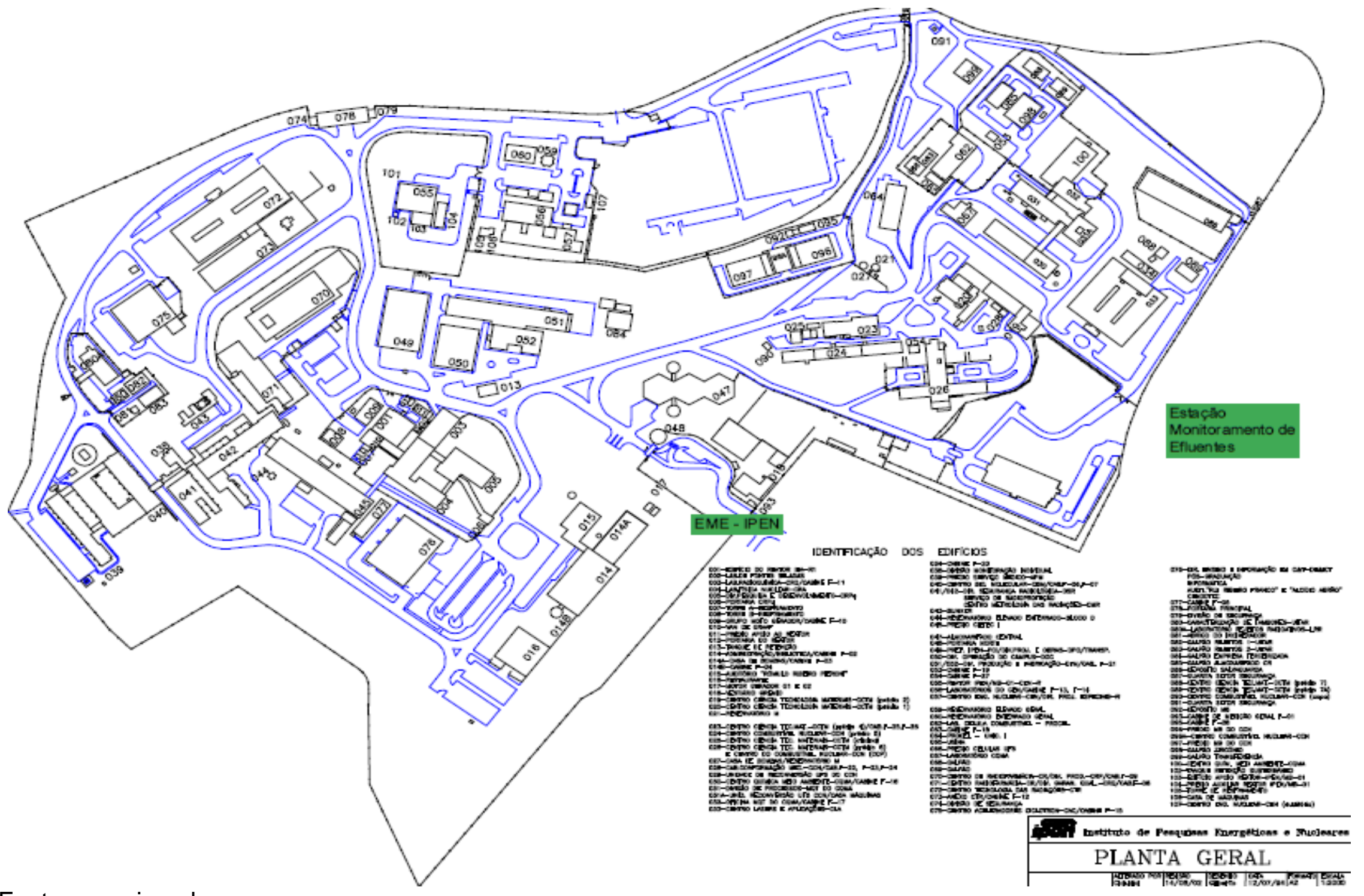

Fonte: www.ipen.br.

मकास 


\section{APÊNDICE C}

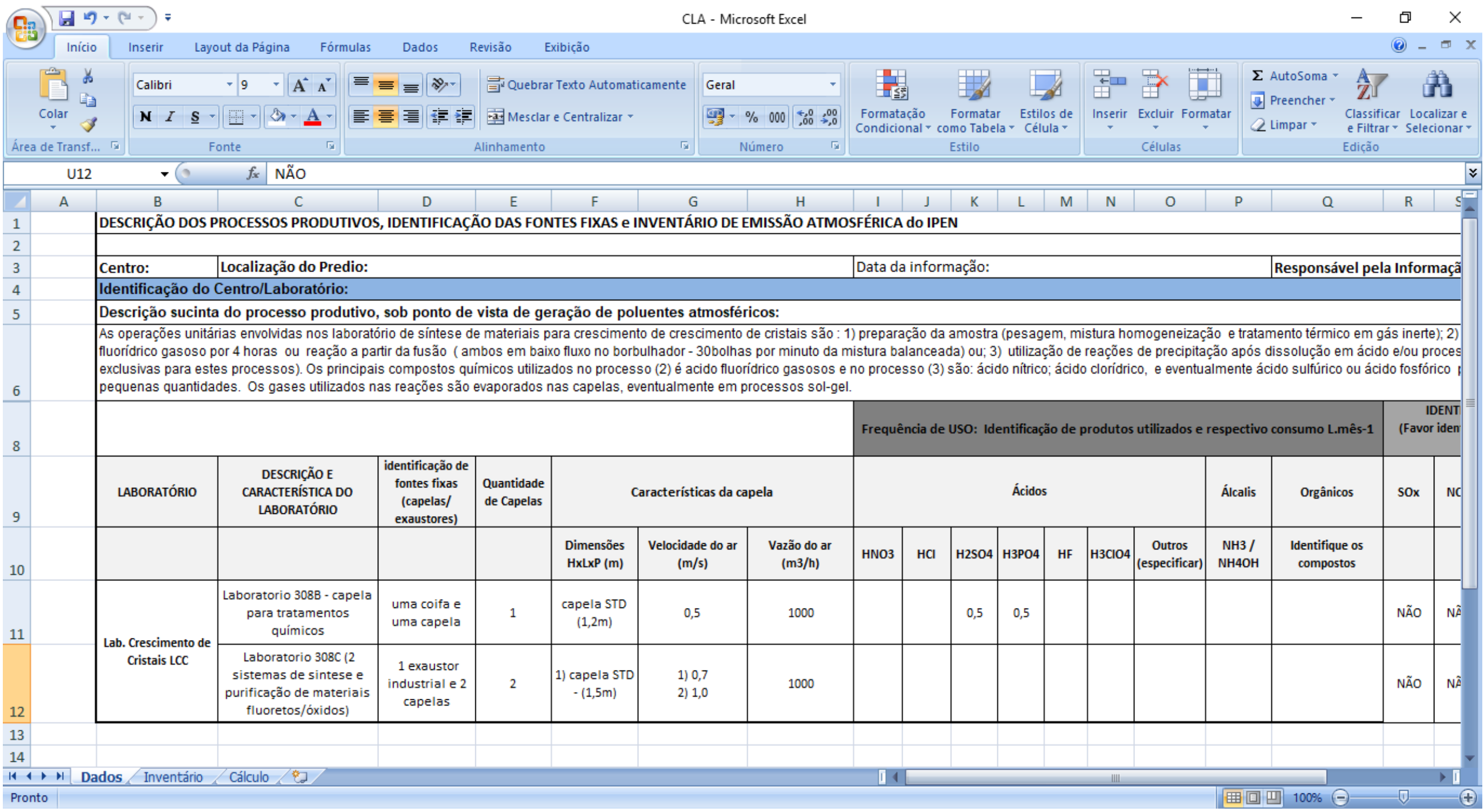




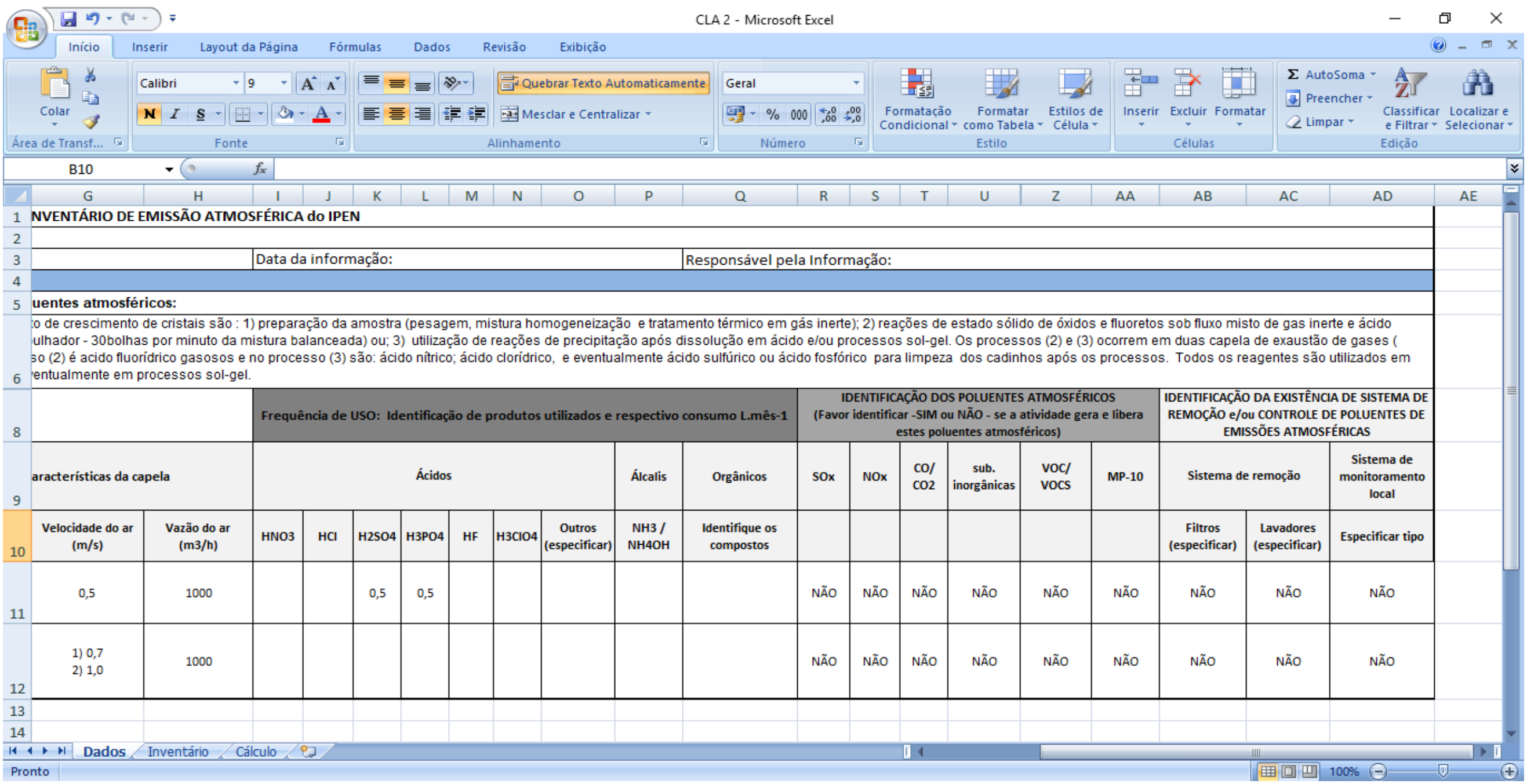




\section{REFERÊNCIAS BIBLIOGRÁFICAS}

BAKONYI, Sonia M. C.; Inês DANNI-OLIVEIRA M.; MARTINS, Lourdes Conceição; BRAGA, Alfésio. 2004. Air pollution and respiratory diseases among children in the city of Curitiba, Brazil. Disponível em: < http://www.scielo.br/scielo.php?script=sci_arttext\&pid=S0034-

$89102004000500012 \&$ Ing=en\&nrm=iso\&tIng=en>. Acesso em 16 de mar. 2016.

BRASIL. Lei Estadual n 997, de 31 de maio de 1976. Dispões sobre o Controle da Poluição do Meio Ambiente. Disponível em:<http://www.ambiente.sp.gov.br/> Acesso em: 19 de março 2015.

BRASIL. Decreto Estadual n ${ }^{\circ}$ 59113, de 23 de abril de 2013. Estabelece Novos Padrões de Qualidade do $\operatorname{Ar}$ e dá providências correlatas. Disponível em:<https://www.al.sp.gov.br/repositorio/legislacao/decreto/2013/decreto-5911323.04.2013.html> Acesso em: 19 de março 2015.

BRASIL. Lei Federal n 6938, de 31 de agosto de 1981. Dispões sobre a Política Nacional do Meio Ambiente. Disponível em: < http://www.mma.gov.br/port/conama/legiabre.cfm?codlegi=313> Acesso em: 19 de março 2015.

BRASIL. Ministério do Meio Ambiente - MMA. Qualidade do Ar. Poluentes Atmosféricos. Disponível em: http://www.mma.gov.br/cidadessustentaveis/qualidade-do-ar/poluentes-atmosf\%C3\%A9ricos. Acesso em: 15 jul. 2016.

BRASIL. Ministério do Trabalho e Emprego - MTE. NR 15 de 08 de junho de 1978. Atividades e Operações Insalubres. Diário Oficial [da] República Federativa do Brasil, Brasília, DF, 06 jul. 1978. Disponível em:<http://trabalho.gov.br/seguranca-e-saude-no-trabalho/normatizacao/normasregulamentadoras/norma-regulamentadora-n-15-atividades-e-operacoes- insalubres>. Acesso em: 17 mar.2015.

BRASIL. Resolução CONAMA 03, de 28 de junho de 1990. Dispõe sobre padrões de qualidade do ar, previstos no PRONAR. Ministério do Meio Ambiente. Brasília, DF, 22 ago. 2008. Disponível em < http://www.mma.gov.br/port/conama/legiabre.cfm?codlegi=100>. Acesso em 18 de fev. 2015.

BRASIL. Resolução CONAMA 08, de 06 de dezembro de 1990. Dispõe sobre o estabelecimento de limites máximos de emissão de poluentes no ar para processos de combustão externa de fontes fixas de poluição. Ministério do Meio Ambiente. Brasília, DF, 28 dez. 1990. Disponível em < http://www.mma.gov.br/port/conama/res/res90/res0890.html >. Acesso em 18 de fev. 2015.

BRASIL. Resolução CONAMA 382, de 26 de dezembro de 2006. Estabelece os limites máximos de emissão de poluentes atmosféricos para fontes fixas. Ministério do Meio Ambiente. Brasília, DF, 2 jan. 2007. Disponível em < http://www.mma.gov.br/port/conama/legiabre.cfm?codlegi=520>. Acesso em 18 
de fev. 2015.

BRASIL. Resolução CONAMA 436, de 22 de dezembro de 2011. Estabelece os limites máximos de emissão de poluentes atmosféricos para fontes fixas instaladas ou com pedido de licença de instalação anteriores a 02 de janeiro de 2007. Ministério do Meio Ambiente. Brasília, DF, 26 dez. 2011. Disponível em < http://www.mma.gov.br/port/conama/legiabre.cfm?codlegi=660>. Acesso em 18 de fev. 2015.

CANÇADO, José Eduardo D.; BRAGA, Alfésio; PEREIRA, Luiz Alberto A.; ARBEX, Marcos A.; SALDIVA, Paulo H. N.; SANTOS, Ubiratan de Paula. 2006. Clinical repercussions of exposure to atmospheric pollution. Trabalho realizado no Laboratório de Poluição Atmosférica do Departamento de Patologia da Faculdade de Medicina da Universidade de São Paulo - FMUSP - São Paulo (SP) Brasil. Disponível em: <http:// http://www.scielo.org/php/index.php>. Acesso em 16 de fev. 2016.

CAVALCANTI, Paulina Maria P. S. MODELO DE GESTÃO DA QUALIDADE DO AR - ABORDAGEM PREVENTIVA E CORRETIVA. 2010. Tese (Doutorado). Universidade do Rio de Janeiro, Rio de Janeiro.

COMISSÃO de COORDENAÇÃO e DESENVOLVIMENTO REGIONAL de LISBOA e VALE do TEJO (CCDR-LVT). Vitor Gois, Pedro Torres, Luisa Nogueira, Hugo Maciel e Cristina Almeida. Inventário de Emissões Atmosféricas da Região de Lisboa e Vale Do Tejo 2000-2001. POR, 2006.Disponível em: http://www.ccdr- Ivt.pt/files/3c9e2c6c6627ffc1cd69f17e24b92a6c.pdf. Acesso em: 30 out. 2015.

COMPANHIA AMBIENTAL DO ESTADO DE SÃO PAULO (CETESB). Inventário de Emissões das Fontes Estacionárias do Estado de São Paulo - Manual de Preenchimento. São Paulo, novembro de 2009. Disponível em:<http://sistemasinter.cetesb.sp.gov.br/inventariofontes/Manual_de_Preenchim ento.pdf> Acesso em: 10 de fevereiro de 2016.

COMPANHIA AMBIENTAL DO ESTADO DE SÃO PAULO №010/2010/P de 12 de janeiro de 2010. Dispõe sobre o Monitoramento de Emissões de Fontes Fixas de Poluição do Ar no Estado de São Paulo - Termo de Referência para a Elaboração do Plano de Monitoramento de Emissões Atmosféricas (PMEA). São Paulo. Brasília, DF, 15 de jan.2010. CETESB. Disponível em < http://www.cetesb.sp.gov.br/wpcontent/uploads/sites/11/2013/11/DD_010_DO.pdf>. Acesso em 15/03/2015.

COMPANHIA AMBIENTAL DO ESTADO DE SÃO PAULO (CETESB). Inventário de emissões antrópicas de gases de efeito estufa diretos e indiretos do Estado de São Paulo, 2a $2^{\text {a }}$ Ed. São Paulo, 2011. Disponível em: $<$ http://inventariogeesp.cetesb.sp.gov.br/wpcontent/uploads/sites/30/2014/01/Primeiro_Inventario_GEE_WEB_SegundaEdicao-v1.pdf> Acesso em: 15 de junho de 2015

COMPANHIA AMBIENTAL DO ESTADO DE SÃO PAULO (CETESB). Relatório de Qualidade do Ar no Estado de São Paulo. 2015; Série Relatórios. 
Disponível em: <http://ar.cetesb.sp.gov.br/publicacoes-relatorios/>. Acesso em: 17 de jun 2015.

COMPANHIA AMBIENTAL DO ESTADO DE SÃO PAULO (CETESB). Qualidade do Ar. Padrões, índices. Disponível em: <http://sistemasinter.cetesb.sp.gov.br/Ar/ar_indice_padroes.mtc.aspAcesso em: 15 de jun. de 2015.

Comissão Nacional de Energia Nuclear (CNEN). Plano de Gestão de logística sustentável - LS. 2013. Disponível em: < http://www.cnen.gov.br/images/cnen/documentos/publicacoes/Plano-Gestao- LogSust-CNEN.pdf>. Acesso em: 25 de mar. 2015.

EEA - (EUROPEAN ENVIRONMENT AGENCY). EMEP/EEA Air Pollutant Emission Inventory Guidebook 2013. Technical guidance to prepare national emission inventories. $\mathrm{N}^{\circ}$ 12, 2013. Disponível em: < file://C:/Users/grsantos/Downloads/1.\%20EMEP-

EEA\%20air\%20pollutant\%20emission\%20inventory\%20guidebook\%20\%202013.pdf> Acesso em: 18 de mar. 2015.

EEA - (EUROPEAN ENVIRONMENT AGENCY). Mitigação dos efeitos das alterações climáticas. 2008. Disponível em: < https://www.eea.europa.eu/downloads/96e7dcfb662ac633a24fe61a83a0e94d/148 6131881/intro.pdf>. Acesso em: 13 jul.2017.

\section{EPA - (ENVIRONMENTAL PROTECTION AGENCY). Compilation of}

Air Pollutant Emission Factors, AP-42, Fifth Edition, Introduction, janeiro de $1995 . \quad$ Disponível em: <http:// https://www3.epa.gov/ttn/chief/ap42/oldeditions/5th_edition/ap42_5thed_orig.pdf> . Acesso em: 12 abr. 2015.

EPA - (ENVIRONMENTAL PROTECTION AGENCY). Handbook for criteria Pollutant Inventory Development: A Beginner's Guide for Point and Area Sources. , 1999. Disponível em: < https://www.epa.gov/ >. Acesso em 13 abr. 2015.

EPA - (ENVIRONMENTAL PROTECTION AGENCY) Introduction to the Emission Inventory Improvement Program. Technical Report Series, v.1.United States of America, 1997. Disponível em: <http:// https://www.epa.gov/sites/production/files/2015- 08/documents/i01.pdf>. Acesso em 13 abr. 2015.

EPA - (ENVIRONMENTAL PROTECTION AGENCY). Compilation of Air Pollutant Emission Factors, v.1: Stationary Point and Area Sources. Chapter 3: Stationary Internal Combustion Sources. 5th Edition, United States of America, 2000. Disponível em: <http://

https://www3.epa.gov/ttn/chief/ap42/ch03/index.html>. Acesso em 13 abr. 2015.

EPA - (ENVIRONMENTAL PROTECTION AGENCY). Introduction to Stationary Point Source Emission Inventory Developmen. Emission Inventory Improvement Program - Technical Report Series, v.2, cap. 1, United States of America, 2001. Disponível em: <http:// 
http://www.dep.wv.gov/daq/planning/inventory/Documents/EIIP\%20V02\%20Ch01 \%20Intro\%20to\%20Point\%20Source\%20El\%20Development.pdf>. Acesso em 13 abr. 2015.

EPA (ENVIRONMENTAL PROTECTION AGENCY).EmissionInventory Improvement Program. Volume II: Introduction to the Stationary Point Source Emission Inventory Development. Maio de 2011. Disponível em: < http://www.dep.wv.gov/daq/planning/inventory/Documents/EIIP\%20V02\%20Ch01 \%20Intro\%20to\%20Point\%20Source\%20El\%20Development.pdf>. Acesso em: 19 abr. 2015.

EPA (213b), U. S. Environmental Protection Agency - Bubble concept, Disponível em: <http://www.epa.gov>. Acesso em: 14 abr. 2017.

EPA

(ENVIRONMENTAL PROTECTION AGENCY).

Overview of the Clean Air Act and Pollution. Disponível em: < https://www.epa.gov/clean-air-act-overview>. Acesso em: 19 abr. 2017.

GOUVEIA, Nelson. Saúde e Meio Ambiente nas cidades: Os desafios da saúde ambiental.1999. São Paulo. Disponível em:

<http:// http://www.scielo.br/scielo.php?script=sci_arttext\&pid=S0104$12901999000100005>$. Acesso em 16 de fev. 2016.

GUARIEIRO, Lílian Lefol Nani; GUARIEIRO, Aline Lefol Nani. Vehicles emissions: What will change with the se of biofuel? In: FANG, Z. (Ed.). Biofules Economy, Environment and Sustainability, 2013.Disponível em: <http:// http://www.intechopen.com/books/biofuels-economyenvironment-and- sustainability/vehicle-emissions-what-will-change-with-use-ofbiofuel->. Acesso em 18 de mar. 2016.

INTERGOVERNMENTAL PANEL ON CLIMATE CHANGE (IPCC).Climate Change 2013. Summary for Policymakers.Disponível em: $<\quad$ https://www.ipcc.ch/pdf/assessmentreport/ar5/wg1/WGIAR5_SPM_brochure_en.pdf>. Acesso em: 26 abr. 2015.

LIMA, João Filipe Barroso Lima. Quantificação de Emissões Atmosféricas na Indústria de Painéis de Derivados de Madeira 2009. Tese (Mestrado). Universidade de Porto. Portugal.

LISBOA, H. M.; KAWANO, M. Controle da Poluição Atmosférica Monitoramento de Poluentes Atmosféricos. 1. Versão. Montreal, 2007.

LI, L., CHEN, C.H., FU, J.S., HUANG, C., STREETS, D.G., HUANG, H.Y., ZHANG, G.F., WANG, Y.J., JANG, C.J., WANG, H.L., CHEN, Y.R., FU, J.M.,. Air quality and emissions in the Yangtze River Delta, China. Atmos. Chem. Phys, v.11, pp 1621-1639, 2011. Disponível em:< http://www.atmos-chemphys.net/11/1621/2011/>. Acesso em: 3 de mar.2016. 
KALNAY, E. CAI, M., 2003. Impact of urbanization and land-use change on climate. Nature 423, 528-531. Disponível em: <http:// http://www.nature.com/nature/journal/v423/n6939/full/nature01675.html>. Acesso em: 15 de jan.2016.

KAWASHIMA, A.B.; MORAIS, M.V.B. de, MARTINS, L.D.; URBINA, V.;RAFEE, S.A. A.; CAPUCIM, M.N.; MARTINS, J.A. Journal of Geoscience andEnvironment Protection, 2015, 3, 72-76,2015.Disponível em: $<$ http:// http://www.utfpr.edu.br/londrina/cursos/mestradosdoutorados/Ofertados-neste- Campus/mestrado-academico-em-engenhariaambiental/producao- cientifica/2015/kawashima-a-b-morais-m-v-b-de-martins-l-durbina-v-rafee-s-a-a- capucim-m-n-martins-j-a-estimates-and-spatial-distributionof-emissions-from- sugar-cane-bagasse-fired-thermal-power-plants-in-brazil-3-7276/view>. Acesso em: 20 de nov.2015.

OLIVEIRA, J. L. F. Poluição atmosférica e o transporte rodoviário: Perspectivas de Uso do Gás Natural na Frota de Ônibus Urbanos da Cidade do Rio de Janeiro. 1997. Tese (Doutorado). Sc., COPPE/Universidade Federal do Rio de Janeiro, Rio de Janeiro.

ONU. (2015). "Novo relatório da ONU associa mudanças climáticas a direitos humanos". Disponível em: <http://web.unep.org/novo-relat\%C3\%B3rio-da-onuassocia-mudan\%C3\%A7as-clim\%C3\%A1ticas-direitos-humanos>. Acesso em: 28 out. 2017.

ONU. (2017). "Seminário discute mudança do clima, erradicação da pobreza e desenvolvimento humano." Brasil, 2017. Disponível em: < https://nacoesunidas.org/seminario-discute-mudanca-do-clima-erradicacao-dapobreza-e-desenvolvimento-humano/>. Acesso em: 28 out. 2017.

PIRES, DILSON O. Inventário de Emissões Atmosféricas de Fontes Estacionárias e sua Contribuição para a poluição do ar na região metropolitana do Rio de Janeiro. 2005. Tese (Mestrado). Universidade Federal do Rio de Janeiro, Rio de Janeiro.

Pires, Maria. Aparecida. F.; Cotrim, Marycel Elena B.; SOUSA, W. H. de. Relatório Anual de Gestão Ambiental. São Paulo: IPEN/CNEN-SP. 2016 e 2017.

PNUD. 2014. Synthesis report of the Secretary-General on the post-2015 sustainable development agenda. 34 p. Disponível em: http://www.pnud.org.br/arquivos/relatorio_sintese_ods.pdf $\quad$ Acesso em 15/03/2015.

SOUZA, EDMILSON de. Inventário de Emissões Atmosféricas e Avaliação de Condicionantes Meteorológicas: Estudo de Caso Três Lagoas. 2009.Tese (Doutorado). Escola de Engenharia de São Carlos. Universidade de São Paulo, São Paulo.

STERN, A. C.;BOUBEL, R. W.; TURNER, D. B.; FOX, D. L.,1984,Fundamentals of Air Pollution, Academic Press, Inc., Orlando, Florida. 
UNECE - United Nations Economic Comission for Europe. 1979 Convention on Long-Range Transboundary Air Pollution. Disponível em: < http://www.unece.org/env/lrtap/welcome.html >. Acesso em: 18 de mar.2015.

QIU, P., TIAN H., ZHU, C., LIU, K., GAO, J., ZHOU, J. An elaborate high resolution emission inventory of primary air pollutants for the Central Plain Urban Agglomeration of China. Atmospheric Environment , v.86, pp 93-101, 2014.

SANTOS, Camila F. R. T. T., SILVA, Tatiane B. de S. C., COTRIM, Marycel Helena B., PIRES, Maria Aparecida F. FATORES DE EMISSÃO ATMOSFÉRICA E ANÁLISE DE SIGNIFICÂNCIA APLICADA NA GESTÃO DA QUALIDADE DO AR NO CAMPUS DO IPEN/CNEN-SP. Disponível em: < http://engemausp.submissao.com.br/18/anais/arquivos/480.pdf>. Acesso em: 13 mai. 2017.

UK NAEI, National Atmospheric Emissions Inventory; AQPI Summary Report Emissions of Air Quality Pollutants - 1990-2014. Departament for Evironment, Food \& Rural Affairs. Disponível em:< https://ukair.defra.gov.uk/assets/documents/reports/cat07/1609130906_NAEI_AQPI_Sum $\mathrm{m}$ ary_Report_1990-2014_Issue1.1.pdf >. Acesso em: 30 out. 2015.

WANG, Y. The analysis of the impacts of energy consumption on environment and public health in China. Energy, v. 35, n. 11, p. 4473-4479, 2010. Disponível em:<http://www.sciencedirect.com/science/article/pii/S0360544209001273>. Acesso em: 20 nov. 2015.

World Health Organization (WHO). WHO Air Quality Guidelines Global Update. 2005. Report on a working group meeting, Boon, Germany. Disponível em: <http://www.who.int. Acesso em: 27 nov. 2015. 